UNIVERSIDADE DE SÃO PAULO

INSTITUTO DE RELAÇÕES INTERNACIONAIS - IRI

PROGRAMA DE PÓS-GRADUAÇÃO EM RELAÇÕES INTERNACIONAIS

BRUNA ELOY DE AMORIM

A IMPORTÂNCIA DAS NATIONAL OIL COMPANIES PARA AS RELAÇÕES INTERNACIONAIS CONTEMPORÂNEAS: UM ESTUDO DE CASO DA GAZPROM

SÃO PAULO 


$$
\text { UNIVERSIDADE DE SÃO PAULO }
$$

INSTITUTO DE RELAÇÕES INTERNACIONAIS - IRI

PROGRAMA DE PÓS-GRADUAÇÃO EM RELAÇÕES INTERNACIONAIS

\section{A IMPORTÂNCIA DAS NATIONAL OIL COMPANIES PARA AS RELAÇÕES INTERNACIONAIS CONTEMPORÂNEAS: UM ESTUDO DE CASO DA GAZPROM}

BRUNA ELOY DE AMORIM

Dissertação apresentada ao Programa de PósGraduação em Relações Internacionais do Instituto de Relações Internacionais da Universidade de São Paulo, para a obtenção do título de Mestre em Relações Internacionais.

Orientador: Prof. Dr. Feliciano Sá Guimarães Co-orientador: Prof. Dr. Edmilson Moutinho dos Santos 


\section{AGRADECIMENTOS}

Ao Instituto de Relações Internacionais da Universidade de São Paulo (IRI-USP) pela oportunidade de realizar meu curso de mestrado e pela excelência de seu corpo docente e funcionários.

Ao meu orientador, Prof. Dr. Feliciano de Sá Guimarães, e ao meu co-orientador, Prof. Dr. Edmilson Moutinho dos Santos, pelos comentários, críticas, correções e, principalmente, pela confiança no meu trabalho.

Aos meus pais, Ivan e Wilma, e aos meus irmãos, Paulo Emílio, Mariana e Gregório, pelo amor e carinho.

Aos meus demais familiares, particularmente ao Danilo, que me ajudou com as imagens e os mapas dessa dissertação.

Aos amigos e aos colegas do IRI, em especial à Eliceli Bonan, com quem dividi dúvidas, frustrações e conquistas ao longo do curso.

Especialmente ao Marcelo, meu marido, a quem dedico este trabalho. Seu apoio, compreensão e incentivos foram fundamentais para que eu pudesse chegar à conclusão dessa dissertação. 


\section{LISTA DE FIGURAS}

Figura 1 - Gráfico da Média Anual dos Preços do Petróleo de 1973 a 1989

Figura 2 - Gráfico de Comparação dos Preços do Petróleo e do Gás

Figura 3 - Mapa das Principais Regiões Produtoras de Gás na Rússia

Figura 4 - Mapa dos Principais Gasodutos Ligando a Rússia à Europa

Figura 5 - Gráfico dos Preços Spot (Brent/FOB) de 1990 a 2015

Figura 6 - Gráfico da Variação do Produto Nacional Russo de 1990 a 2015

Figura 7 - Gráfico dos Principais Clientes da Gazprom na Europa (incluindo Turquia)

Figura 8 - Mapa do Gasoduto Blues Stream e Provável Rota do Gasoduto Nabucco 


\section{LISTA DE ABREVIATURAS E SIGLAS}

ABM - Anti-Ballistic Missile Treaty

AGIP - Azienda Generale Italiana Petroli

ARAMCO - Arabian American Oil Company

BCF - Billion Cubic Feet

BMC - Bilhões de Metros Cúbicos

BP - British Petroleum

BRICS - Brasil, Rússia, Índia, China e África do Sul

BTC - Baku-Tbilisi-Ceyhan

BTE - Baku-Tbilisi-Erzurum

CEI - Comunidade dos Estados Independentes

CEE - Comunidade Econômica Europeia

CFE - Conventional Forces Europe Treaty

CFIUS - Committee on Foreign Investment in the United States

CFP - Compagnie Française des Pétroles

CIA - Central Intelligence Agency

CNOOC - China National Offshore Oil Corporation

CNUMAH - Conferência das Nações Unidas sobre Meio Ambiente Humano

CNPC - China National Petroleum Company

ECT - Energy Charter Treaty

EIA - Energy Information Administration

ENI - Ente Nazionali Idrocarburi

ERM - Emergency Response Mechanism

ESPO - East Siberia-Pacific Ocean

EUA - Estados Unidos da América

FMI - Fundo Monetário Internacional

FOB - Free on Board

FSB - Federalnaya Sluzhba Bezopasnosti

G7 - Grupo dos sete países mais industrializados

G8 - Grupo dos sete países mais industrializados, mais a Rússia

G20 - Grupo das vinte maiores economias do mundo

GATT - General Agreement on Tariffs and Trade

GECF - Gas Exporting Country Forum 
GNL - Gás Natural Liquefeito

IEA - International Energy Agency

IEF - International Energy Forum

IOCs - International Oil Companies

IPC - Iraqi Petroleum Company

IPE - International Petroleum Exchange

KGB - Komitet Gosudarstvennoi Bezopasnosti

OBOR - One Belt One Road

OCDE - Organização de Cooperação e Desenvolvimento Econômico

OCX - Organização de Cooperação de Xangai

OMC - Organização Mundial do Comércio

OMV - Österreichische Mineralölverwaltung

ONG - Organização Não Governamental

ONU - Organização das Nações Unidas

OSCE - Organização para Segurança e Cooperação na Europa

OTAN - Organização do Tratado do Atlântico Norte

OTSC - Organização do Tratado de Segurança Coletiva.

OPEP - Organização dos Países Exportadores de Petróleo

MAP - Membership Action Plan

NBD - Novo Banco de Desenvolvimento

NEP - Novaya Ekonomiceskaya Politika

NIOC - National Iranian Oil Company

NIS - Naftna Industrija Srbije

NOCs - National Oil Companies

NYMEX - New York Mercantile Exchange

PCA - Partnership and Cooperation Agreement

PdVSA - Petróleos de Venezuela Sociedad Anónima

PEMEX - Petróleos Mexicanos

PJC - NATO-Russia Permanent Joint Council

RDA - República Democrática Alemã

RFA - República Federal Alemã

SOCAL - Standard Oil of California

SORT - Strategic Offensive Reductions Treaty

START - Strategic Arms Reduction Treaty 
TANAP - Trans Anatolia Pipeline

TAP - Trans Adriatic Pipeline

TEXACO - Texas Oil Company

TMC - Trilhões de Metros Cúbicos

TNP - Tratado de Não Proliferação de Armas Nucleares.

TPC - Trilhões de Pés Cúbicos

URSS - União das Repúblicas Socialistas Soviéticas

UE - União Europeia

WTI - West Texas Intermediate

YPF - Yacimientos Petrolíferos Fiscales

YPFB - Yacimientos Petrolíferos Fiscales de Bolívia 


\section{SUMÁRIO}

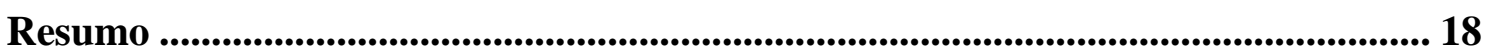

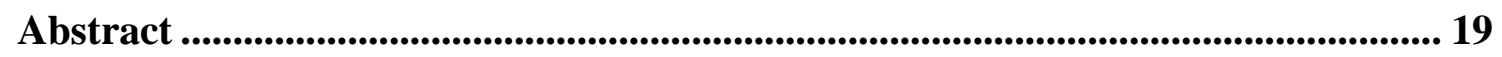

INTRODUÇÃ

10 Mercado Mundial de Hidrocarbonetos ................................................................. 14

1.1 O Surgimento das NOCs e sua Importância nas Relações Internacionais............. 14

1.2 As Particularidades do Mercado de Gás .............................................................. 32

2 Petróleo e Gás na Rússia e a Construção da Gazprom ............................................... 39

2.1 A Inserção da Rússia no Mercado Mundial de Energia......................................... 39

2.2 A Expansão do Mercado de Gás e a Criação da Gazprom .................................... 41

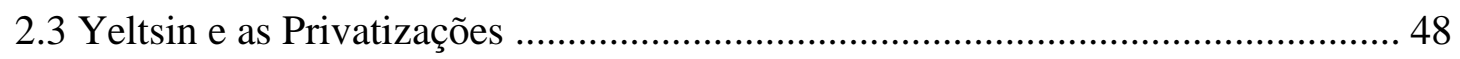

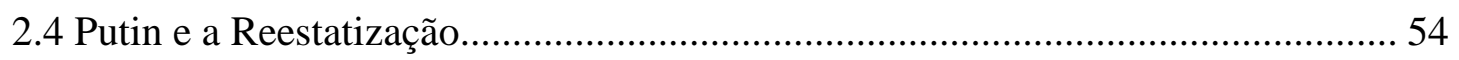

3 O Mercado do Gás e a Atuação Internacional da Gazprom .................................... 64

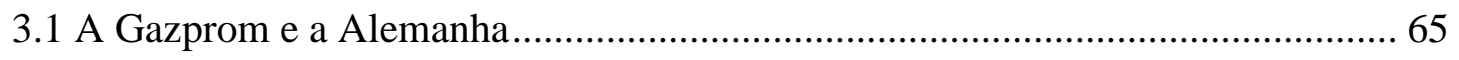

3.2 A Gazprom e a Ucrânia..................................................................................... 76

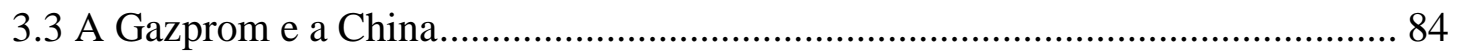

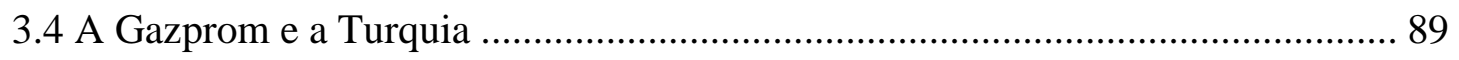

CONCLUSÃO

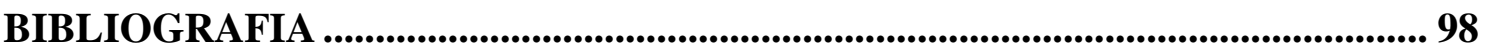




\title{
A IMPORTÂNCIA DAS NATIONAL OIL COMPANIES PARA AS RELAÇÕES INTERNACIONAIS CONTEMPORÂNEAS: UM ESTUDO DE CASO DA GAZPROM
}

\begin{abstract}
Resumo
O controle sobre recursos naturais como o petróleo e o gás representa um aspecto de fundamental importância no relacionamento entre países. Sendo majoritariamente controlada pelo Estado, o gerenciamento que as National Oil Companies (NOCs) fazem desses recursos possibilita sua utilização como uma ferramenta de política externa. Com o aumento dos preços dos hidrocarbonetos no mercado internacional a partir de 2000, o restabelecimento das NOCs passou a constituir uma nova possibilidade para se projetar poder em âmbito global.

Nesse contexto, buscou-se, neste trabalho, analisar a eficácia da atuação da principal NOC russa, a Gazprom, para a política externa de Moscou. Para tanto, foram investigadas as relações da Rússia com quatro países: Alemanha, Ucrânia, China e Turquia. A conclusão é a de que a operacionalização da Gazprom pelo governo russo tem gerado resultados positivos para o país, ainda que tais resultados não alcancem todos os casos.

Verificou-se que, em diferentes níveis, Alemanha, China e Turquia têm evitado contrapor-se diretamente a Moscou, sendo a Alemanha o caso mais significativo. A forte dependência da economia alemã do gás natural russo tem mitigado uma postura hostil em relação a Moscou, independentemente do partido que esteja à frente do governo alemão. No caso da China, a dependência dos hidrocarbonetos russos também desempenha um papel importante na relação bilateral, embora outros interesses, ademais de questões energéticas, constituam igualmente fatores de aproximação e convergência. Em relação à Turquia, embora a dependência energética dos recursos russos seja também significativa, a localização estratégica do território turco tem permitido a Ancara barganhar vantagens econômicos junto a Moscou, abrandando, em certa medida, o poder da Gazprom. A Ucrânia, por fim, é um caso claramente dissonante: mesmo com a forte dependência deste país do gás natural russo, a política externa de Kiev tem assumido posturas manifestadamente contrárias aos interesses de Moscou.
\end{abstract}


Palavras-chave: NOCs, Gazprom, política externa, Rússia, energia, gás natural.

\title{
THE IMPORTANCE OF NATIONAL OIL COMPANIES FOR CONTEMPORARY INTERNATIONAL RELATIONS: A CASE STUDY OF GAZPROM
}

\begin{abstract}
Control over natural resources such as oil and gas constitutes an aspect of fundamental importance in the relationship among countries. Being mostly controlled by the state, through National Oil Companies (NOCs), the management of these resources makes it possible for states to use them as a foreign policy tool. With the higher prices of hydrocarbons in the international market since 2000, the reestablishment of NOCs became a new alternative for projecting power at a global level.

The aim of this work is to analyze the role of the main Russian NOC, Gazprom, for contemporary Russian foreign policy. In order to do so, Russian relations with four countries - Germany, Ukraine, China and Turkey - were investigated. The conclusion is that Gazprom's management by the Kremlin itself has generated positive results for the country, although such positive results do not cover all cases.

It has been found that, at different levels, Germany, China and Turkey have avoided opposing Moscow directly, with Germany being the most significant case. Germany's heavy dependence on Russian natural gas helps moderate any hostile stance against Moscow, regardless of which party is in power in Berlin. In the case of China, dependence on Russian hydrocarbons also plays an important role in the bilateral relationship, but other factors, in addition to energy issues, contribute to their approximation and convergence. In the case of Turkey, although dependence on Russian gas is also high, Turkey's strategic location has allowed Ankara to bargain with Moscow, softening, to some extent, Russia's power. Ukraine, on the other hand, is a clearly a dissonant case: even with a strong dependence on Russian gas, Kiev has taken stances that are clearly contrary to the interests of Moscow.
\end{abstract}

Key-words: NOCs, Gazprom, foreign policy, Russia, energy, natural gas. 


\section{INTRODUÇÃO}

Os combustíveis fósseis (petróleo, gás natural e carvão) são recursos fundamentais para a economia mundial e, por conseguinte, desempenham função importante nas relações internacionais. $\mathrm{O}$ acesso a fontes energéticas é essencial para o desenvolvimento de um país. O crescimento econômico e militar depende intensamente da força motriz gerada por esses recursos, consequentemente, a segurança energética é objetivo de todos os Estados. A história demonstra que países que detêm recursos muito demandados podem prosperar à custa dos demais. Em um mundo formado por países muito desiguais entre si, aqueles que dispõem de recursos imprescindíveis para o desenvolvimento conseguem afetar os acontecimentos fora das suas fronteiras (WALTZ, 1979).

Atualmente, mesmo com o desenvolvimento de fontes de energia alternativas, renováveis e menos poluentes, os combustíveis fósseis ainda representam $84 \%$ do consumo global e é certo que permanecerão como a mais importante fonte de energia por um período considerável. $\mathrm{O}$ aumento da população e a expansão da economia mundial implicam necessariamente maior demanda por energia. Embora os combustíveis renováveis devam aumentem sua participação na matriz energética global - além de se esperar um aumento na eficiência do uso de energia - os combustíveis fósseis continuarão mantendo um papel preponderante: o gás natural deve aumentar sua participação de $24 \%$ para $26 \%$ até 2035 , ao passo que o petróleo deve reduzir sua participação de $32 \%$ para $29 \%$ até o mesmo período (BP, 2016).

Nesse cenário, as empresas ligadas ao setor de hidrocarbonetos, e em especial as National Oil Companies (NOCs), deverão seguir desempenhando um papel fundamental nas relações internacionais contemporâneas. As NOCs controlam mais de $90 \%$ das reservas mundiais de petróleo e gás (LEIS; MCCREEY; GAY, 2012); consequentemente, elas vêm aumentando sua atuação no mercado mundial de energia, buscando se internacionalizar e competir em condições de igualdade com as grandes petroleiras transnacionais privadas, as chamadas International Oil Companies (IOCs).

Com o aumento dos preços das commodities globais (em especial do petróleo e do gás) no início de 2000, as NOCs ganharam novo vigor, sua expansão no mercado mundial de energia fez com que países ricos nesses recursos retomassem o debate sobre a importância dessas empresas para o desenvolvimento nacional, ao passo que os países 
consumidores redobraram as preocupações com sua segurança energética. Em alguns casos, as NOCs tornaram-se motores essenciais para a atuação internacional de nações detentoras de vastos recursos fósseis.

No que se refere à Rússia, particularmente, verifica-se que o Estado buscou retomar o controle sobre grandes empresas nacionais a partir de 2000, especialmente no setor de petróleo e gás. Política oposta ao que ocorrera na década de 1990, quando a maior parte do setor de energia da antiga União Soviética foi privatizado. Com base nesse contexto, este trabalho tem como objetivo analisar a importância da Gazprom para a política externa russa contemporânea, verificando se seu extenso controle sobre a produção e distribuição de gás confere a Moscou ganhos políticos no cenário internacional.

Nosso entendimento é o de que o aumento dos preços dos hidrocarbonetos no mercado mundial a partir da década de 2000 e a retomada de ativos de empresas de energia pelo Estado possibilitou ao governo russo impulsionar sua atuação no cenário internacional e desenvolver uma política externa mais assertiva, fazendo uso da chamada "arma energética"1. Desse modo, a Rússia estaria utilizando a Gazprom como instrumento para aproximar os países consumidores de gás dos seus interesses de política externa.

Nesse contexto, analisamos com mais profundidade como se dá o relacionamento com países de fundamental importância para os interesses russos: Alemanha, Ucrânia, China e Turquia. A análise dos casos demonstrou que, muito embora os quatro países sejam dependentes do gás russo em maior ou menor medida, tal dependência não tem sido suficiente para promover o alinhamento aos interesses de Moscou em todos os casos. Tal condição tem-se mostrado relativamente exitosa em relação à Alemanha, à China e à Turquia, mas não em relação à Ucrânia. Neste último caso, a posição geoestratégica deste país e as históricas desconfianças e resistências em relação à Rússia têm sido um entrave para a aproximação.

Kiev, assim como Ancara, consegue fazer uso de sua localização geográfica estratégica para pressionar Moscou, algo que China e Alemanha estão impossibilitadas de fazer. As particularidades do mercado do gás - fortemente dependente de gasodutos tornam os locais de chagadas de gás mais vulneráveis aos desígnios do fornecedor; ao

\footnotetext{
${ }^{1}$ O termo é uma analogia a expressão "oil weapon", criada durante a crise do petróleo de 1973 em referência ao embargo imposto pela Opep aos países que apoiaram Israel na Guerra de Outubro. Nesse contexto, o acesso a recursos naturais estratégicos passou a ser visto como uma nova arma de política externa.
} 
passo que os territórios que são rotas de passagem conseguem alcançar um certo poder de barganha. Desse modo, pode-se concluir que a Gazprom é um eficaz instrumento de política externa somente nos países em que o grau de dependência de gás é razoável e em que não haja entraves geopolíticos consideráveis.

A partir do estudo da Gazprom, buscamos também analisar qual o papel desempenhado pelas NOCs nas relações internacionais contemporâneas. A hipótese geral é a de que o controle sobre recursos como o petróleo e o gás permite aos países que detêm essas matérias-primas pôr em prática uma política externa mais influente e agressiva, que pode ser bastante vantajosa do ponto de vista do interesse nacional. É preciso observar, no entanto, em quais condições as NOCs operam com maior ou menor eficácia, uma vez que seu poder de influência não é ilimitado. Nesse sentido, acreditamos que a experiência russa pode servir como comparação para outros casos em que as NOCs são utilizadas como meio para se alcançar objetivos de política externa.

Com base nessa perspectiva, analisaremos, no primeiro capítulo, o mercado mundial de hidrocarbonetos e sua importância para as relações internacionais contemporâneas. No item 1.1, verificaremos o contexto histórico que ensejou o aparecimento e a expansão das NOCs. No item 1.2, analisaremos mais detidamente as particularidades do mercado de gás natural.

No segundo capítulo, examinaremos a importância do setor de hidrocarbonetos para a economia russa ao longo da história e a construção da Gazprom. No item 2.1, serão analisadas as consequências da descoberta do petróleo para a economia e para as relações internacionais da Rússia. No item 2.2, verificaremos a expansão do mercado de gás russo e sua interdependência com os mercados dos países vizinhos. No item 2.3, o período do governo de Boris Yeltsin, sob o qual grandes empresas do setor de energia foram privatizadas, será analisado. No item 2.4 , o período a ser examinado será a ascensão de Vladimir Putin ao poder, cuja administração empreendeu diversas medidas com a finalidade de retomar o controle de setores vistos como estratégicos, entre os quais se destaca a indústria de hidrocarbonetos, particularmente a Gazprom.

No terceiro capítulo, apresentaremos os estudos de caso: Alemanha, Ucrânia, China e Turquia e verificaremos o grau de sucesso das políticas energéticas russa em relação a esses países. A opção por esses quatros casos decorre da percepção de que a “arma energética" russa repercute de modo diferente nessas localidades. 
Na conclusão, avaliaremos se a hipótese apresentada corresponde à realidade observada nos estudos de casos selecionados. Além disso, examinaremos as perspectivas atuais para o mercado de energia e sua interligação com a política externa russa.

A fim de avaliar a hipótese proposta, este trabalho utilizará principalmente a metodologia qualitativa, com ênfase em estudo de caso. Reconhece-se nessa abordagem a oportunidade de expor e explorar o tema em análise com maior profundidade e abrangência. Algumas das vantagens do estudo qualitativo é a possibilidade de agregar fontes diversas, além de se estabelecer uma relação mais próxima com o objeto em estudo (FREITAS; JABBOUR, 2011). Destacamos, no entanto, que a opção pela investigação qualitativa não exclui o uso de dados quantitativos descritivos (números relacionados à produção, consumo, importação e exportação de gás) com o intuito de esclarecer e contextualizar aspectos da questão investigada.

Pretende-se, a partir de nossa pesquisa, enriquecer e avaliar o conhecimento sobre o assunto, possibilitando, assim, maior entendimento dos dados encontrados e, consequentemente, melhor compreensão da realidade estudada. 


\section{Mercado Mundial de Hidrocarbonetos}

\subsection{O Surgimento das NOCs e sua Importância nas Relações Internacionais.}

As NOCs podem ser definidas como empresas estatais - ou majoritariamente controladas pelo Estado - que operam no setor de petróleo e gás. Essas empresas são geralmente identificadas, em seus países de origem, como guardiãs dos recursos naturais da nação. Em seu dia a dia, elas precisam combinar a necessidade de atingir objetivos comerciais e econômicos com as expectativas domésticas sobre sua responsabilidade em relação ao desenvolvimento nacional (MARCEL, 2006).

No contexto doméstico, as NOCs geralmente desfrutam de posição única. São com frequência os principais empregadores e um investidor crucial no setor de pesquisa e desenvolvimento, sendo responsáveis por inúmeras iniciativas: desde inovações tecnológicas até obras de infraestrutura. As NOCs geralmente estão presentes em toda a cadeia de produção de petróleo e gás: do upstream (exploração e produção) ao downstream (refino e distribuição) (MARCEL, 2006).

Diferentemente do que ocorre no setor privado, em que o objetivo principal das IOCs é maximizar valor para os acionistas, obedecendo a certas restrições éticas e ambientais; no caso das NOCs, é preciso considerar outros critérios, uma vez que essas empresas foram criadas para fazer mais do que simplesmente gerar renda. Entre suas finalidades, segundo Stevens (2008), está a chamada "missão nacional", um conjunto de objetivos estratégicos que vão além de preocupações puramente comerciais e econômicas.

Essa "missão" geralmente é bastante complexa, uma vez que deriva da própria natureza dos governos, que, por sua vez, têm interesses distintos, além de não constituírem entidades monolíticas. Neles, vários atores com interesses diferentes interagem, o que repercute tanto nas expectativas em relação a essas empresas quanto nas suas ações.

No caso das NOCs, o pressuposto principal é o de que sua avaliação de desempenho não pode ser mensurada exclusivamente em função de sua performance econômica. Há de se considerar igualmente as diretrizes políticas que lhes são impostas pelo Estado que as controla. No que se refere à Gazprom, por exemplo, é preciso relacionar sua atuação com os objetivos geopolíticos do governo russo. 
Ao longo dos anos, o apoio à manutenção das NOCs tem oscilado. Em períodos de preços altos no mercado mundial, é comum que os Estados busquem a ampliação de seus quadros e de suas atividades-fim, surgem expectativas de que essas empresas, além de superar desafios comerciais, possam buscar outros objetivos do Estado. Períodos de preços baixos, porém, ensejam movimentos em direção à diminuição de seu tamanho, por meio de privatizações e da liberalização do setor de energia para a concorrência externa (MCPHERSON, 2013).

Para além da variação de preços, Stevens (2008) chama atenção para outro aspecto em relação ao surgimento e à expansão das NOCs. Segundo este autor, durante as décadas de 1950, 1960 e 1970, a aceitação da intervenção do Estado na economia era a ideologia predominante no contexto de falhas de mercado. Nesse sentido, políticas econômicas keynesianas, bem como o planejamento centralizado da União Soviética, legitimaram a criação de muitas NOCs. Porém, já nas décadas de 1980 e 1990, a ascensão do paradigma neoliberal na economia ensejou a desaprovação da intervenção estatal na alocação de recursos das NOCs, incentivando privatizações.

Em uma perspectiva histórica, verifica-se que, ainda em 1914, às vésperas da Primeira Guerra Mundial, o governo britânico adquiriu o controle majoritário da AngloPersian Oil Company ${ }^{2}$, criando, assim, uma das primeiras NOCs mundiais ${ }^{3}$. Dois anos antes, no contexto da disputa com a Alemanha pela maior e mais bem equipada Marinha mundial, Winston Churchill, então Primeiro Lorde do Almirantado Britânico, tomou a decisão de trocar o abastecimento dos navios de carvão (que o Reino Unido produzia em abundância) para o petróleo, uma disposição que mudaria para sempre o mercado mundial de energia (FROMKIN, 1989; VICTOR, 2013).

O primeiro resultado dessa decisão foi tornar o petróleo uma commodity mundial, transacionada internacionalmente, uma vez que o Reino Unido não possuía fontes suficientes desse recurso; o segundo foi tornar a questão do petróleo um assunto também político, porquanto passou a envolver também Estados nacionais, em decorrência da

\footnotetext{
${ }^{2}$ A Anglo-Persian (mais tarde Anglo-Iranian, British Petroleum e atualmente BP) foi criada em 1908 pelo financista inglês William D’Arcy. Em junho de 1914, o parlamento britânico aprovou a aquisição pelo governo de uma participação majoritária na empresa, a qual havia descoberto petróleo no sudoeste da Pérsia (atual Irã). Autores como Stevens (2003), no entanto, alegam que a BP nunca foi uma NOC pois havia um acordo específico entre o governo britânico e a BP pelo qual o governo obteve apenas o direito de nomear dois diretores, os quais foram autorizados a atuar como "independentes". Segundo este autor, ao longo de sua trajetória, a BP sempre atuou como uma IOC.

${ }^{3}$ O Império Austro-Húngaro foi o criador da primeira NOC, em 1908, então uma refinaria de petróleo sob o controle do Estado (VICTOR, 2013).
} 
importância fundamental desse recurso para a guerra. A substituição do carvão pelo petróleo tornou a frota britânica um adversário mais ágil e eficiente contra a marinha alemã, que crescia rapidamente. Durante a Primeira Guerra, a maioria das forças armadas dos países envolvidos também converteram suas frotas para o abastecimento de petróleo (CLAES, 2013; GHALEB, 2011; KONOPLYANIK, 2004).

Após o fim da guerra, a demandava por petróleo aumentava cada vez mais, tanto para fins militares quanto econômicos. Os países vencedores insistiram, portanto, na criação de esferas de influência sobre as antigas colônias, de modo a garantir o acesso privilegiado a seus recursos naturais. Os americanos, por sua vez, advogavam uma política de "portas abertas", a qual, em teoria, defendia o direito de empresas de todos os países firmarem acordos com as antigas colônias europeias. Essa política, na verdade, visava garantir que as empresas americanas também tivessem acesso ao petróleo do Oriente Médio e da Ásia Central (MOLCHANOV, 2013).

Embora o território dos Estados Unidos fosse rico em hidrocarbonetos, a quebra do monopólio da Standard Oil, em 1911, tornou mais difícil o acesso a jazidas para algumas das novas empresas que surgiram do desmembramento do poderoso império comercial criado por John D. Rockefeller ${ }^{4}$. Estas tiveram que expandir suas operações para além do território norte-americano, instalando-se, primeiramente, no México e na Venezuela e, depois, disputando com empresas europeias o acesso ao petróleo do Oriente Médio (ENERGY CHARTER, 2007; FUSER, 2005).

A resistência dos europeus, em especial dos britânicos, à entrada das empresas estadunidenses no Oriente Médio se tornou insustentável em razão das dívidas que esse país contraíra junto aos EUA durante a Primeira Guerra. Além do mais, as empresas britânicas precisavam de capital para desenvolver novas áreas de exploração. Assim, em julho de 1928, houve uma distribuição das ações da Iraqi Petroleum Company (IPC). A empresa foi dividia em quatro: a Exxon e Mobil (criadas após o desmembramento da Standard Oil) ficaram com 23,75\% de suas ações. Outras três parcelas de 23,75\% foram repartidas entre a Anglo-Persian, a Royal Dutch Shell e a Compagnie Française des

\footnotetext{
${ }^{4}$ Em 1904, A Standard Oil Trust, que reunia 40 empresas, controlava mais de $85 \%$ da produção de petróleo nos Estados Unidos (STEVENS, 2010). Em 1892, a Suprema Corte de Ohio declarou ilegal o monopólio e determinou sua cisão. No entanto, a principal empresa sucessora, a Standard Oil de Nova Jersey, permaneceu sob o controle dos Rockefellers até 1911, quando a Corte Suprema dos Estados Unidos determinou um novo desmembramento.
} 
Pétroles (CFP), restando 5\% ao fundador da empresa, Calouste Gulbenkian ${ }^{5}$, que recebeu a alcunha de "Senhor 5\%" (KEOHANE, 1984; FUSER, 2005).

Tal negociação ficou conhecida como "Acordo da Linha Vermelha", em referência à cor da linha traçada por Gulbenkian sobre o mapa do Oriente Médio. Nas áreas dentro desta linha, as empresas buscariam concessões conjuntas, por meio de joint ventures. Ao aderir ao acordo, as empresas americanas concordaram em não empreender explorações independentes ou fechar negócios dentro da linha vermelha sem a aprovação expressa e cooperação dos outros membros. Desse modo, as petroleiras americanas foram incluídas na repartição dos recursos fósseis do Oriente Médio, a política de "portas abertas" foi abandonada e a porta foi fechada para qualquer nova empresa (ANDERSON, 1981 apud CLAES, 2013).

Claes (2013) observa que, embora as grandes petroleiras privadas fossem importantes e que, em certa medida, empurrassem a administração de seus países para o Oriente Médio, os governos de Estados Unidos, Reino Unido e França tomaram para si o papel principal na definição das regras do jogo energético. Os acordos realizados foram resultantes de negociação interestatais. No entanto, logo as empresas obteriam o controle total sobre o negócio internacional de petróleo por meio de uma cooperação tácita.

Em agosto de 1928, três delas - Anglo-Persian, Shell e a Exxon - reuniram-se secretamente no castelo de Achnacarry, na Escócia, com o objetivo de estabelecer políticas de mercado comuns, a fim de evitar a concorrência predatória e controlar o mercado mundial de petróleo, o que fícou conhecido como o "Acordo de Achnacarry" ou "As Is" ("Como Está"). As demais petroleiras internacionais logo subscreveram o acordo. Essas empresas seriam mais tarde denominadas de as "Sete Irmãs" 6 ou "majors", uma referência ao controle que detinham do mercado mundial de petróleo, abrangendo toda a cadeia de produção: da exploração até a venda.

De acordo com Acordo de Achnacarry, as empresas participantes manteriam a parcela de mercado que já detinham, sem adentrar no mercado das demais - o mercado estadunidense ficou de fora desse compromisso em razão da legislação antitruste já em

\footnotetext{
${ }^{5}$ A IPC foi criada por Calouste Gulbenkian em 1925 como o nome de Turkish Petroleum. A empresa foi renomeada em 1931, após Gulbenkian obter os direitos exclusivos para exploração petróleo no Iraque. ${ }^{6}$ A expressão foi criada por Enrico Mattei, primeiro presidente da estatal italiana ENI. As "Sete Irmãs" eram: Exxon, Mobil, Shell, BP, Texaco, e duas empresas que mais tarde se fundiriam a criariam a Chevron: a Gulf Oil e a Standard Oil of California (SOCAL). Às vezes, uma oitava "irmã” era adicionada ao grupo: a Compagnie Française des Pétroles - CFP (mais tarde, Total) (MARCEL, 2006).
} 
vigor $^{7}$. Desse modo, o aumento no volume de vendas de cada empresa só seria possível em decorrência de um aumento na demanda mundial. $\mathrm{O}$ acordo também envolvia uma redução geral de custos, com o eventual aproveitamento de infraestrutura de produção e logística por empresas diferentes. Além disso, estabeleceu-se uma política de formação de preço para o petróleo, que deveria ter como base o custo de produção no Golfo do México, nos Estados Unidos, mais o valor do frete ("Gulf plus freight”), mesmo que o petróleo fosse extraído em outros lugares e tivesse composições diversas. Consequentemente, o mercado internacional passou a absorver quantidades crescentes de petróleo produzido a baixo custo no Oriente Médio sem que os preços diminuíssem (YERGIN, 1991; ENERGY CHARTER, 2007; STEVENS, 2016).

Paralelamente, outros Estados procuraram criar suas próprias empresas no setor de hidrocarbonetos buscando proteger o interesse nacional e reconhecendo a essencialidade desses recursos para um eventual conflito bélico: em 1922, criou-se na Argentina a Yacimientos Petrolíferos Fiscales (YPF); em 1924, a Compagnie Française des Pétroles (CFP) foi fundada na França; em 1926, a italiana Azienda Generale Italiana Petroli (AGIP) foi criada na Itália (VICTOR et al., 2012). Em 1937, o governo boliviano criou a estatal Yacimientos Petrolíferos Fiscales de Bolívia (YPFB) e, posteriormente, nacionalizou as reservas da Standard Oil no país. Em 1938, no México, o presidente Lázaro Cárdenas expropriou ativos de companhias estrangeiras e criou a Petróleos Mexicano (Pemex) ${ }^{8}$. (YERGIN, 1991; KRASNER, 1978; LUONG; SIERRA, 2015).

A Segunda Guerra Mundial tornou a importância estratégica do petróleo ainda mais evidente. Kelanic (2013) chama atenção para o fato de que, mesmo antes do início do conflito, a deficiência de suprimentos domésticos de petróleo moldou profundamente o comportamento dos países que entrariam na guerra. A Alemanha, por exemplo, antecipando a escassez de combustíveis durante o conflito, investiu pesadamente em fontes alternativos e buscou alianças econômicas com os dois maiores produtores de petróleo da Europa: Romênia e Rússia.

\footnotetext{
${ }^{7}$ Em 1890, o "Sherman Act" ou a "Lei Antitruste Sherman" tornou ilegal o estabelecimento de monopólios econômicos nos Estados Unidos. Em 1918, no entanto, houve a promulgação do "Webb-Pomerene Act", o qual permitiu às empresas americanas atuarem no mercado internacional sem observar as normas antitrustes domésticas. Internamente, a legislação do país continuou a proteger as empresas médias e pequenas que operavam no setor de petróleo. Desse modo, o "Acordo de Achnacarry" protegeu principalmente os interesses dos norte-americanos: tanto no mercado internacional quanto no doméstico (ENERGY CHARTER, 2007).

${ }^{8} \mathrm{O}$ contexto internacional, caracterizado pelo início das hostilidades entre Aliados e as potências do Eixo, favoreceu o governo de Cárdenas nas negociações com os Estados Unidos sobre as compensações que deveriam ser pagas as empresas americanas que até então operavam no país (YERGIN, 1991).
} 
Keohane (1984) observa que, no pós-guerra, os Estados Unidos passaram a apoiar regimes internacionais formais para áreas como comércio e economia. Para a área de energia, entretanto, Washington preferiu a consolidação de um regime mais restritios e liderados por empresas privadas. Segundo este autor, no curto e médio prazo, esta estratégia funcionou: a cooperação que se promoveu ajudou na recuperação econômica e política da Europa Ocidental e do Japão, bem como direcionou grandes investimentos para regiões produtoras na África e na Ásia, consolidando novas áreas de produção que alimentariam o significativo crescimento econômico que ocorreu nos anos seguintes ao fim da Segunda Guerra. No longo prazo, porém, tal sucesso foi limitado, porquanto não se institucionalizou um regime internacional que acomodasse o pleito crescente dos países produtores por maior controle sobre seus recursos naturais, o que gerou ameaças crescentes aos suprimentos de petróleo na Europa Ocidental, no Japão e mesmo nos Estados Unidos.

No decorrer da segunda metade do século XX, os países produtores de petróleo foram demandando maiores participações nos lucros das grandes empresas petroleiras internacionais que atuavam em seus territórios. Em 1943, o governo venezuelano decidiu instituir um imposto sobre os lucros das IOCs, em adição ao montante fixo dos royalties. A intenção era que o Estado venezuelano recebesse pagamentos iguais ao lucro líquido dessas empresas, princípio que ficou conhecido como "50/50" repercutiu externamente. Nos anos seguintes, os governos de Arábia Saudita (1950), Kuwait (1952) e Iraque (1952) pressionaram e conseguiram a adoção do mesmo sistema (YERGIN, 1991; STEVENS, 2010).

No Irã, o valor pago pela Anglo-Iranian - empresa que era majoritariamente controlada pelo governo britânico - correspondia a cerca de $9 \%$ das receitas do consórcio. No entanto, Londres - apesar das pressões de Washington, que temia o crescimento do nacionalismo iraniano e não concordava com o monopólio da Anglo-Iranian no país recusou, inicialmente, a fórmula "50/50" e se mostrou inflexível nas negociações com Teerã, aumentando o descontentamento da população e ampliando a popularidade do principal líder oposicionista, Mohammad Mossadegh. Em abril de 1951, Mossadegh tornou-se o primeiro líder democraticamente eleito na história do Irã, criando, em seguida, a National Iranian Oil Company (NIOC), a primeira NOC controlada por um país do

\footnotetext{
${ }^{9}$ As petroleiras estatais passaram a ter de pagar royalties de $16,66 \%$ (a taxa anterior era de $10 \%$ ) e uma soma fixa de imposto de renda de modo a garantir que $50 \%$ do lucro líquido da operação ficasse com o Estado venezuelano (FERNANDES; SILVEIRA, 1999).
} 
Oriente Médio (PIMENTEL, 2011; FUSER, 2005). Como resultado, as majors e o governo britânico, por conseguinte, impuseram um embargo econômico ao petróleo iraniano. Para manter o mercado estável, aumentou-se a produção no Iraque, Kuwait e Arábia Saudita. As exportações iranianas caíram dramaticamente, o país passou a enfrentar severas dificuldades econômicas (FUSER, 2005; KRASNER, 1978).

Em agosto de 1953, diante da crescente preocupação em Washington de que Mossadegh pudesse se aliar à URSS, a CIA, juntamente com o serviço secreto inglês, planejou sua remoção e o restabelecimento no poder do xá Reza Pahlevi, que passou a governar com o apoio norte-americano e abriu o país para um consórcio internacional de exploração do petróleo. As negociações foram encabeçadas pelo Departamento de Estado do governo norte-americano: a Anglo-Iranian teve sua participação reduzida para $40 \%$. O restante foi dividido entre empresas americanas $(40 \%)^{10}$, a holandesa Shell $(14 \%)$ e a francesa CFP (6\%). A fórmula "50/50" foi finalmente estabelecida (KEOHANE, 1984; YERGIN, 1991).

Não obstante, uma característica crucial do novo acordo foi o fato de a NIOC permanecer como proprietária dos recursos petrolíferos em nome do Estado iraniano. As empresas estrangeiras eram "contratadas" pela a NIOC. Desse modo, verifica-se que, apesar do revés das políticas nacionalistas do Irã, as novas condições contratuais tornamse mais favoráveis ao país produtor. As reservas de petróleo iranianas, que antes eram consideradas propriedade das empresas estrangerias, passaram a ser reconhecidas como pertencentes ao Estado, algo que se repetiria em outros países nos anos seguintes, sendo, atualmente, o modelo dominante no mundo, com notável exceção dos países de tradição anglo-saxã (PIMENTEL, 2011; MARCEL, 2006; YERGIN, 1991).

Com a consolidação da fórmula "50/50", as IOCs criaram uma política de preços que ficou conhecida como "posted prices" ("preços publicados" ou "preços de referência”). De acordo com esse método, o cálculo dos royalties que deveriam ser pagos aos países produtores não tinha como base os preços reais, uma vez que não eram descontados sobre os preços praticados no mercado internacional, mas sobre o preço de transferência que as empresas utilizavam em suas transações entre matriz e filial. Desse modo, as majors pagavam apenas uma porcentagem do preço estabelecido por elas mesmas, os quais supostamente refletiam os preços de mercado. A natureza unilateral dessa política foi fonte de frequentes desentendimentos entre as IOCs e os países

${ }^{10}$ Cinco majors americanas obtiveram $8 \%$ cada: Esso, Texaco, Gulf Oil, Socony Mobil e Standard Oil (California). 
produtores até a eclosão do Primeiro Choque do Petróleo, em 1973, quando esses últimos conseguiram tomar para si a precificação de seus produtos (ENERGY CHARTER, 2007; FATTOUH, 2007; STEVENS, 2010).

No final da década de 1950, o aparecimento de novos campos de produção de petróleo na África (Argélia, Líbia e Nigéria) e o aumento da produção na União Soviética ampliaram a disponibilidade de petróleo no mercado mundial, diminuindo os preços. Além disso, em 1959, os Estados Unidos instituíram um sistema de cotas de importação de petróleo ${ }^{11}$, que permaneceria em vigor até 1971. Essa medida procurava proteger os produtores nacionais do petróleo mais barato oriundo do Oriente Médio. Desse modo, Washington instituiu uma política de petróleo concebida principalmente para proteger os produtores americanos da concorrência dos volumes excedentes no mercado internacional. Ao longo da década de 1960, esses controles de importação mantiveram os preços do petróleo doméstico em cerca de $30 \%$ acima do preço do mercado mundial (IKENBERRY, 1988). Em contrapartida, tal regra ajudou a manter os preços internacionais baixos, em razão do excesso de oferta fora dos EUA.

O aumento da oferta e a consequente diminuição dos preços internacionais de petróleo intensificou movimentos nacionalistas já em expansão nos principais países produtores. Em uma tentativa de se organizar para coordenar posições contra as mudanças de preços impostas pelas IOCs por meio dos "posted prices" (os preços pagos aos países produtores haviam sido reduzidos duas vezes em menos de um mês), os cinco maiores produtores mundiais (Iraque, Irã, Arábia Saudita, Kuwait e Venezuela) reuniram-se em Bagdá, em setembro de 1960, e criaram a Organização dos Países Exportadores de Petróleo (Opep). ${ }^{12}$

A criação da Opep, contudo, não teve efeito imediato. As decisões sobre volume de produção, vendas e preços seguiram sob o controle das IOCs. Segundo Keohane (1984), isso ocorrera porque as relações de poder nesse regime eram altamente assimétricas. As grandes empresas possuíam melhores informações sobre os mercados e a tecnologia para extração do petróleo. Ademais, detinham recursos financeiros e capacidades de produção, transporte e comercialização com os quais os países produtores

\footnotetext{
${ }^{11}$ Alguns anos após a Segunda Guerra, os americanos deixaram de ser autossuficientes em petróleo, o que alimentava temores quanto à segurança energética do país. Em 1957, a administração do presidente Dwight Eisenhower, pressionado pelo lobby dos produtores locais, estabeleceu um programa voluntário que tinha como objetivo manter a importação de petróleo abaixo de $12 \%$; no entanto, ao verificar que o programa não surtira efeito, as cotas se tornaram obrigatórias a partir de 1959 (FUSER, 2007; STEVENS, 2010).

${ }^{12}$ Além dos membros fundadores, fazem atualmente parte da Opep: Catar, Indonésia, Líbia, Emirados Árabes Unidos, Argélia, Nigéria, Equador e Angola.
} 
não podiam competir. Acima de tudo, as majors, quando ameaçadas por qualquer movimento político revolucionário ou nacionalista, podiam sempre contar com o apoio de seus países sede.

Marcel (2006) chama atenção para o fato de essas empresas operarem separadamente do resto da economia dos países produtores, o que tornava quase impossível aos governos locais ter acesso a informações relativas à própria indústria de petróleo. A falta de controle sobre os mercados impedia que os países produtores solucionassem a principal questão que prejudicava o poder de barganha da Opep: durante quase toda a década de 1960 houve excesso de oferta de petróleo no mercado mundial.

Em 1967, após a eclosão da Guerra dos Seis Dias entre israelenses e árabes (Egito, Síria e Jordânia) e a vitória de Israel, a Arábia Saudita decidiu impor um embargo às exportações de petróleo aos Estados Unidos, Reino Unido e Alemanha Ocidental, tendo sido acompanhada pelos demais países árabes membros da Opep. Tal embargo, no entanto, não produziu o efeito desejado. Diferentemente do que ocorreria em 1973, havia excesso de oferta de petróleo no mercado internacional. Em resposta, o governo dos Estados Unidos levantou restrições antitrustes para permitir o intercâmbio e a cooperação entre as IOCs, a fim de suprir a queda das importações dos países árabes. Irã e Venezuela também aumentaram a produção. Assim, embora as exportações de petróleo por parte dos países árabes tenham caído em cerca de 60\%, o embargo teve de ser encerrado cerca de três meses depois (YERGIN, 2012; FUSER, 2005).

Verificando que o efetivo controle sobre seus recursos naturais era bastante limitado, a Opep publicou em 1968 as chamadas "Diretrizes de Política de Petróleo", um documento no qual a organização declarava que os Estados produtores deveriam ter maior participação nas empresas petrolíferas, além da oportunidade de realizar estudos geológicos, extração de petróleo e o direito de controlar os preços de referência. As concessões para novas explorações foram suspensas (MARCEL, 2006).

Concomitantemente aos avanços dos países da Opep em direção a um maior controle sobre seus recursos, o cartel das "Sete Irmãs" foi afetado pelo surgimento e expansão de outras petroleiras menores: as chamadas "independentes" (Phillips, Amoco, Occidental, etc.) e as NOCs europeias (ENI, Repsol, etc.). Em setembro de 1969, um golpe de Estado levou ao poder da Líbia Muhamar Kadafi, que passou a pressionar as diversas empresas que atuavam no país para que subissem os preços pagos pelo petróleo líbio e aumentassem para 58\% a participação do país em seus lucros. 
Inicialmente, as majors se recusaram a atender as demandas de Kadafi, mas para empresas menores, como a californiana Occidental, que não possuía operações em outros países, não restavam alternativas. Em setembro de 1970, a Occidental concordou como os novos termos do governo líbio. Logo em seguida, as demais empresas também cederam, surgindo um novo precedente para o relacionamento entre IOCs e Estados nacionais (FUSER, 2005; STEVENS, 2010).

Os demais países produtores seguiram o mesmo caminho e também obtiveram aumento em suas participações no lucro. Em dezembro de 1970, a Venezuela exigiu que sua participação subisse para $60 \%$, assumindo o direito de fixar unilateralmente os preços de referência. Em setembro de 1973, Kadafi anunciou a expropriação de 51\% dos ativos das empresas petrolíferas que atuavam em território líbio, dando início a série de nacionalizações no setor de hidrocarbonetos que ocorreriam até o fim da década, responsável pelo surgimento de grande parte das NOCs atuais (KRASNER, 1978; COOPER, 2011).

No entanto, foi com a Guerra de Outubro (ou Guerra do Yom Kippur ou, ainda, Guerra do Ramadã) ${ }^{13}$, entre árabes e israelenses, em 1973, que a questão do petróleo ganhou maior notoriedade mundial. O uso do petróleo como arma política - "oil weapon" - surge como uma novidade nas relações internacionais do período ${ }^{14}$. Ao cortar o volume de produção e impor um embargo no fornecimento de petróleo, o objetivo declarado dos países árabes membros da Opep era punir as potências ocidentais pela ajuda militar oferecida a Israel durante o conflito. Segundo Gaidar (2007), porém, a guerra foi mais uma desculpa do que o principal motivo pelo corte de produção e embargo. As condições para a ascensão da Opep como ator principal no mercado mundial de petróleo já estavam consolidadas. As forças de mercado começavam a jogar favoravelmente aos países produtores: o consumo de petróleo nos EUA aumentara significativamente nos últimos anos (em 1967, as importações eram responsáveis por 19\% do consumo norte-americano,

\footnotetext{
13 A Guerra tem início em 6 de outubro de 1973 com tropas egípcias e sírias ultrapassando as linhas de cessar-fogo de 1968, recuperando parte dos territórios perdidos na Guerra dos Seis Dias. Os EUA, em seguida, supriram os israelenses com materiais bélicos, permitindo a Israel vencer a guerra em três semanas. Em 25 de outubro tem início um cessar-fogo mediado pela ONU.

${ }^{14}$ Ghaleb (2011) cita precedentes como os casos da Itália, em 1935, quando a Liga das Nações impôs um embargo no fornecimento de petróleo àquele país em razão da invasão da Etiópia (o qual não foi respeitado), e do embargo que os EUA impôs ao Japão em 1941, durante a Segunda Guerra Mundial. No entanto, o embargo de 1973 é de fundamental importância porque sinaliza um momento em que, pela primeira vez na história, potências mundiais se viram totalmente dependentes, para o seu suprimento de recursos essenciais, de países muito mais fracos.
} 
seis anos depois, essa porcentagem já atingira 35\%) ${ }^{15}$. Em abril de 1973, o governo de Richard Nixon já havia sido obrigado a extinguir o sistema de cotas de importação de petróleo criado em 1959 pela administração Eisenhower (COOPER, 2011).

Keohane (1984) destaca que, em 1967, os Estados Unidos eram "parte da solução" para a primeira tentativa de embargo feita pelos países árabes da Opep. A baixa dependência de importações permitiu ao governo americano ajudar no socorro de europeus e japoneses. Em 1973, no entanto, os EUA já eram "parte do problema". Sua base de recursos petrolíferos estava bastante enfraquecida e os americanos não conseguiriam compensar seus aliados pelo embargo no Oriente Médio. O aumento vertiginoso do consumo de petróleo nos Estados Unidos fortaleceu a posição dos países produtores.

Com o início do conflito, os países árabes e as IOCs reuniram-se em Viena, em 8 de outubro, para negociar um novo aumento de preços. As negociações, porém, fracassarem. Em decorrência, em 16 de outubro, os países árabes membros da Opep mais o Irã reuniram-se no Kuwait e decidiram aumentar unilateralmente os preços, de US\$3,01 para US\$ 5,11 o barril. Além disso, todos os países árabes presentes no encontro decidiram impor um corte de produção de 5\% ao mês até a retirada de Israel dos territórios ocupados na Guerra dos Seis Dias. No dia seguinte, a Arábia Saudita respondeu ao transporte aéreo de armas e suprimentos americanos para Israel cortando sua produção de petróleo em $10 \%$, enquanto Abu Dhabi anunciou um embago ${ }^{16}$ ao fornecimento. No dia 18 de outubro, Kadafi também anunciou um embargo e aumentou o preço do petróleo líbio de US\$ 4,90 para US\$ 8,92. Por fim, em 20 de outubro, a Arábia Saudita ${ }^{17}$ aderiu ao embargo, sendo seguida, no dia seguinte, por Kuwait, Catar, Barein e Dubai ${ }^{18}$ (FATTOUH, 2007; FUSER, 2005; COOPER, 2011).

Ressalte-se que os membros não árabes da Opep não participaram do embargo. $\mathrm{O}$ Irã até mesmo aumentou sua produção para mitigar o impacto da saída do petróleo árabe do mercado e também lucrar mais. Nesse contexto em que importantes produtores operavam abaixo de sua capacidade, o xá Reza Pahlevi convocou a Conferência de Teerã, realizada em 22 de dezembro de 1973. O xá liderou as negociações para um novo reajuste

\footnotetext{
${ }^{15}$ Embora os EUA se mantivessem como o maior produtor mundial de petróleo até 1970, ano em que sua produção atingiu o pico de 11,3 milhões de barris por dia (COOPER, 2011).

${ }^{16} \mathrm{O}$ embargo não atingiu apenas os EUA, mas todos aqueles países que os árabes consideravam ter apoiado Israel de algum modo: Holanda, Rodésia, África do Sul e Portugal.

${ }^{17}$ Cinco semanas após ter imposto o embargo, Riad voltou a fornecer petróleo aos EUA secretamente (COOPER, 2011; KELANIC, 2016).

${ }^{18}$ A Argélia já havia aderido ao embargo.
} 
nos preços e o fim da política de "posted prices". Ao final, os preços da Opep foram novamente elevados, de US\$ 5,11 para US\$11,65 (FATTOUH, 2007).

\section{Figura 1 - Gráfico da Média Anual dos Preços do Petróleo de 1973 a $1989^{19}$}

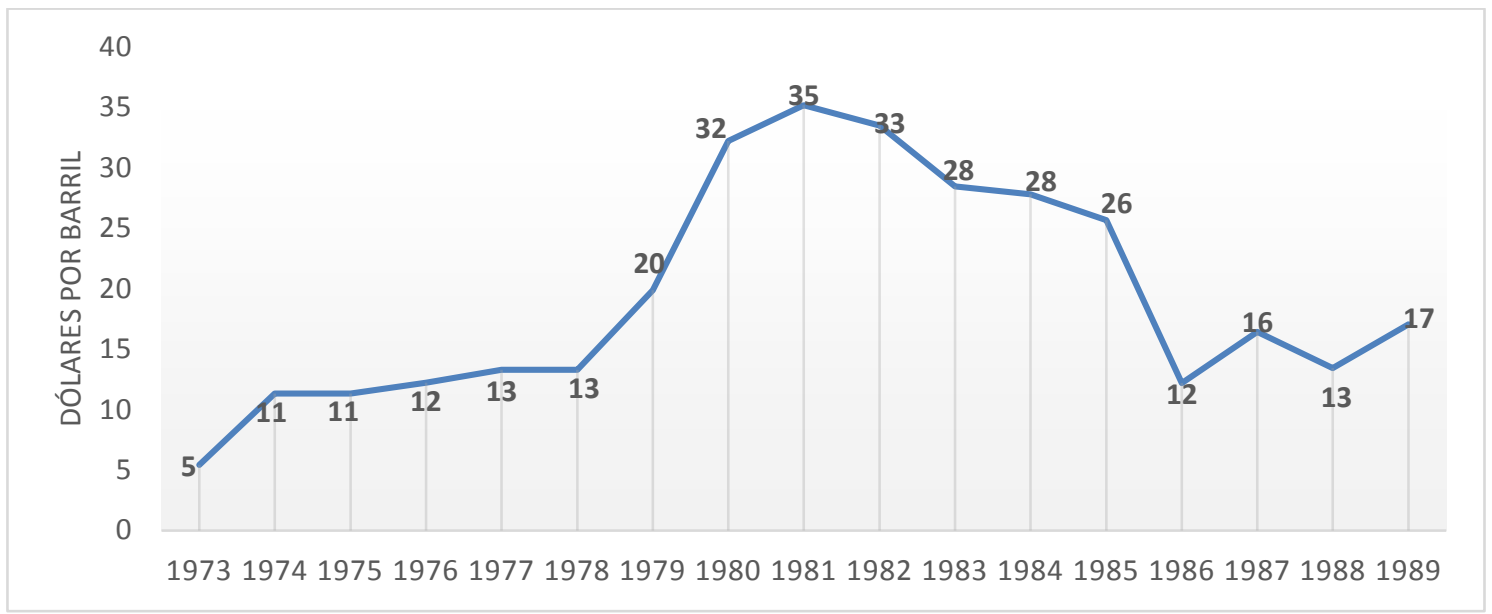

Elaboração Própria/Fonte: EIA

Essa reação em cadeia nos preços do petróleo é o que ficou conhecido na história como o "Primeiro Choque do Petróleo", fato que desencadeou uma severa crise econômica global e proporcionou aos principais países produtores uma proeminência até então inédita no cenário internacional, demonstrando que os detentores dessa matériaprima essencial poderiam reequilibrar a balança de poder mundial em seu favor.

Nesse novo cenário, a primeira reação dos países industrializados foi dissonante. Grande parte dos países da Europa Ocidental procurou se distanciar daqueles que foram alvos do embargo, a fim de conquistar a boa vontade dos árabes. França e Grã-Bretanha tentaram garantir suprimentos preferenciais, exercendo pressão sobre as petroleiras de seus países. O Japão, por sua vez, fez declarações pró-árabes, o que possibilitou a este país ser incluído em uma lista de prioridades (KEOHANE, 1984).

Nos Estados Unidos, ainda em novembro de 1973, o presidente Nixon lançaria o "Projeto Independência" ("Project Independence"), tendo como objetivo a independência energética dos EUA de qualquer fonte externa até o final da década de 1970. Tal iniciativa compreendia o aumento das pesquisas sobre fontes alternativas de energia, maior

\footnotetext{
${ }^{19}$ Os valores representam a média de preços do petróleo bruto importado pelos EUA durante o período na modalidade FOB (Free on Board). Os valores são nominais, portanto medem o valor em dólares na época da comercialização.
} 
exploração das reservas domésticas e economia de combustíveis. No entanto, o projeto foi sendo gradualmente abortado na administração seguinte de Gerald Ford (1974-1977).

Assim, apesar das medidas iniciadas pelo Projeto Independência, em meados da década de 1970, a economia norte-americana encontrava-se ainda mais exposta aos preços do petróleo ditados pela Opep, $40 \%$ do consumo doméstico dependia de matériaprima importada (FUSER, 2005; COOPER, 2011; JAFFE; SOLIGO, 2008).

Nesse contexto em que o ambiente econômico era bastante favorável aos produtores, os países em desenvolvimento (tanto os membros da Opep quanto outros países) passaram a demandar maior participação nas concessões já existentes ou optaram pela completa nacionalização das indústrias petrolíferas localizadas em seus territórios. Foi nesse contexto que surgiu grande parte das NOCs atuais, a exemplo da malasiana Petronas (1974), da venezuelana PDVSA (1975), da KPC no Kuwait (1975), da angolana Sonangol (1976), e da nigeriana NNPC (1977). A Aramco foi nacionalizada em três estágios, entre 1973 e 1980 . Todos esses processos foram decorrentes da nacionalização de ativos de empresas internacionais que atuavam nesses países (VICTOR et al., 2012).

Observe-se que as nacionalizações não retiraram dos mercados a maioria das IOCs, o aumento dos preços internacionais decorrente do Primeiro Choque do Petróleo propiciou a elas, inclusive, um aumento temporário em suas receitas (KRASNER, 1978). Todavia, a disrupção da cadeia integrada sobre a qual detinham total controle ensejou o aparecimento de novos atores no mercado internacional, rompendo com seu domínio exclusivo do mercado mundial de energia (FATTOUH, 2007).

Stevens (2010) observa que as NOCs se tornaram, na década de 1970, um instrumento de política governamental, com o objetivo principal de assegurar os direitos soberanos sobre os recursos naturais do país. Antes de 1973, em especial no Oriente Médio, havia uma crescente insatisfação com as antigas concessões, que eram demasiadamente longas. No Irã, Iraque, Kuwait e Arábia Saudita, o tempo médio dessas licensas era de 82 anos. Além disso, as IOCs empregavam poucos trabalhadores locais e mantinham controle quase exclusivo das posições de alta gerência. Essas empresas eram vistas, portanto, como uma extensão dos poderes coloniais de seus países-sede. O controle estatal sobre as atividades da indústria do petróleo através das NOCs tornou-se um símbolo de orgulho nacional, contagiando diferentes países.

Outro argumento em favor das nacionalizações eram as preocupações sobre o esgotamento desses recursos e a ideia de que, deixadas a si mesmas, as companhias petrolíferas privadas tinham um horizonte temporal demasiado curto, explorando as 
reservas de modo insustentável, visando apenas o lucro imediato. O controle desses recursos pelo Estado garantiria uma produção adequada tendo em vista sustentabilidade da produção a longo prazo (STEVENS, 2003).

No que se refere à relação entre as IOCs e os Estados, é importante destacar, ainda, o conceito da "barganha obsolescente" (obsolescing bargain) de Vernon (1971), o qual verifica que, inicialmente, as petroleiras têm maior poder de barganha junto aos Estados em que operam, quando ainda podem escolher para onde ir, levando seu capital. Todavia, após se estabelecerem e realizarem uma quantidade substancial de investimentos, elas se tornam reféns dos Estados, por já terem efetuado custos irrecuperáveis, enquanto os Estados podem sempre impor condições adicionais às empresas, tais como aumento de impostos, restrições trabalhistas, ambientais, etc. Nesse momento, segundo Vernon, as demandas para renegociação de contratos ou, até mesmo, de nacionalização das operações começam a emergir. Este processo geralmente é desencadeado por uma nova descoberta significativa, pela mudança de governo ou pelo aumento dos preços no mercado internacional. Assim, é provável que o aumento dos preços desencadeado pelo Primeiro Choque do Petróleo tenha criado um contexto favorável para que os Estados produtores demandassem melhores termos ou assumissem para si as principais decisões de gestão da indústria de petróleo.

Em contrapartida aos movimentos de nacionalização nos países em desenvolvimento, os países desenvolvidos buscaram criar novas políticas que lhes garantissem o acesso a essas matérias-primas - protegendo-os das oscilações bruscas de preços - e ajudassem no desenvolvimento fontes de energia alternativas. No início de 1974, os Estados Unidos convocaram uma conferência que contaria com a participação dos principais países capitalistas consumidores de petróleo. Mais tarde, dezesseis deles criariam a Agência Internacional de Energia (International Energy Agency - IEA) com o objetivo de diminuir as dificuldades causadas pelas interrupções no fluxo de combustíveis e contrabalançar o poder de mercado da Opep (KEOHANE, 1984; FUSER, 2005).

A nova organização planejou sistemas de segurança para lidar com interrupções no fluxo de fontes de combustíveis e evitar possíveis competições predatórias entre empresas de países industrializados, o que poderia pôr em risco o suprimento de energia. Esse sistema, que foi sendo ampliado e atualizado com o decorrer dos anos, continua a 
ser a base para a segurança energética dos países-membros da AIE atualmente ${ }^{20}$ (CLAES, 2013; YERGIN, 2012).

A sensação de escassez no mercado de hidrocarbonetos deu início a uma busca frenética por novas fontes de suprimento em todas as regiões. Nos países desenvolvidos, políticas governamentais promoveram maior eficiência de combustível em automóveis e encorajou empresas de energia elétrica a diversificar suas fontes primárias. Além disso, províncias petrolíferas, que anteriormente eram vistas como economicamente inviáveis, voltaram a se tornar atrativas em razão do aumento dos preços do petróleo no mercado mundial. O Alasca e o Mar do Norte (Reino Unido e Noruega), por exemplo, surgiram como novas áreas produtoras dentro de grandes países consumidores. Também houve aumento de produção de petróleo em países que não faziam parte da Opep, como no México e na União Soviética (YERGIN, 2012).

Em 1978, os trabalhadores da indústria petrolífera iraniana entraram em greve, um fator significativo na subsequente derrubada do xá Reza Pahlevi e no início da Revolução Iraniana. Esses eventos, juntamente com a guerra Irã-Iraque, de 1979, ensejaram o Segundo Choque do Petróleo, tornando o patamar de preços desse recurso ainda mais elevado (ver figura 1). A subsequente invasão soviética ao Afeganistão adicionaria ainda mais instabilidade ao mercado mundial de energia.

A perspectiva de preços constantemente altos no futuro contribuiu ainda mais para o aumento da exploração de petróleo em regiões não tradicionais, bem como a ampliação de investimentos em projetos de geração de energia de fontes alternativas. Assim, a década de 1980 experimentaria uma reviravolta no mercado global de energia, iniciando um período marcado pelo aumento na oferta mundial e pela acentuada queda nos preços. Em 1982, a produção de petróleo em países não membros da Opep superou, pela primeira vez, a produção dos países membros. A parcela de mercado dominada pela Opep caiu de 52\% em 1973 para 30\% em 1985 (FATTOUH, 2007).

Tendo em vista esse cenário, a Opep buscou a retomar sua parcela de mercado impondo cotas de produção a partir de 1983, passando a atuar, de fato, como um cartel, com a Arábia Saudita operando como o regulador de última instância, ajustando sua

\footnotetext{
${ }^{20}$ A Agência Internacional de Energia é uma subsidiária da OCDE e possui 29 países-membros. Para tornarse membro da agência os países devem obrigatoriamente ser membros da OCDE, embora a presença nesta organização não garanta participação na AIE. Por exemplo, países como o Chile, Israel, México, Islândia e Eslovênia são membros da OCDE mas não fazem parte da AIE. A agência prescreve que seus membros devam deter reservas de petróleo equivalentes a 90 dias de importações. Seu Mecanismo de Resposta de Emergência (Emergency Response Mechanism - ERM) prevê uma liberação coordenada dos estoques em caso de interrupções de fornecimento no mercado mundial (IEA, 2016; MITCHELL et al., 2012).
} 
produção com o objetivo de garantir que a dos demais países-membros não ultrapassassem 14,5 milhões de barris por dia (KEOHANE, 1984). Tal política, no entanto, mostrou-se infrutífera. Apesar dos repetidos cortes de produção realizado pelos sauditas, os demais membros da Opep frequentemente desrespeitavam suas $\operatorname{cotas}^{21}$, o que lhes permitia enriquecer à custa dos cortes de produção da Saudi Aramco. Segundo Gholz e Press (2010), em agosto de 1981, os sauditas eram responsáveis por $49 \%$ da produção da Opep e, após cinco anos de cortes unilaterais, a produção saudita passou a representar apenas 16\%. Ainda assim, a Opep não conseguiu evitar que novos produtores expandissem seus mercados em detrimento dos países membros da organização (PIMENTEL, 2011; GAIDAR, 2007).

Nessa conjuntura e com o objetivo de readquirir sua parcela de mercado, o governo saudita decidiu, em 1985, interromper os cortes e aumentar a produção ${ }^{22}$ a fim de diminuir os preços e retirar do mercado os produtores que tinham custos de produção mais altos. Esse aumento expressivo causou um impacto radical no mercado mundial de petróleo e atingiu severamente a economia de países como o México, Canadá e da União Soviética $^{23}$ (PIMENTEL, 2011; GAIDAR, 2007).

A partir de 1987, a New York Mercantile Exchange (NYMEX) estabeleceu operações regulares para a comercialização em bolsa de contratos de petróleo - operações esporádicas, mas pouco relevantes, existiam desde o começo da década de 1980. Em 1988, a International Petroleum Exchange (IPE) de Londres seguiu o mesmo caminho, sinalizando para os mercados que o petróleo poderia se tornar apenas mais uma commodity, com preços competitivos, um mercado "spot" (à vista) e um mercado futuro (ENERGY CHARTER, 2007; STEVENS, 2010). A partir de então, os mercados spot e futuro passaram a servir de referência para o preço internacional do petróleo ${ }^{24}$.

\footnotetext{
${ }^{21}$ Vale destacar que nesse período, dois membros importantes da organização, Irã e Iraque, estavam em guerra.

${ }^{22}$ De dois milhões para cinco milhões de barris por dia.

${ }^{23}$ Gaidar (2007) e Schutte (2011) argumentam que a decisão sobre o aumento da produção pelos sauditas teria sido decorrente de um pedido do governo estadunidense. No contexto da Guerra Fria, a política externa do presidente Ronald Reagan buscava pressionar por mudanças políticas na União Soviética por meio da fragilização de sua economia. É possível, ainda, que outros fatores geopolíticos também tenham contribuído para a decisão de Riade de aumentar a produção: os sauditas encaravam a ação militar soviética no Afeganistão como uma ameaça, fato que os aproximou de Washington. De todo modo, é preciso destacar que o descumprimento das cotas por parte dos outros membros da Opep e o crescimento da produção em países não membros da organização representaram um enorme impacto negativo para as receitas da Arábia Saudita. Nesse cenário, razões domésticas de ordem econômica também se mostravam urgentes.

${ }^{24}$ A partir do Primeiro Choque do Petróleo, o preço de referência do petróleo no mercado internacional passou a ser o Arabian Light, proveniente da Arábia Saudita (FATTOUH, 2007). No início da década de 1980, Riad modificou o método de cálculo de sua exportação de petróleo. Introduziu-se a fórmula conhecida como "netback pricing", a qual vinculou o valor do petróleo bruto aos preços no mercado à vista (spot) dos
} 
Concomitantemente ao período de preços baixos no setor de hidrocarbonetos, que predominou durante a maior parte das décadas de 1980 e 1990 (com a exceção de curtos intervalos de tempo, como durante a Guerra do Golfo), houve um aumento nos processos de privatização do setor de energia em todo o mundo. O colapso do preço do petróleo marcou uma grande mudança no poder de barganha entres as partes. As receitas mais baixas levaram alguns governos a tentarem atrair novamente as majors para seus países, na esperança de que seu envolvimento compensasse a queda dos preços, por meio da produção de volumes maiores (STEVENS, 2010). Assim, muitas NOCs perderam força ao longo das décadas de 1980 e 1990, na medida em que se viram descapitalizadas para manterem atividades exploratórias ou para desenvolverem reservas já descobertas, permitindo um significativo reposicionamento das IOCs, que, por meio de fusões e jointventures, conseguiram retomar parcialmente seu poder sobre o mercado mundial.

A década de 2000, em contrapartida, dá inicio a um novo período de preços altos, ensejando o reaparecimento do chamado "nacionalismo energético" (ou "resource nationalism"), em referência à reafirmação da soberania do Estado sobre seus recursos naturais (STEVENS, 2010; PIMENTEL, 2011). Nesse contexto, as NOCs, que, ao longo da década de 1990, haviam sobrevivido às privatizações e às vendas de ativos, buscaram retomar o controle sobre seus recursos naturais. $\mathrm{O}$ aumento no preço das commodities na década de 2000, em especial no setor de energia, ensejou o restabelecimento dessas empresas, inclusive por meio de incentivos econômicos governamentais. Em muitos casos, houve a facilitação de fusões entre corporações domésticas e a proibição de que seus ativos estratégicos fossem adquiridos por empresas estrangeiras. Exemplos como o a nacionalização da indústria de petróleo e gás na Bolívia, em 2006; a conversão das multinacionais exploradoras de hidrocarbonetos na Venezuela em empresas mistas sob o controle da Petróleos de Venezuela S. A. (PDVSA), entre 2005 e 2007; ou mesmo as mudanças da lei do petróleo no Brasil em $2010^{25}$ foram verificadas em todos os continentes.

produtos refinados. O "netback pricing" foi seguido por um breve e malsucedido sistema preços fixos. No final de 1987, no entanto, esse sistema foi completamente abandonado. A partir de então, passaram a ser introduzidas fórmulas de preços especificas para cada região geográfica, sistema que permanece vigente até hoje. O mercado americano, por exemplo, utiliza como principal indicador de preço o WTI (West Texas Intermediate), já o mercado europeu e o petróleo oriundo do Oriente Médio têm utilizado o Brent como indicador. Ambos são considerados Light Sweet, o petróleo de melhor qualidade, mas o WTI tem qualidade ligeiramente superior ao Brent, portanto, é geralmente um pouco mais caro que este.

${ }^{25}$ Em 2010, após a descoberta do pré-sal, o governo brasileiro decidiu adotar o regime de partilha para os novos campos descobertos. Desde 1997 vigia o regime de concessão. Além disso, estabeleceu que a Petrobrás deveria ter uma participação mínima de $30 \%$ em qualquer consórcio formado para explorar as novas áreas. 
Nesse contexto, emergem novas críticas sobre o papel desempenhado por essas empresas. Autores como Jaffe e Soligo (2008), por exemplo, são críticos à atuação das NOCs por considerarem que elas distorcem o mercado global (e nacional) de energia em razão de seu acesso facilitado a crédito e a outras conveniências em seus países de origem. Além disso, o controle estatal, ao impor às NOCs metas que não são exclusivamente econômicas, as obrigaria a alocar recursos de modo ineficiente, gerando diminuição de receitas e prejudicando sua própria sustentabilidade econômica.

Mcpherson (2013), por sua vez, ressalta que as NOCs, por demandarem um grande volume de capital em suas operações - uma característica do setor de energia -, apropriam-se de receitas orçamentárias que são extremamente necessárias em outras áreas, fazendo com que setores como o de saúde, educação, infraestrutura sejam prejudicadas na alocação de recursos. Além disso, o fomento às NOCs aumentaria o risco de se estimular apenas um setor da economia, abrindo espaço para o aparecimento da chamada da "doença holandesa". ${ }^{26}$

Por outro lado, autores como Marcel (2006) argumentam que as NOCs, ainda que às vezes administradas de modo menos eficiente, geram riquezas extremamente importantes para seus Estados de origem, uma vez que os rendimentos no setor são expressivos e as rendas são reinvestidas internamente. Nesse sentido, elas podem ser um vetor importante para o desenvolvimento nacional. Segundo Victor (2013), embora após a crise global de 2008 as análises sobre NOCs tendam a enfatizar os custos que elas geram para a economia nacional, durante o surgimento das principais NOCs, os estudiosos do desenvolvimento econômico adotavam uma perspectiva oposta: a presença de um setor de energia, especialmente petrolífero, controlado pelo Estado poderia ajudar no desenvolvimento doméstico. Como exemplo, cita-se o caso da nacionalização da Aramco na Arábia Saudita, que acabou por liderar o desenvolvimento da indústria petroquímica daquele país.

$\mathrm{Na}$ atualidade, verifica-se que um dos principais desafios das NOCs é manter uma atuação de mercado eficiente sob o controle do Estado. Nesse sentido, Stevens (2008) observa que políticas públicas associadas a essas empresas, como o desenvolvimento de fornecedores locais (política de conteúdo local) e o investimento na formação de

\footnotetext{
${ }^{26}$ A doença holandesa decorre da excessiva valorização do câmbio, o que diminui os incentivos para o fortalecimento do setor industrial doméstico, tornando o país dependente do setor de matérias-primas. A expressão está relacionada à política do governo holandês adotada após a descoberta de enormes reservas de gás em Groningen, em 1959.
} 
profissionais altamente capacitados, podem ser um reforço importante para o crescimento de outros setores da economia, contribuindo, de alguma forma, para um futuro econômico sustentável quando as receitas de petróleo ou gás não estiverem mais disponíveis.

\subsection{As Particularidades do Mercado de Gás}

A Gazprom, embora esteja entre as quatro maiores produtoras de petróleo da Rússia (GAZPROM, 2016), tem sua atuação preponderante no setor de gás natural ${ }^{27}$. No segmento de petróleo, as empresas estatais russas não detêm a maioria do mercado, apesar da recompra de ativos que ocorreu na década de 2000 (assunto que será analisado no capítulo 3). O mercado de petróleo no país é dominado por dez empresas petrolíferas verticalmente integradas, que controlam $95 \%$ da produção de petróleo bruto e mais de $80 \%$ da capacidade de refino ${ }^{28}$, ainda que o transporte por oleodutos seja feito exclusivamente pela estatal Transneft.

O setor de gás, por sua vez, tem forte participação estatal. Mais da metade do consumo doméstico de energia primária provém do gás e a Gazprom é responsável por cerca de $86 \%$ da produção, além de controlar todo o sistema de escoamento e deter o monopólio de exportação. Ao mesmo tempo, a empresa é obrigada por lei a garantir o abastecimento para consumo doméstico das famílias e das indústrias (GOLDTHAU, 2008).

Em âmbito mundial, a Gazprom controla 20\% do mercado mundial e detém $25 \%$ das reservas mundiais de gás. Por essa razão, optamos, neste trabalho, por enfatizar a atuação do Gazprom no setor de gás. Com esse fim, destacaremos, nesta seção, as singularidades desse mercado que, embora compartilhe com o petróleo uma dinâmica similar de produção e precificação, possui diversas particularidades.

Em primeiro lugar, é preciso destacar que o mercado de gás é mais fragmentado que o de petróleo. Ainda não existe um mercado global de preços para o gás, mas três mercados regionais importantes: América do Norte, Europa e Ásia. Apenas 30\% do consumo mundial de gás provêm de importações, desse volume, 70\% chegam por meio de gasodutos. Assim, as importações de gás natural provêm principalmente de países

\footnotetext{
${ }^{27}$ O gás natural pode ser extraído a partir de um campo que produz petróleo bruto e gás ou a partir de um campo que contém predominantemente gás (conhecido como gás não associado). Na Rússia existem vastos reservatórios que produzem exclusivamente gás natural.

${ }^{28}$ O Estado russo controla cerca de $25 \%$ da produção de petróleo e cerca de $16 \%$ da capacidade de refino (GOLDTHAU, 2008).
} 
vizinhos. No caso do petróleo, apenas $40 \%$ do volume demando vem de produtores locais e regionais, a diferença é suprida por acordos feitos no mercado mundial (MITCHELL; MARCEL; MITCHELL 2012).

De modo geral, em escala global, as reservas de gás têm menor controle estatal do que aquelas de petróleo (apenas 53\% das reservas de gás estão sob o controle de governos, no caso do petróleo, 86\% das reservas pertencem aos Estados). Contudo, essa maior pulverização se deve à presença de grandes reservas de gás nos Estados Unidos, onde o controle privado é mais comum (MITCHELL; MARCEL; MITCHELL 2012; CLAES, 2013). Por outro lado, as reservas de gás estão mais concentradas em um menor número de países - Rússia, Irã e Catar detêm quase $60 \%$ das reservas ${ }^{29}$-, e nesses países a presença estatal é determinante.

Como a maior parte do gás é transportada por gasodutos, negociações entre países são tão importantes quanto o preço desse produto no mercado internacional. A falta de flexibilidade no transporte, com os gasodutos suscetíveis a sabotagens e desvios de fornecimento, exige maior alinhamento político entre os países envolvidos. Essa característica do mercado de gás torna muito mais eficaz um possível embargo a países dependentes desse combustível do que no caso do petróleo. Os consumidores de petróleo podem sempre recorrer a um mercado mundial mais bem estruturado e com maiores facilidades logísticas para suprir suas demandas em caso de emergência. Os consumidores de gás, entretanto, dispõem de poucas soluções alternativas no curto prazo e, a médio e longo prazo, elas envolvam custos substanciais de adaptação.

Conforme ressaltam Goldthau e Witte (2010), o mercado do gás tem sido liberalizado mais lentamente do que o de petróleo. Ainda que a expansão gás natural liquefeito $(\mathrm{GNL})^{30}$ tenha permitindo maior flexibilidade das cadeias de suprimento, a maior parte do fornecimento global de gás ainda é feita por meio de contratos rígidos, que requerem vínculos de longo prazo entre compradores e vendedores, bem como entre aqueles países por onde passam os gasodutos. Normalmente, devidos aos altos custos de infraestrutura e à demora no retorno dos investimentos, o planejamento para a construção

\footnotetext{
${ }^{29}$ A Rússia detém a maior reserva de gás do mundo, com mais de 30\%. No setor de petróleo, os países do Golfo Pérsico controlam quase 55\% das reservas, a Arábia Saudita controla 25,3\% e o Iraque $11,1 \%$ (YERGIN, 2012; WILCZEWSKI, 2008).

${ }^{30}$ A tecnologia do GNL é responsável por tornar o gás liquefeito, por meio da redução de sua temperatura a menos 160 graus Celsius, permitindo assim que o gás seja transportado em embarcações semelhantes a petroleiros (PIMENTEL, 2011).
} 
desses projetos precisa levar em consideração fatores como o risco político dos países envolvidos.

Uma diferença importante entre os mercados de petróleo e gás é o fato de o petróleo ser, geralmente, vendido em mercados "spot" (à vista), com negociações ocorrendo diariamente. Nesses casos, os contratos são principalmente de curto prazo: de três a seis meses. No caso do gás, em razão da necessidade de garantir ao exportador uma demanda futura, para que ele possa investir na logística de distribuição, predominam contratos de longo prazo, embora o tempo de duração dos novos contratos venha diminuindo gradualmente.

O aumento no uso do GNL poderá mudar essa dinâmica, devendo contribuir para o surgimento de um mercado global de gás. A ampliação no uso desse combustível tem contribuído para o aumento expressivo de negociações de contratos spot também no mercado de gás. Mesmo assim, esse tipo de contrato para o setor de gás ainda é marginal em escala mundial, concentrando-se no mercado norte-americano. Na Europa e nas demais partes do mundo, os contratos para fornecimento de gás têm duração entre 15 e 25 anos. Esses contratos contêm cláusulas do tipo "take-or-pay", que obriga o comprador a ter de pagar por um determinando volume de gás, a um preço já estabelecido, independentemente de ocorrerem mudanças nas suas necessidades de consumo ou nos preços no mercado mundial (PROEDROU, 2012).

Estima-se que, a partir de 2035, o GNL se tornará o principal meio de transporte de gás, contribuindo para uma maior homogeneização dos preços em escala mundial. $\mathrm{O}$ comércio desse tipo de combustível já cresce duas vezes mais rápido do que o consumo de derivados de petróleo. Nesse contexto, é estimado que sua parcela na matriz energética mundial cresça de 10\% em 2014 para 15\% em 2035 (BP, 2016).

Cabe destacar, contudo, que a infraestrutura para o transporte do GNL "exige a construção de caríssimos terminais portuários especializados, além de implicar consideráveis perdas de eficiência referentes aos custos de refrigeração do gás" (PIMENTEL, 2011, p. 75). Assim, os altos custos de capitais para a entrada no mercado de GNL constitui uma barreira para a expansão desse mercado.

O aumento da participação do gás na matriz energética mundial é ainda reforçado pelo desenvolvimento das reservas de gás de folhelho (comumente conhecido com gás de xisto $^{31}$ ) (BP, 2016). A descoberta do folhelho transformou as perspectivas norte-

\footnotetext{
${ }^{31} \mathrm{O}$ folhelho é uma rocha de origem sedimentar da qual se pode extrair petróleo e gás. Nas últimas décadas, os Estados Unidos investiram na melhoria da tecnologia para extração desta matéria-prima, o que
} 
americanas sobre suas fontes de energia, pois esses recursos podem garantir o abastecimento do país por mais de cem anos (YERGIN, 2012). Em âmbito mundial, as reservas também são significativas, especialmente na China. Estima-se que seu uso cresça cerca de 5\% ao ano, passando de $11 \%$ da matriz energética mundial, em 2014, para quase 24\% em 2035 (BP, 2016).

Um dos incentivos para a ampliação do uso do gás natural é a possibilidade de ele ser utilizado como um combustível de transição para um modelo econômico mais sustentável, uma vez que é menos poluente que o petróleo e o carvão. Sua combustão mais eficiente se traduz em uma queda considerável da emissão de carbono (GHALEB, 2011). Políticas públicas que buscam coibir o uso de combustíveis altamente poluentes podem favorecer o uso do gás, ainda que, no longo prazo, seu uso também possa ser restringido em razão de políticas que promovam o uso de combustíveis renováveis e ainda menos poluentes (MITCHELL; MARCEL; MITCHELL 2012).

O gás natural é atualmente a terceira maior fonte de energia do mundo em termos de consumo e produção e estima-se que substituirá o carvão como o principal combustível para a geração de energia elétrica nos próximos anos. O consumo global de gás cresce mais rapidamente do que qualquer outra fonte de energia primária fóssil, com projeções mostrando que o consumo dobrará nas próximas duas décadas. Se essa taxa de crescimento permanecer constante, o gás natural se tornará a fonte de energia primária mais importante do mundo até 2050, superando tanto o carvão quanto o petróleo (GHALEB, 2011).

No que concerne a preços, historicamente o preço do gás (em uma base equivalente em energia) acompanha o preço do petróleo, sendo o gás geralmente vendido com um desconto sobre preço do petróleo, em razão da maior dificuldade de transporte, armazenamento e distribuição. A precificação com base no petróleo se deve ao fato de que quando o gás começou a ser transacionado no mercado internacional, na década de $1960^{32}$, não havia uma maneira de definir seu preço. Como o gás era usado como um substituto do petróleo em aquecimento e em geração de energia, optou-se por ligar seu preço ao do petróleo. No entanto, o aumento na oferta de gás no mercado europeu no final

possibilitou ao país voltar a liderar a produção de gás natural de 2012 em diante. A Rússia também possui grandes formações rochosas de folhelho no Ártico e na Sibéria Ocidental, mas ainda são pouco exploradas. ${ }^{32}$ Em 1959, descobriu-se o gigante campo de gás de Groningen, na Holanda. O gás presente nesse campo passou a ser escoado para Bélgica, Alemanha e França em meados da década de 1960, marcando o início das exportações de gás na Europa Ocidental. 
da década de $2000^{33}$, em um contexto de preços de petróleo bastante altos, acabou por gerar um princípio de dissociação entre as duas cotações, o que poderia ensejar o surgimento de um mercado de preços específico para o gás (THE ECONOMIST, 2014).

O gráfico seguinte mostra a relação entre os preços do petróleo e do gás ao longo da história recente:

\section{Figura 2- Comparação dos Preços do Petróleo e do Gás}

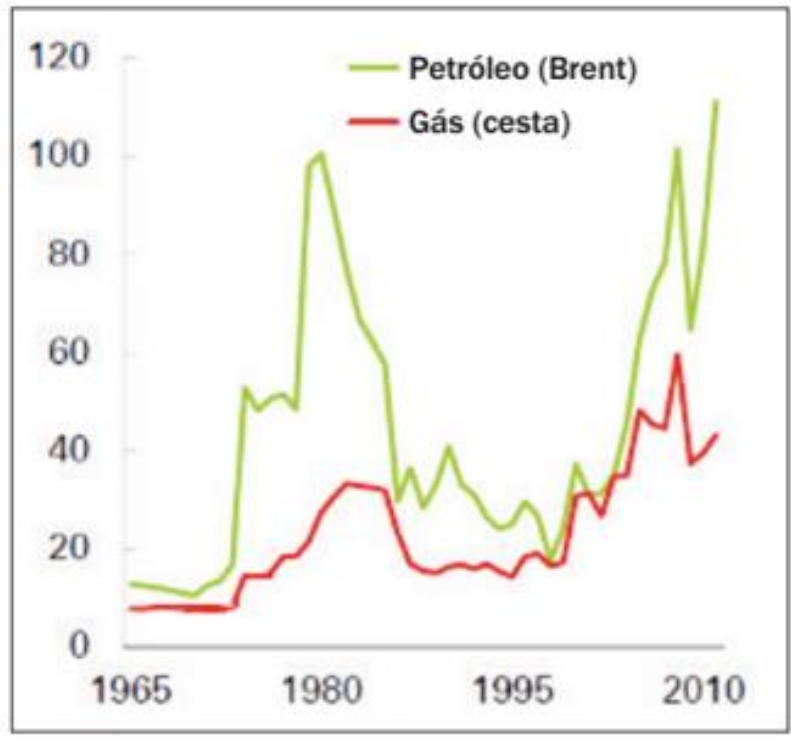

Fonte: BP Energy Outlook 2030

Segundo Stevens (2016), o mercado de gás é menos lucrativo do que o de petróleo, uma vez que não há uma organização como a Opep controlando a produção com o objetivo de manter os preços em determinado patamar. No entanto, não se descarta a possibilidade de os principais produtores de gás criarem iniciativas para manter seu poder de mercado e a lucratividade de seus contratos.

Em 2001, por proposta da Rússia, foi criado um grupo de concertação entre os países exportadores de gás, o Gas Exporting Country Forum (GECF) ${ }^{34}$ (TSYGANKOV, 2016), o que alguns analistas denominaram de a "Opep do gás". O grupo é composto por doze países, incluindo os maiores exportadores de gás do mundo: Rússia, Irã, Argélia e Catar. Em 2008, a GECF, que vinha operando como um grupo informal, tornou-se uma organização internacional. No entanto, os encontros do grupo, que ocorrem anualmente,

\footnotetext{
${ }^{33}$ A partir de 2008, GNL do Catar for redirecionado dos Estados Unidos para a Europa, pois a demanda no mercado americano caiu em razão do aumento da produção do gás de folhelho (THE ECONOMIST, 2014). ${ }^{34}$ Os países-membros da GECF são: Argélia, Bolívia, Egito, Guiné Equatorial, Irã, Líbia, Nigéria, Catar, Rússia, Trinidad e Tobago, Emirados Árabes Unidos e Venezuela. São membros observadores: Azerbaijão, Iraque, Cazaquistão, Holanda, Noruega, Oman e Peru. A sede fica no Catar.
} 
estão mais ligados à troca de informações sobre assuntos como tecnologia e pesquisa do que sobre cotas de produção ou acordos de preço (GOLDMAN, 2008).

Devido às peculiaridades do mercado de gás, como a prevalência de contratos de longo prazo e a regionalização dos mercados, uma cartelização desse mercado nos moldes da Opep é mais difícil. Não obstante, ela poderia se materializar no que diz respeito ao desenvolvimento do mercado, a sequência e o calendário de exploração e produção, bem como nos acordos sobre rotas de exportação (LESAGE; VAN DE GRAAF; WESTPHAL, 2010).

Desde sua primeira reunião, os membros do GECF vêm emitindo comunicados repudiando o termo "Opep do gás”. Após a institucionalização do grupo, a primeira reunião foi realizada em Doha, no Catar, em novembro de 2011. O evento resultou em uma declaração sobre a importância do gás natural para economia global, sobre a necessidade de coordenação dos países exportadores, sobre a importância do preço justo para o gás, bem como sobre o princípio de distribuição equilibrada dos riscos entre produtores e consumidores.

Estima-se que, sem a participação de produtores importantes de gás, como Estados Unidos e Canadá, a organização tenha pouco poder de barganha. Os países membros do GECF são responsáveis por apenas $14 \%$ do gás consumido no mundo (GOLDMAN, 2008), embora detenham 67\% reservas mundiais de gás e $40 \%$ da infraestrutura de transporte (GECF, 2016). Os membros da Opep, em comparação, são responsáveis por mais de 35\% das exportações de petróleo do mundo. Não obstante, um controle de preços do gás por parte dos países da GECF poderia ser eficaz em relação à Europa, uma vez que Rússia e Argélia são responsáveis por cerca de 44\% das exportações de gás natural para o continente europeu (GOLDMAN, 2008).

Em outubro de 2008, Rússia, Irã e Catar deram um passo à frente do GECF e formaram um novo mecanismo de cooperação, o qual ficou conhecido como a "troika do gás” ou “G3 do gás”. Por meio desse mecanismo, esses países concordaram em realizar reuniões regulares - três ou quatro vezes por ano - para discutir questões-chave sobre a evolução do mercado de gás. Na ocasião, Europa e os Estados Unidos alertaram que a formação desse novo grupo poderia representar um risco para a segurança energética global e criar espaço para a manipulação de preços (HAFEZI, 2008). Mais uma vez, no entanto, indaga-se se seria possível maior cartelização no mercado de gás. Para Wilczewski (2008), o elevado consumo interno da Rússia torna o país incapaz de desempenhar um papel de moderador dentro da nova organização, algo semelhante ao 
que os sauditas desempenham na Opep. Além disso, a Opep tem a vantagem geográfica de ter grande parte de suas reservas concentrada no Oriente Médio, um cartel de gás seria geográfica e culturalmente muito diverso e, portanto, mais suscetível a desacordos. Adicionalmente, Irã e Catar, embora possuam reservas consideráveis, desempenham atualmente papel pouco expressivo no mercado internacional de gás.

Assim, especula-se se o "G3 do gás" seria uma estratégia russa para manter o gás do Irã e do Catar longe do mercado europeu (WILCZEWSKI, 2008). É questionável se a Rússia estaria disposta, de fato, a subordinar suas ações a um grupo de controle de produção. Goldman (2008) observa que Moscou jamais quis ingressar na Opep, uma vez que preferia manter sua autonomia de produção, o que permitiu à URSS aumentar suas exportações e se beneficiar de preços mais elevados em ocasiões em que a Opep reduziu a produção, como em 1973. Em 1974, a União Soviética se tornou a maior produtora mundial de petróleo. 


\section{Petróleo e Gás na Rússia e a Construção da Gazprom}

\subsection{A Inserção da Rússia no Mercado Mundial de Energia}

A Rússia, primeiro país em extensão territorial do mundo, dispõe de vastos recursos minerais. Entre os mais importantes para sua economia, estão o petróleo e o gás. Este país é o maior exportador mundial de gás - embora os Estados Unidos tenham assumido a liderança na produção desta matéria-prima em 2012, em razão da exploração do gás de folhelho (ou xisto) -, e o segundo maior produtor e exportador de petróleo, atrás apenas da Arábia Saudita (IEA, 2015). O setor é responsável por cerca de 25\% do produto nacional bruto da Rússia, 50\% de sua receita orçamentária e quase $70 \%$ de sua receita de exportação (YERGIN, 2012; GUSTAFSON, 2012; AALTO, 2016; EIA, 2014).

A exploração de petróleo tem desempenhado um papel importante na economia russa desde o século XIX, com implicações em sua política doméstica e externa desde então. Ainda no início daquele século, o reconhecimento da importância estratégica do petróleo pelas autoridades czaristas fez com que o Império Russo empreendesse esforços militares para obter controle da região de Baku (atual capital do Azerbaijão), então sob o domínio do Império Otomano. Em 1898, a Rússia já era a principal produtora mundial em razão do petróleo produzido em Baku, posição que manteve até 1902 (GÖKAY, 1999). De 1890 a 1900, a produção triplicou na região, sendo o Império Russo responsável por mais de $40 \%$ da produção mundial no começo do século XX, o que atraiu o interesse de investidores estrangeiros para a região, encabeçados pela família Nobel, seguida pela Rothschild e, mais tarde, por empresas britânicas (BAHGAT, 2011).

Durante a Guerra Civil Russa (1918-1921), lideranças comunistas (formadas principalmente por descendentes russos e armênios) passaram a apoiar o movimento revolucionário. Paralelamente, lideranças nacionalistas locais declararam a independência do Azerbaijão, assinando acordos com petroleiras ocidentais. No entanto, o território foi recuperado pelo Exército Vermelho e incorporado à União Soviética em 1922, que pôs fim a todos os contratos firmados pelo governo nacionalista do Azerbaijão com as petroleiras do Ocidente (GÖKAY, 1999).

Assim, a Revolução Russa derivou na expropriação dos ativos de todas companhias petrolíferas que atuavam nas regiões sob o domínio soviético, ensejando um boicote por parte das “Sete Irmãs". No entanto, por volta de 1923, a URSS já se recuperara da queda de produção causada pela guerra civil e buscou voltar ao mercado mundial de 
petróleo, oferecendo concessões de exploração. A primeira empresa a se esquivar do boicote e firmar acordo com Moscou foi a Royal Dutch-Shell. Segundo Gökay (1999), Lenin considerou até mesmo transferir o controle da indústria petrolífera do CáspioCáucaso para a Shell. Na época, o governo soviético buscava pôr em prática sua Nova Política Econômica (Novaya Ekonomiceskaya Politika - NEP), que restabelecia algumas práticas capitalistas vigentes antes da Revolução, a fim de permitir que a URSS saísse da grave crise econômica em que se encontrava (SCHUTTE, 2011).

Durante a vigência NEP, Moscou conduziu longas e complicadas negociações com várias empresas estrangeiras para o desenvolvimento dos campos de Baku. No entanto, quando Lenin morreu, em 1924, a NEP foi sendo gradualmente abandonada. Todas as negociações com as empresas estrangeiras finalmente se encerram em 1927, ano em que Stalin completou a consolidação de seu poder no Politurbo, o que pôs fim a todas as esperanças de assistência externa, crédito e cooperação econômica com o Ocidente (GÖKAY, 1999).

A partir do período stalinista (1927-1953), colocam-se em práticas as propostas de planejamento central, planos quinquenais e autossuficiência econômica - o chamado “socialismo em um só país”. Nesse período, a indústria de petróleo soviética cresceu abaixo da média mundial e, após o golpe contra Mossadegh no Irã, em 1953, que derivou na interrupção do acesso da URSS ao petróleo iraniano, as indústrias soviéticas passaram a enfrentar dificuldades para obter combustíveis e seguir produzindo (KOTKIN, 2008).

A partir da década de 1950, porém, a descoberta de vastas reservas de petróleo na região do Urais-Volga (ver Figura 3) faz a produção aumentar significativamente, fazendo dessa região a principal produtora de petróleo na União Soviética, ultrapassando o Cáucaso. De 1961 a 1969, a URSS passou de importador a exportador líquido de petróleo. As exportações dessa matéria-prima tornaram-se o principal artigo da balança comercial soviética e passaram então a servir como meio para alavancar o desenvolvimento econômico doméstico. Entre 1960 e 1964, é construído o oleoduto Druzhba ("Amizade"), que passa a transportar o petróleo da região do Urais-Volga até Polônia, Hungria, Tchecoslováquia e Alemanha Oriental. Em 1970, uma extensão deste gasoduto chegou até Viena (CANTONI, 2015; POUSSENKOVA, 2010; HEINRINCH, 2014; KOTKIN, 2008).

Em outubro de 1960, Moscou firmara um acordo inovador de fornecimento de petróleo com a italiana ENI. O petróleo soviético seria intercambiado por produtos tecnológicos, como borracha sintética, tubos de aço e outros produtos italianos. Tal 
acordo ficou conhecido como "oil for pipes" ("petróleo por tubos"). Conforme observa Goldstein (2009), esse compromisso proporcionou à ENI adquirir petróleo pela metade do preço vigente no mercado mundial, tornando a Itália o segundo maior consumidor de petróleo soviético, atrás apenas da República Popular da China.

Segundo Gaidar (2007), a União Soviética aumentou sua participação no mercado mundial por meio da prática de dumping. No seu contrato de fornecimento de petróleo para a Europa Ocidental, particularmente para a Itália, os preços do petróleo soviético eram aproximadamente metade do que se praticava no mercado internacional na década de 1960, o que contribuiu para a queda dos preços mundiais nesse período.

A volta da URSS ao mercado de petróleo, por sua vez, gerou temores de que ela pudesse desestabilizar o arranjo criado pelas “Sete Irmãs”. O governo italiano sofreu forte pressão contrária ao acordo por parte de Washington. Alegava-se que esses equipamentos poderiam ajudar no fortalecimento econômico e militar da União Soviética, prejudicando os interesses do bloco ocidental. Em uma entrevista concedida à jornalista norteamericana Ernestine Adams, em dezembro de 1960, Enrico Mattei, presidente da ENI, destacou que a URSS já recebia equipamentos sofisticados de empresas britânicas e da Alemanha Ocidental - como a Krupp/Mannesmann - os quais poderiam ser muito mais ameaçadores para a segurança dos países da Organização do Tratado do Atlântico Norte (OTAN) do que o acordo entre italianos e soviéticos (CASTRONOVO, 2015). De fato, entre 1958 e 1962, as exportações alemãs de tubos de aço para a União Soviética cresceram de 3,2 mil toneladas para 255,4 mil toneladas (HÖGSELIUS, 2013)

Em fevereiro de 1961, a ENI assinou um protocolo adicional ao acordo de 1960, cobrindo o período de 1962 a 1965 (CANTONI, 2015). Em 1962, a Otan impôs um embargo à venda de equipamentos relacionados à indústria de hidrocarbonetos à URSS. Apesar de tal medida, o consumo de petróleo soviético na Europa não diminuiu. $\mathrm{O}$ embargo foi retirado em 1966 (PEROVIC, 2016).

\subsection{A Expansão do Mercado de Gás e a Criação da Gazprom}

No que se refere ao gás, a produção soviética teve início com a exploração dos campos de Saratov, na região do Volga, e de Dashava, na Ucrânia. Nas décadas de 1940 e 1950, gasodutos foram construídos para que esses campos pudessem abastecer as três principais cidades do bloco comunista - Moscou, Leningrado (atual São Petersburgo) e Kiev -, bem como outras regiões industriais. No final da década de 1950, novos gasodutos 
foram construídos com a finalidade de levar gás do Azerbaijão aos demais países do Cáucaso (Geórgia e Armênia) (HÖGSELIUS, 2013).

Em meados da década de 1960, no entanto, são descobertos os gigantes campos de gás na Sibéria Ocidental: Urengoy, Medvezh“ye e Yamburg - conhecido como "os três grandes" - fazendo dessa região a principal produtora de gás e diminuindo a importância relativa das demais áreas. Em seguida, na década de 1970, novos campos são descobertos na península de Yamal, no extremo norte da Sibéria Ocidental, consolidando a região da Sibéria como o principal centro produtor de gás e petróleo da URSS, tornando o bloco soviético também um importante exportador de gás (STERN, 2005).

\section{Figura 3 - Mapa das Principais Regiões Produtoras de Gás na Rússia}

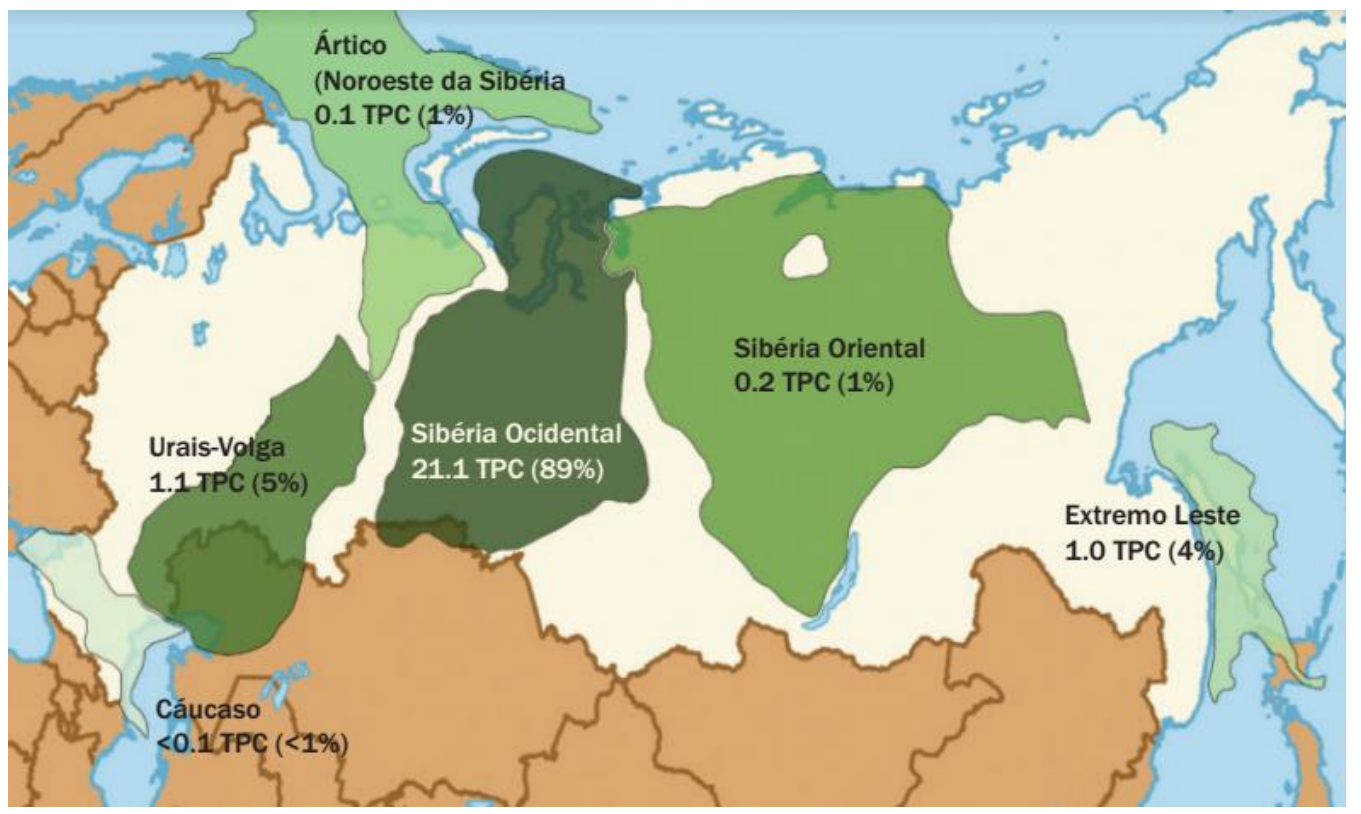

Elaborado pela autora. Fonte: EIA (2013)

*TPC (Trilhões de Pés Cúbicos)

Apesar da imensa riqueza em campos de gás, o estabelecimento de uma rede de gasodutos unificada, que compreendesse todo o território soviético, foi prejudicado pela falta de disponibilidade de tubos de aço de alta qualidade, de compressores e de uma variedade de outros materiais, máquinas e equipamentos. Como a União Soviética era uma economia planejada, esses bens nem sempre estavam prontamente disponíveis. Além disso, a fabricação de tubos para gasodutos - os quais precisam ser fortes o suficiente para resistir a pressões muito altas - era tecnologicamente muito mais desafiadora do que a de tubos para oleodutos, indústria na qual os soviéticos já tinham alguma experiência (HÖGSELIUS, 2013). 
Em 1967 é construído o gasoduto Bratstvo (Fraternidade) ligando, inicialmente, os campos de gás da Ucrânia até a Tchecoslováquia ${ }^{35}$. Em 1968, a estatal austríaca OMV negociou com Moscou para obter acesso ao gás que chegava à Tchecoslováquia - apenas cinco quilômetros separavam o ponto final do gasoduto em território tcheco da Áustria -, dando início ao primeiro acordo "gas for pipes" ("gás por tubos"). Por meio desse esquema, a Áustria passou a oferecer financiamentos para a construção e ampliação de gasodutos soviéticos, em troca do acesso ao gás (HÖGSELIUS, 2013).

O início das exportações de gás para a Áustria ocorreu dez dias após a invasão da Tchecoslováquia por tropas soviéticas, no episódio conhecido como "Primavera de Praga"36. Mesmo nesse contexto de forte tensão política, o prazo para o início das exportações não foi adiado. Isso ocorreu, sobretudo, porque era do interesse de Moscou demonstrar que o abastecimento seria mantido mesmo em momentos de crise. Por outro lado, o conflito na Tchecoslováquia acabou por adiar as negociações que envolviam a extensão de gasodutos também para outros países do bloco ocidental, como Itália e França (HÖGSELIUS, 2013).

Na década de 1970, no contexto da Ostpolitik de Willy Brandt - política que buscava reduzir as tensões da Guerra Fria, normalizando as relações com o bloco socialista por meio da criação de interesses comuns entre Oriente e Ocidente -, o chanceler da República Federal da Alemanha (RFA) engajou-se diretamente nas negociações para construção de um novo gasoduto ligando os campos de gás da Sibéria até a Europa Central, tendo obtido o apoio dos representantes de Itália e França, países que também seriam beneficiados pelo aumento da oferta de gás no continente. Assim como ocorrera no acordo com a Áustria, a RFA (e também a Itália, em menor escala) ofereceu linhas de crédito, suporte técnico e tubos de largo diâmetro aos soviéticos em troca do recebimento de gás.

Em 1973, cinco membros do bloco capitalista - Áustria, Alemanha, Itália, Finlândia e França - já haviam assinado contratos com a União Soviética para o fornecimento de gás e outros países demonstravam interesse em seguir o mesmo caminho.

\footnotetext{
${ }^{35}$ Mais tarde, o Bratstvo foi também estendido no sentido leste, alcançando os ricos campos de gás da Sibéria.

${ }^{36}$ Entre 20 e 21 de agosto de 1968, tropas do Pacto de Varsóvia invadiram a Tchecoslováquia - atualmente República Tcheca e Eslováquia - depois que Alexander Dubcek assumiu o cargo de secretário-geral do Partido Comunista tcheco e realizou uma série de reformas que desagradaram a Moscou, entre elas estavam o fim do monopólio político do Partido Comunista e uma maior aproximação com os países do bloco ocidental.
} 
Para tanto, planejou-se a construção de um novo gasoduto, o Urengoy-Uzhgorod, o qual seria construindo seguindo a mesma rota do gasoduto Bratstvo.

\section{Figura 4 - Mapa dos Principais Gasodutos Ligando a Rússia à Europa}

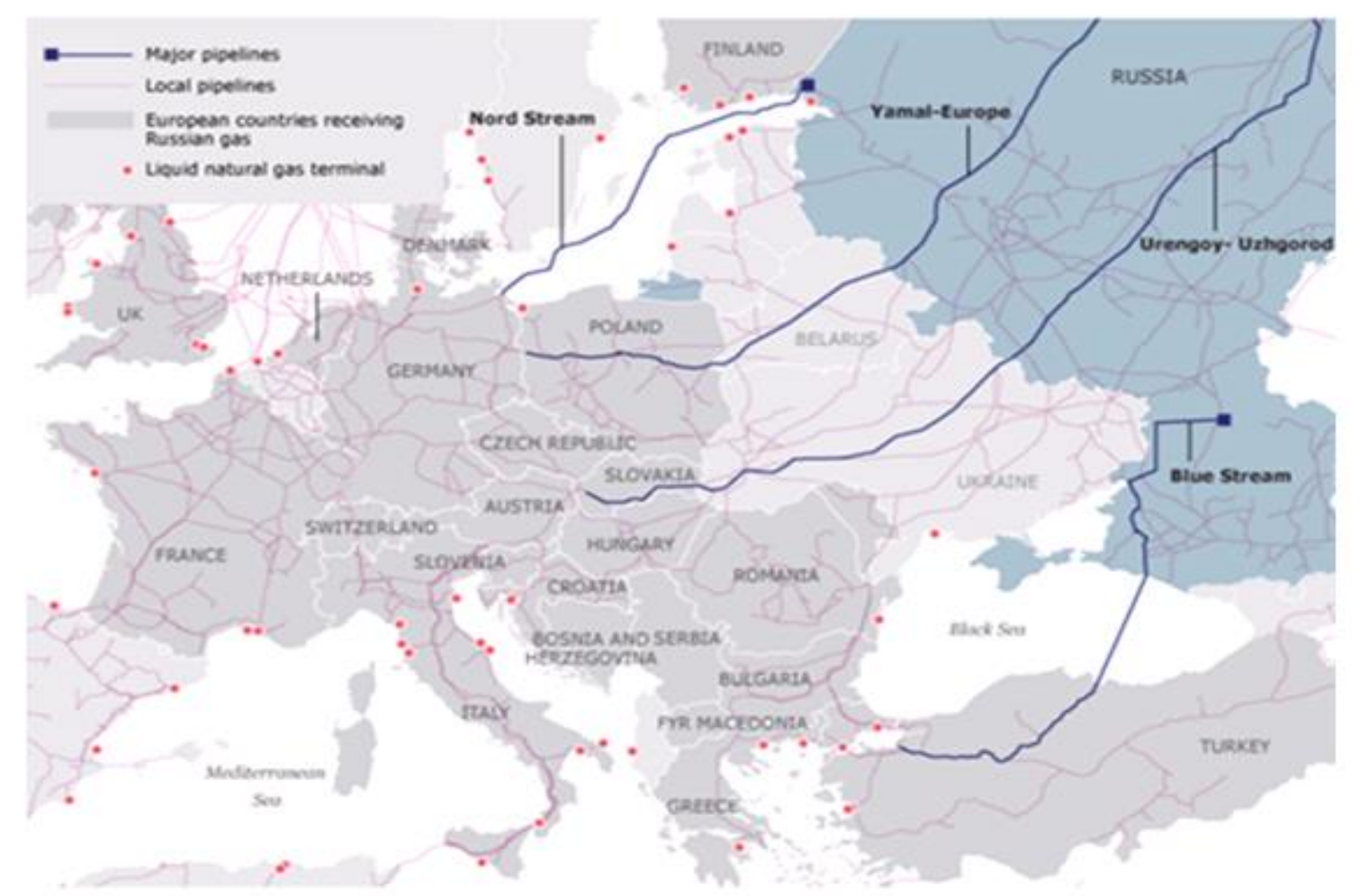

Fonte: TASS

Högselius (2013) observa que esse extraordinário dinamismo das relações entre Europa e URSS tinha surgido há apenas alguns anos e era essencialmente o resultado da combinação de duas tendências-chave: um crescimento sem precedentes na popularidade do gás natural como fonte de energia ${ }^{37}$ e uma nova onda de tentativas de aproximação entre os blocos Leste e Oeste. A perspectiva de oportunidades econômicas e políticas resultantes da importação do gás soviético fizeram com que uma série de atores se entusiasmasse com a possibilidade de interconectar a infraestrutura de gasodutos da URSS com a da Europa Ocidental.

\footnotetext{
37 No início da década de 1970, os países da Europa Ocidental estavam bastante preocupados com as incidências de chuva ácida e buscavam fontes de energia menos poluentes. Após a Conferência das Nações Unidas sobre Meio Ambiente Humano (CNUMAH) de 1972, alguns deles impuseram restrições ao uso de combustíveis que geravam dióxido de enxofre. Na ocasião, o gás natural foi apontado como tendo excelentes propriedades ambientais, uma vez que sua combustão quase não gerava dióxido de enxofre, mas apenas água e dióxido de carbono (que, à época, se acreditava menos danoso ao meio ambiente) (HÖGSELIUS, 2013).
} 
O Primeiro Choque do Petróleo, no fim de 1973, aumentou o debate político sobre a conveniência de se receber o gás soviético. Par alguns, ele era parte do problema, pois representava a arriscada dependência europeia de combustíveis fósseis importados e os riscos de interrupções com base em interesses políticos; para outros, era parte da solução, porquanto ajudava na diversificação das fontes de energia. No final, a crise no Oriente Médio acabou por reforçar a aproximação Leste-Oeste na área energética (HÖGSELIUS, 2013).

Em 1974, a URSS se tornara o maior produtor mundial de petróleo (GÖKAY, 1999). No final da década de 1970, no entanto, sua produção de petróleo dava sinais de já ter atingindo seu ponto máximo de produção. Esperava-se, por conseguinte, que a quantidade produzida começasse a diminuir gradualmente. Nesse cenário, o gás foi visto como um sucessor natural para o petróleo como a principal matéria-prima de exportação do bloco soviético, ainda que não oferecesse o mesmo grau de flexibilidade. No início da década de 1980, a entrada em produção dos novos campos de gás da Sibéria Ocidental tornaria a União Soviética o maior produtor mundial, ultrapassando os Estados Unidos.

Gaidar (2007) e Kotkin (2008) observam que a exportação de hidrocarbonetos era uma essencial fonte de receitas para a URSS. Durantes os dois choques do petróleo (1973 e 1979), o aumento nos preços beneficiou substancialmente as finanças do bloco soviético, adiando a crise econômica que ocorreria nas décadas seguintes. As receitas do setor possibilitaram a supressão das recorrentes dificuldades para a importação de alimentos e proporcionou um aumento nas aquisições de equipamentos e de bens de consumo. Além disso, garantiu uma base financeira para que os soviéticos prosseguissem na corrida armamentista e na busca de paridade nuclear com os Estados Unidos; além de permitir a realização de ações de política externa arriscadas como a guerra no Afeganistão, em 1979.

A ascensão de Ronald Reagan a presidência dos Estados Unidos, em 1981, representou, entretanto, um importante obstáculo aos planos de construção do gasoduto Urengoy-Uzhgorod. Reagan aumentou os investimentos na indústria bélica norteamericana tendo como um dos objetivos minar as reservas econômicas soviéticas, impelindo Moscou a investir mais recursos na manutenção da paridade bélica com a potência rival. Nesse contexto, a possibilidade de que uma nova fonte de receita pudesse financiar o desenvolvimento militar soviético era contrária aos interesses de Washington. A fim de pressionar os europeus, o novo governo americano alertou que a maior dependência do gás soviético tornaria a Europa mais dependente do bloco socialista, 
advertindo que os europeus ficariam suscetíveis a chantagens de Moscou, que poderia ameaçar desligar o fornecimento de gás em momentos de crise (YERGIN, 2012).

Os defensores do novo gasoduto, em contrapartida, alegavam que, apesar da possibilidade de um corte no abastecimento, os soviéticos também tinham interesse econômico em continuar fornecendo gás para a Europa, até mesmo para seguir se financiando e adquirindo os equipamentos de alta tecnologia que eram necessários para suprir sua própria indústria de energia. Como nas negociações anteriores, o fornecimento de gás seria o pagamento pelo recebimento de tubos de aço de maior diâmetro e outros equipamentos essenciais (HÖGSELIUS, 2013).

Como os europeus se mantiveram firmes na decisão sobre a construção de um novo gasoduto, a administração Reagan contra-atacou propondo outras fontes de energia, como maior acesso ao carvão norte-americano, tecnologia nuclear e mesmo a construção de um gasoduto paralelo. Como a infraestrutura necessária para fornecer gás natural é muito cara, a construção de um gasoduto concorrente acabaria por frustrar a viabilidade econômica de um segundo projeto. Diante da determinação dos europeus em seguir em frente com o gasoduto Urengoy-Uzhgorod, Washington impôs um embargo unilateral proibindo empresas norte-americanas e europeias de exportar equipamento para a construção do gasoduto que utilizassem tecnologia americana (HÖGSELIUS, 2013; YERGIN, 2012).

No entanto, mesmo a aliada mais próximo de Reagan, a primeira ministra britânica Margaret Thatcher, se opôs a determinação de Washington. A Comissão das Comunidades Europeias (CEE) calculou que o cumprimento do embargo privaria empresas europeias de 8,5 bilhões de dólares em receitas - e isto em um momento em que a região enfrentava recessão e altos índices de desemprego. Insistindo que o novo gasoduto não representava uma ameaça à segurança, a possível adesão ao embargo foi apontada como destrutiva e inútil. Em uma carta conjunta enviada aos departamentos de Estado e de Comércio dos Estados Unidos em agosto de 1982, a CEE declarou ilegal o embargo. Tal política foi ainda apoiada por uma resolução adotada pelo Parlamento Europeu. Os embarques de material para a URSS não cessaram. Finalmente, a administração Reagan foi obrigada a reconhecer a inutilidade do embargo e, em novembro de 1982, ele foi revogado (HÖGSELIUS, 2013).

Ressalte-se, ainda, que mesmo acontecimentos políticos que geraram grande comoção no Ocidente - como a invasão do Afeganistão em 1979 e a supressão do sindicato Solidariedade na Polônia em 1981 - não fizerem com que os europeus 
desistissem das negociações para a construção de um novo gasoduto com os soviéticos. Em 1983, o gasoduto Urengoy-Uzhgorod foi finalmente inaugurado. O fluxo de gás soviético para a Europa mais que duplicou em uma década (HÖGSELIUS, 2013; YERGIN, 2012; SMIL, 2015).

Esse fato, no entanto, não impediu o colapso econômico da URSS. Após 1986, a redução significativa nos preços dos hidrocarbonetos no mercado internacional (ver Figura 1) impactou seriamente a economia soviética, que viu suas reservas internacionais minguarem, impossibilitando até mesmo a importação de produtos básicos. Gaidar (2007) aponta o mês de setembro de 1985 como o marco da derrocada econômica. Segundo este autor, não havia dinheiro nem mesmo para a importação de alimentos. Primeiramente as autoridades monetárias venderam quase todo o ouro disponível, depois passaram a pedir empréstimos aos países ocidentais.

Para muitos analistas, o colapso dos preços foi decisivo para a desintegração econômica e política da União Soviética. O fornecimento de energia para a Europa Ocidental era responsável por cerca de $80 \%$ dos ganhos soviéticos em moeda forte (o petróleo sozinho era responsável por 60\%). Estima-se que Moscou tenha perdido mais de 60 bilhões de dólares em receitas entre 1985 e 1989 (STENT, 1999). No entanto, conforme observa Gaidar (2007), é mais provável que a queda nos preços tenha sido um golpe final em um sistema já decadente. Grandes transformações simultâneas desencadearam um processo de enfraquecimento e, finalmente, de implosão do bloco socialista.

Em dezembro de 1991, os presidentes de Ucrânia, Belarus e da própria Rússia, firmaram os acordos de Belavezha, o qual estabeleceu a saída desses países da União Soviética e criação da Comunidade dos Estados Eslavos - mais tarde transformada na Comunidade de Estados Independentes $(\mathrm{CEI})^{38}$. No fim daquele mês, mais oito repúblicas soviéticas se juntaram a CEI. Finalmente, no Natal de 1991, Mikhail Gorbachev renunciou à presidência da URSS, que foi oficialmente dissolvida no dia seguinte. $\mathrm{O}$

\footnotetext{
38 A Comunidade dos Estados Independentes (CEI) foi fundada, inicialmente, por Rússia, Belarus e Ucrânia, com o nome de Comunidade dos Estados Eslavos. Mas, devido ao interesse das demais exrepúblicas soviéticas de fazerem parte do bloco, o grupo converteu-se na CEI. Atualmente fazem parte da Comunidade: Rússia, Ucrânia, Belarus, Cazaquistão, Quirguistão, Tadjiquistão, Turcomenistão, Uzbequistão, Moldávia, Azerbaijão e Armênia. Os países bálticos (Lituânia, Estônia e Letônia) nunca ingressaram na CEI. A Geórgia, que havia ingressado somente em 1992, saiu do grupo em 2008 devido aos conflitos com a Rússia sobre as regiões separatistas da Abecásia e da Ossétia do Sul.
} 
desmembramento da URSS resultou no aparecimento de quinze novos Estados e, consequentemente, de novos atores no mercado de energia ${ }^{39}$.

\subsection{Yeltsin e as Privatizações}

Boris Yeltsin, presidente da Rússia a partir de 12 de junho de 1991, governou o país durante um período de enormes dificuldades econômicas, políticas e sociais. A década de 1990 foi marcada na Rússia por crises financeiras e pela drástica redução do bem-estar social. O Produto reduziu-se à metade ao final de década de 1990, tendo apresentado resultados negativos em todos os anos salvo em 1997, conforme demonstram os gráficos a seguir:

39 Os novos países que surgiram após o colapso da URSS foram: Azerbaijão, Armênia, Belarus, Cazaquistão, Estônia, Geórgia, Letônia, Lituânia, Moldávia, Quirguistão, Rússia, Tadjiquistão, Turcomenistão, Ucrânia e Uzbequistão. 
Figura 5 - Gráfico dos Preços Spot (Brent/FOB) de 1990 a 2015

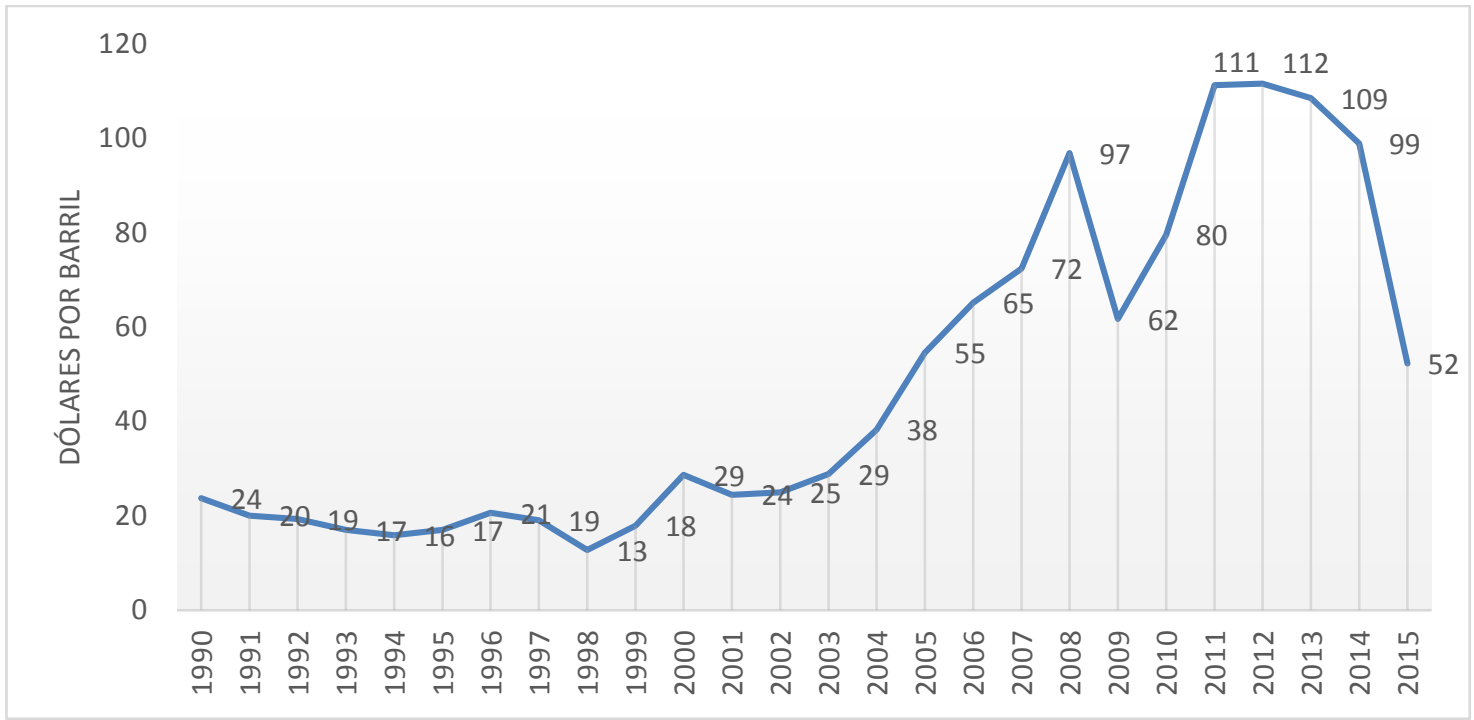

Elaboração Própria/Fonte: EIA

Figura 6 - Gráfico da Variação do Produto Nacional Russo de 1990 a 2015

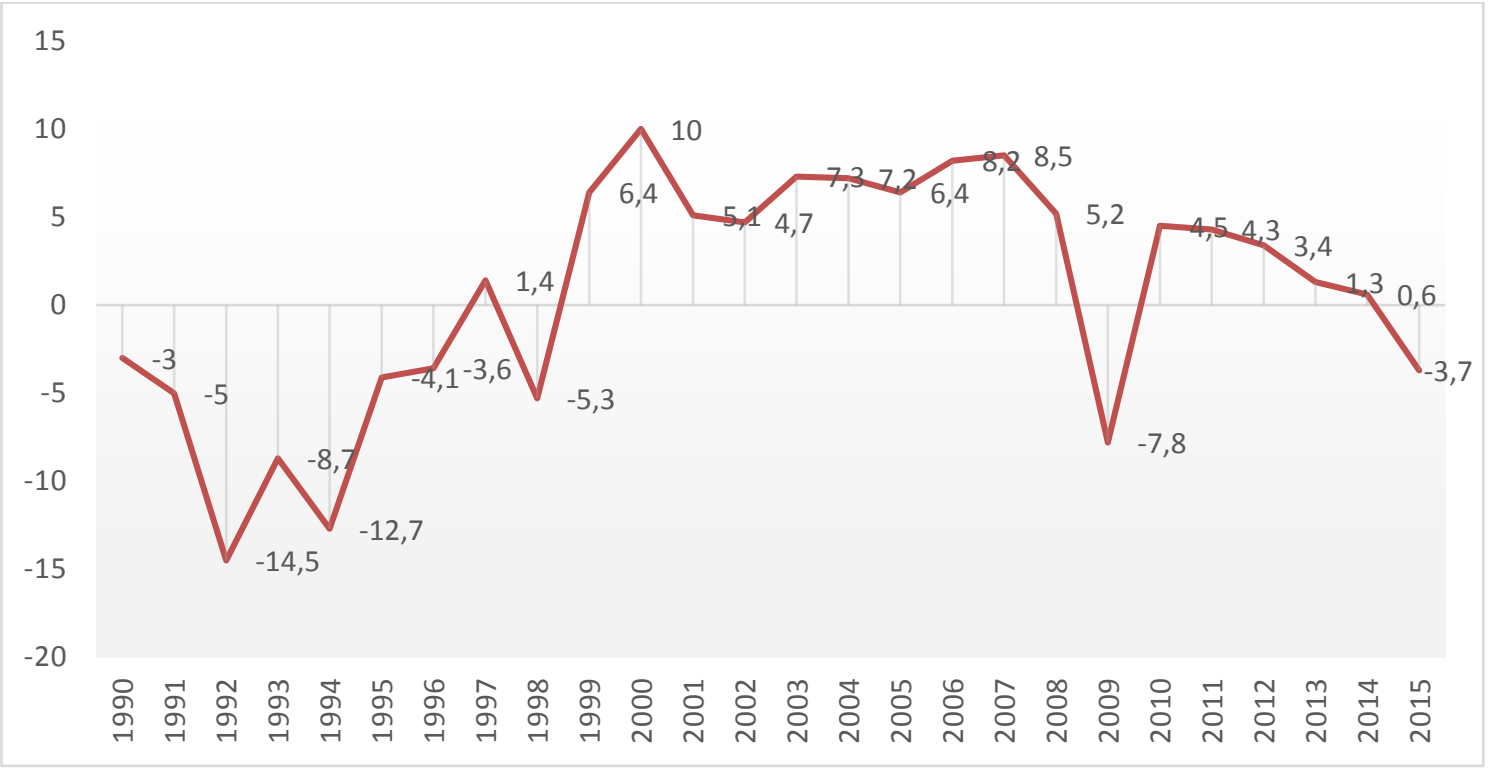

Elaboração Própria/Fonte: Banco Mundial

Para autores como Stiglitz (2003), esta crise esteve diretamente relacionada ao modo apressado e desregulado como o país abandonou sua economia planificada em direção a uma economia de mercado, o que ficou conhecido como "terapia de choque", política liderada Yegor Gaidar (primeiro-ministro) e Anatoli Chubais (ministro responsável pelo processo de privatizações), com o auxílio de economistas ocidentais, do FMI e da Secretaria do Tesouro dos Estados Unidos. Tal política prescrevia ações como 
liberalização dos preços, abertura de mercado, ajuste fiscal e privatização das empresas estatais. O objetivo final era uma transição rápida para o modo de produção capitalista. Tal política, porém, não obteve o resultado esperado. Entre as principais falhas, não se considerou que o novo Estado russo ainda não possuía os fundamentos mínimos necessários para tais medidas ${ }^{40}$.

O crescimento econômico foi também afetado por sucessivas crises políticas. Entre setembro e outubro de 1993, menos de dois anos após a dissolução da União Soviética, Yeltsin enfrentou o parlamento russo, que buscava retirá-lo da presidência em um processo de impeachment. Após um longo impasse, os parlamentares se entrincheiraram no prédio do parlamento (conhecido como Casa Branca), Yeltsin, em resposta, mandou o Exército bombardear o prédio e prender seus opositores ${ }^{41}$. Depois, substituiu a antiga constituição soviética, em vigor desde 1977, por uma nova carta, a qual foi referendada pela população russa em novembro de 1993. De acordo com o novo texto, a Duma, até então a única câmara parlamentar (Soviete Supremo), foi transformada em uma câmara baixa ${ }^{42}$. Conforme observa Segrillo (2012, p. 106), “a nova Constituição foi vista como sendo fortemente presidencialista (ao contrário da soviética, que era teoricamente 'parlamentarista', ao colocar os sovietes como órgãos legislativos supremos)".

Outra fonte de instabilidade política foi o conflito na Chechênia. Após o fim da União Soviética, essa província se declarou independente da Rússia, mas não obteve reconhecimento de Moscou. Em 1994, sobreveio o primeiro conflito militar e as forças armadas russas não conseguiram retomar o controle da república separatista, retirando suas tropas da região em 1996 após um armistício. A Rússia só retomaria o controle total sobre a Chechênia em 1999.

No âmbito da "terapia de choque", o processo de privatização das antigas empresas estatais soviéticas se mostrou bastante controverso, gerando impactos econômicos e políticos. Em junho de 1992, um decreto presidencial estabeleceu quais seriam as diretrizes adotadas para a venda desses ativos públicos. Na primeira fase do processo, de 1992 a 1994, ex-funcionários de empresas estatais receberiam o direito de

\footnotetext{
${ }^{40}$ A "terapia de choque" também foi aplicada na Polônia, onde se avalia que tenha sido relativamente mais bem-sucedida que na Rússia (APPLEYARD; FIELD JR.; COBB, 2010).

${ }^{41}$ Os políticos opositores foram anistiados no ano seguinte.

${ }^{42}$ A nova Carta determinou ainda que os membros da Duma seriam eleitos por sufrágio universal e voto distrital misto. A nova constituição criou também uma câmara alta, o Conselho da Federação. Seus membros seriam compostos por dois representantes de cada uma das unidades constituintes da Federação russa (um indicado pelo Poder Executivo local e outro pelo Poder Legislativo local) (SEGRILLO, 2012).
} 
participação em suas antigas empresas por meio da distribuição de vouchers. No entanto, a possibilidade de revenda desses vouchers acabou por gerar uma concentração de ações nas mãos de poucas pessoas ${ }^{43}$, principalmente nas dos antigos dirigentes das estatais, $o$ que tornou essa fase do processo conhecida como a "privatização da nomenclatura". Os novos acionistas majoritários dessas empresas ficaram conhecidas como "diretores vermelhos" devido ao histórico como dirigentes durante o período socialista (ALVES, 2011; SCHUTTE, 2011).

A segunda fase do processo de privatização teve início em 1995, com o lançamento do programa conhecido como "empréstimos por ações", instituído por decreto presidencial. Por meio desse programa, o governo oferecia participação nas antigas estatais russas em troca de empréstimos, uma vez que enfrentava enormes dificuldades financeiras. O programa foi idealizado pelo então vice primeiro-ministro Vladimir Potanin, que propôs a entrega das ações das estatais como garantia de empréstimos ao Estado russo. O plano previa que o governo pagaria os empréstimos e retomaria as ações. No entanto, tais empréstimos nunca foram pagos e os bancos puderam levar as ações a leilão, o que resultou na aquisição destas por alguns poucos grupos privados e pelos próprios bancos. ${ }^{44}$

Para Goldman (2008), os mentores do programa sabiam, desde o início, que a probabilidade de o governo pagar os empréstimos era muito pequena, de modo que o esquema "empréstimos por ações" foi pensado justamente para repassar os ativos das empresas estatais a alguns seletos grupos privados. O esquema teria sido a forma encontrada para contornar as restrições legais concernentes à privatização da indústria de petróleo (TREISMAN, 2010). Os leilões de venda excluíram diversos interessados sob a alegação de problemas burocráticos em suas inscrições.

No setor de petróleo, o Ministério de Combustíveis e Energia tornara-se uma sociedade anônima ainda em 1991, a Rosneftgaz. A privatização ocorreu por meio do desmembramento dessa sociedade em empresas verticalmente integradas. Daí surgiram a Rosneft (que permaneceu sob o controle do Estado), além de Lukoil, Yukos,

\footnotetext{
${ }^{43}$ A maior parte da população não sabia como manejar as ações às quais os vouchers dariam direito e optou por trocá-los por produtos de consumo imediato.

${ }^{44}$ A partir de 1988, após a Perestroika (reconstrução econômica), o governo Gorbachev passou a permitir a criação de pequenas cooperativas privadas ("A lei das cooperativas"). Essa mesma lei permitia a criação de bancos, os quais poderiam ser fundados com um volume de capital muito baixo. Entre 1989 e 1994, o número de bancos privados passaram de cinco para 2.500 (SAKWA, 2014). Posteriormente, o lucro dos bancos que seguiram operando aumentou exponencialmente devido à inflação e à desregulamentação do mercado financeiro russo em 1990.
} 
Surgutneftegaz, Sidanco e Sibneft (todas leiloada por meio do esquema "empréstimos por ações"). Fora do setor de petróleo, também foram privatizadas, por meio desse esquema, as mineradoras Norilsk, Mechel e Novolipetsk (SAKWA, 2014; TREISMAN, 2010).

O setor de gás, no entanto, não passou por esse mesmo processo de privatização. Um dos principais responsáveis foi o então Ministro da Indústria do Gás da União Soviética, Viktor Chernomyrdin, que evitou que a indústria fosse desmembrada como ocorrera no setor de petróleo. Em agosto de 1989, Chernomyrdin tomou a iniciativa de transformar o Ministério da Indústria do Gás - criado em 1965 - em uma sociedade anônima: a Gazprom, totalmente controlada pelo Estado ${ }^{45}$.

Em dezembro de 1992, Gaidar teve de deixar o cargo de primeiro-ministro em razão da forte oposição à sua política monetária contracionista, e Chernomyrdin assumiu o posto, tendo sido substituído na Gazprom por Rem Vyakhirev. As gestões de Chernomyrdin e Vyakhirev foram marcadas por inúmeras acusações de corrupção, tendo ambos adquirido uma parcela significativa de ações da empresa quando elas passaram a ser negociadas (GOLDMAN, 2008; BAEV, 2008; YERGIN, 2012).

A partir de 1993, a Gazprom passou a distribuir vouchers. Em 1994, estabeleceuse que $40 \%$ de suas ações deveriam permanecer sob o controle do Estado por pelo menos três anos, $15 \%$ deveriam ser destinadas aos funcionários da empresa e 9\% poderiam ser vendidas a investidores estrangeiros. No final da década, quase $62 \%$ de suas ações já pertenciam a grupos privados (GOLDMAN, 2008; VICTOR; SAFYER, 2011; PANIBRATOV, 2012; GAZPROM, 2016).

Gustafson (2012) observa que, embora o gás já desempenhasse um papel crucial na economia soviética em sua última década, ele se tornou absolutamente indispensável para a Rússia após o desmembramento da URSS. Em 1990, essa fonte representava 43\% do consumo total de energia primária no país. Em 2000, a proporção subiu para $52 \%$. Para esse autor, um dos fatos notáveis da era pós-soviética é que a Rússia se tornou, em grande medida, uma economia movida a gás, com a Gazprom consolidando-se como a mais rica e poderosa corporação russa.

O processo de privatização das demais estatais soviéticas é ainda bastante impopular na Rússia, porquanto, em vez de ajudar no estabelecimento de uma economia de livre concorrência, com mais opções e menores preços à população, conforme

\footnotetext{
${ }^{45} \mathrm{Em} 1987$ foi promulgada a "Lei sobre as empresas socialistas", conferindo maior autonomia às empresas soviéticas. Seus diretores passaram a ter maior comando sobre as finanças e orçamento das empresas e foram encorajados a maximizar os lucros (GUSTAFSON, 2012).
} 
preconizavam Gaidar e Chubais, as antigas estatais foram substituídas por monopólios privados.

Concluído o processo, aqueles que emergiram como os principais acionistas das antigas estatais ficaram conhecidos como "oligarcas": um grupo de homens de negócio que prosperaram enormemente. De acordo com Segrillo (2012), os “oligarcas" mantiveram considerável influência política sobre o governo de Yeltsin, em uma relação caracterizada pela troca de favores: enquanto eles receberam vantagens durante o processo de privatização, Yeltsin obteve seu apoio político e midiático em sua campanha de reeleição em 1996, quando sua popularidade era extremamente baixa. No segundo turno, Yeltsin, com o apoio maciço dos conglomerados de comunicação recentemente privatizados, derrotou o candidato do Partido Comunista, Guennady Zyuganov, com $53,8 \%$ dos votos.

Markov (2007) destaca que a segunda votação decorreu em ambiente de flagrante fraude eleitoral, com autoridades ameaçando anular os resultados das eleições em caso de vitória do partido comunista. Nesse cenário, a influência dos "oligarcas" dentro da administração de Yeltsin era evidente. Os mais proeminentes entre eles ficaram conhecidos como os "Sete Banqueiros", uma referência ao "Reinado dos Sete Boiardos", grupo de nobres russos do início do século XVII que detinha o poder de fato na Rússia ${ }^{46}$ (PEREIRA, 2015; DUTKIEVWICZ, 2011).

Em 1997, após sucessivos anos de crise política e crescimento negativo, o Produto russo finalmente apresentou uma pequena melhora (ver Figura 6), embora mais da metade das rendas fiscais fossem destinados ao pagamento de dívidas. Entretanto, a crise asiática de 1997, que se espalhou rapidamente pelas ex-repúblicas soviéticas e América Latina, mergulhou a Rússia em uma nova crise econômica. Houve fuga massiva de capitais dos chamados "mercados emergentes", fazendo com que as reservas internacionais russas

\footnotetext{
${ }^{46}$ O grupo dos "Sete Banqueiros" era formado por: Boris Berezovski (então acionista da petroleira Sibneft e dono do canal TV1, antiga Televisão Pública Russa), Mikhail Khodorkovsky (que controlava o banco Menatep e a petroleira Yukos), Vladimir Gusinsky (fundador do banco Most e do conglomerado de comunicação Media Most, dona do canal NTV), Vladimir Potanin (idealizador do programa "ações por empréstimos", controlador do banco Onexim, que adquiriu o controle da mineradora Norilsk), Alexander Smolenski (dono do banco Stolichny), Pyotr Aven (sócio do grupo Alfa) e Mikhail Fridman (também acionista do grupo Alfa). Além desses setes, eventualmente eram adicionados ao grupo Vladimir Vinogradov (dono do Inkombank) e Vitali Malkin (proprietário do Rossiysky Kredit). Muitos desses empresários também ocuparam cargos na administração de Yeltsin, Berezovski, por exemplo, foi ViceSecretário do Conselho de Segurança; Potanin, Vice Primeiro-Ministro; Khodorkovsky, Vice-Ministro de Combustíveis e Energia. Berezovski e Gusinsky também foram eleitos deputados nas eleições legislativas de dezembro de 1999.
} 
atingissem seu valor mínimo, obrigando o governo a suspender os pagamentos da dívida pública. O PIB diminuiu 6\% em 1998, os rendimentos reais da população decresceram cerca de 33\% (STARODUBROVSKAIA, 2005).

Ressalte-se que 1997 também marca um período de mudanças bruscas para o mercado de hidrocarbonetos. Nesse mês, a Arábia Saudita, em uma reunião em Jacarta, decidiu autorizar um aumento de $10 \%$ no teto de produção da Opep. O resultado, porém, foi o oposto do esperado: havia excesso de petróleo no mercado mundial (o Iraque voltara ao mercado sob o programa "Petróleo por Comida" da ONU). A junção de altos estoques com a crise financeira na Ásia resultou na queda no preço, repercutindo fortemente na economia russa, bastante dependente da renda gerada pela venda desses recursos.

Em março de 1999, os países da Opep voltaram a se reunir e concordaram em diminuir a produção. Noruega, México e Rússia aderiram ao acordo. Com a recuperação das economias asiáticas, os preços mais uma vez iniciaram um movimento ascendente a partir do final de 1999. Os anos de bonança econômica, contudo, seriam aproveitados por Vladimir Putin.

Em março de 1998, Yeltsin substituiu o primeiro-ministro Viktor Chernomyrdin por Serguei Kirienko. Cinco meses depois, este também foi demitido, mas a Duma não aceitou a indicação da volta de Chernomyrdin. O cargo ficaria vago até setembro daquele ano, quando Yevgeny Primakov, então ministro das Relações Exteriores, tornou-se primeiro-ministro. A experiência não chegaria a durar nove meses. Em maio de 1999, Primakov foi substituído por Serguei Stepashin sob a alegação de demora na realização das reformas necessárias. Stepashin, por sua vez, foi demitido três meses depois, em agosto de 1999, dando lugar a Vladimir Putin (REIS FILHO, 2007). Em meio a inúmeros escândalos de corrupção envolvendo os "oligarcas" e Yeltsin, este renunciou à presidência da Rússia em 1999. Putin, então primeiro-ministro, assumiu interinamente a presidência.

\subsection{Putin e a Reestatização}

A década de 2000, na Rússia, marca o início da "era Putin”. Em 16 de agosto de 1999, Vladimir Putin foi designado primeiro-ministro após Yeltsin ter demitido todo seu gabinete em virtude da crise econômica que o país atravessava após a crise asiática de 1998. Em pouco mais de 17 meses, Putin, então uma figura relativamente desconhecida 
no meio político russo ${ }^{47}$, foi o quinto primeiro-ministro, tendo permanecido no cargo até 31 de dezembro de 1999, quando Yeltsin inesperadamente renunciou à presidência em meio a escândalos de corrupção ${ }^{48}$.

Antes de ser eleito presidente, Putin chefiou a operação que derrotou os guerrilheiros separatistas da Chechênia ${ }^{49}$, o que lhe conferiu grande popularidade. A vitória contra a república rebelde e a melhora na economia russa ${ }^{50}$ ajudaram a eleger Putin presidente nas eleições de março de 2000, com 52\% dos votos, ainda no primeiro turno. Em março de 2004, Putin foi reeleito presidente com $71 \%$ dos votos, também no primeiro turno. Em 2008, Putin foi sucedido por seu aliado político, Dimitri Medvedev, que o indicou como primeiro-ministro. Em 2012, Putin foi novamente eleito presidente, devendo permanecer no cargo até 2018.

Verifica-se que, durante o período em que esteve à frente do poder na Rússia, Putin trouxe estabilidade ao conturbado cenário político e econômico do país. Já no início da década de 2000, os preços do petróleo e do gás retomaram uma trajetória de alta no mercado internacional, o que permitiu ao novo presidente empreender ações que retomassem o crescimento econômico. De 2000 a 2008, a taxa de crescimento do país

\footnotetext{
${ }^{47}$ Vladimir Vladimirovitch Putin é ex-funcionário do serviço secreto russo, a antiga KGB, que depois se tornou o Serviço Federal de Segurança (Federalnaya Sluzhba Bezopasnosti - FSB). Após deixar essa organização em 1991, Putin dirigiu o Comitê de Relações Internacionais da prefeitura de São Petersburgo durante o mandato de Anatoli Sobchak e também ocupou a subprefeitura. Após a derrota de Sobchak nas eleições de 1996, Putin foi convidado a integrar o gabinete de Yeltsin, quando, entre outros cargos, ocupou a diretoria do Serviço Federal de Segurança de 1998 a 1999.

${ }^{48}$ Segundo Adam (2011), a renúncia de Yeltsin foi resultado de um acordo entre a chamada "Família" (grupo do qual faziam parte a família de Yeltsin e alguns "oligarcas") com Putin. Os arquitetos da renúncia queriam assegurar que seu sucessor não se desviaria do curso seguido até então, dando continuidade às políticas que resultaram no fabuloso enriquecimento e influência política do círculo próximo a Yeltsin. Uma vez que a constituição russa de 1993 estabelecia que diante da renúncia do presidente, o primeiroministro assumiria as funções executivas pelo período de três meses, Putin, como primeiro-ministro, poderia, até a data das eleições (marcadas para março de 2000), fazer uso da máquina estatal para promover sua candidatura à presidência. Em troca, deveria impedir o prosseguimento das investigações, já em curso, sobre as acusações de corrupção contra Yeltsin e alguns de seus familiares e aliados políticos. Ao assumir interinamente a presidência, em janeiro de 2000, Putin concedeu imunidade jurídica a Yeltsin e a sua família por meio de um decreto.

${ }^{49}$ Dois eventos fizeram Moscou reiniciar a ação armada na região da Chechênia em 1999: o primeiro foi a invasão da região vizinha do Daguestão (também pertencente à Federação Russa) por rebeldes chechenos; o segundo foi a explosão de prédios residências em Moscou por terroristas supostamente chechenos (há acusações de que as explosões foram, na verdade, planejadas pelo próprio Serviço Secreto Federal com o intuito de justificar uma nova ação armada contra a Chechênia). Nesta segunda intervenção, a Rússia saiu vitoriosa, expulsando os rebeldes chechenos do Daguestão e impedindo a independência da própria Chechênia. É preciso destacar, também, que a Chechênia está localizada em uma região estratégica, no Cáucaso, abrigando reservas e petróleo e gás e sendo um trajeto importante corredor para o transporte de petróleo russo para a Europa.

${ }^{50}$ Após ter enfrentado um encolhimento de 5,4\% em seu Produto em 1998, a economia russa cresceu 6,4\%. Durante os dois mandatos de Yeltsin, apenas nos anos de 1997 e 1999 o Produto foi positivo.
} 
ficou em torno de $7 \%$ ao ano, período que coincidiu com a alta internacional dos preços de petróleo e gás, após cerca de quinze anos de preços baixos.

Em 2004, o governo russo criou um fundo de estabilização com o objetivo de mitigar os efeitos da elevação do preço dos hidrocarbonetos sobre a taxa de câmbio, evitando a sobrevalorização do rublo e poupando recursos para períodos de preços baixos $^{51}$ (MEDEIROS, 2011; SCHUTTE, 2011). Em 2006, o país pagou todas as dívidas que haviam sido contraídas junto ao Fundo Monetário Internacional (FMI) e o Clube de Paris (grupo informal de grandes países credores). A maioria delas antes da data de vencimento (DONALDSON; NOGEE, 2005). Ao final dos dois primeiros mandatos de Putin, a Rússia havia acumulado mais de 476 bilhões de dólares em reservas internacionais, valor menor apenas que as reservas de Japão e China (MANKOFF, 2011).

Putin pôde, portanto, reivindicar os créditos por ter restaurado a estabilidade na Rússia após a caótica transição econômica para o livre mercado. Um aspecto que com frequência é destacado como símbolo da mudança imprimida por sua administração refere-se à maior presença do Estado na economia. De fato, devido ao maior crescimento econômico, a administração de Putin, em seus dois primeiros mandatos como presidente, aumentou o número de funcionários estatais e triplicou os gastos militares (RUTLAND, 2008). No entanto, o traço mais marcante do fortalecimento do Estado seria a reestatização de empresas que haviam sido privatizadas no governo de Yeltsin. Nesse cenário, a Gazprom desempenhou papel de destaque.

Internamente, a empresa experimentou mudanças importantes. Em maio de 2001, Putin conseguiu o afastamento de seu chefe executivo, Rem Vyakhirev, envolvido em denúncias de corrupção (Chernomyrdin já havia sido afastado do conselho em 2000). Vyakhirev foi substituído por Alexei Miller. De acordo com Baev (2008), Putin sabia que jamais teria autoridade real sobre o país se não assumisse o controle de fato da empresa que respondia por cerca de $7 \%$ do PIB russo.

Em relação aos “oligarcas”, Segrillo (2012) observa que teria havido um acordo tácito entre eles e Putin. Com base nas novas regras de convivência, eles poderiam seguir com seus negócios desde que não interferissem na política. Aqueles que ousassem se envolver em atividades contrárias aos interesses da administração de Putin seriam despojados de seu capital econômico, como de fato ocorreu com Boris Berezovsky, Vladimir Gusinsky e Mikhail Khodorkovsky, os quais teriam ajudado grupos

\footnotetext{
${ }^{51}$ Em 2008, tal fundo foi desmembrado em um fundo de reservas e em um fundo de bem-estar.
} 
oposicionistas e financiados campanhas de difamação contra diversos membros do Kremlin.

Berezovski deixou a Rússia em 2001 sob a acusação de fraude fiscal, lavagem de dinheiro e assassinato, exilando-se em Londres. Seu exílio gerou inúmeras tensões diplomáticas entre a Rússia e Reino Unido, uma vez que o governo britânico se recusou a deportá-lo. Além disso, o episódio envolvendo o envenenamento por polônio do exfuncionário da $\mathrm{KGB}$, Alexander Litvinenko ${ }^{52}$, aumentou ainda mais a tensão entre os dois países. Os casos de Berezovisky e Litvinenko estão interligados porque Litvinenko dissera em entrevista que o governo russo pretendia matar Berezovsky ${ }^{53}$.

Quanto a Gusinsky, apenas três meses após as eleições presidenciais, a Gazprom assumiu o controle de seu canal de televisão, NTV, parte do grupo Media Most, que foi desmantelado sob acusações de fraudes fiscais. Gusinsky foi preso em junho daquele ano sob acusações de lavagem de dinheiro, mas solto três dias depois, quando permitiu que a gigante do gás assumisse o controle da NTV - a Gazprom era a principal credora do grupo. $^{54}$

Não obstante, o exemplo mais emblemático da "perseguição" aos oligarcas por meio da utilização da máquina estatal - especialmente da Gazprom - foi o caso da Yukos e a prisão de seu acionista majoritário, Mikhail Khodorkovsky. Em outubro de 2003, Khodorkovsky, então considerado o homem mais rico da Rússia, foi preso sob a acusação de evasão fiscal e fraude ${ }^{55}$. Em dezembro de 2004, a fim de pagar a dívida fiscal da empresa, a Yukos foi forçada a vender Yugansneftegaz, seu principal braço na produção de petróleo. A Yugansneftegaz foi adquirida em um leilão por um grupo econômico até então desconhecido, o Baikal, que mais tarde foi adquirido pela petroleira estatal Rosneft (STERN, 2005). Na época, o governo russo analisava a possibilidade de fundir a Rosneft e a Gazprom, criando uma gigante do petróleo e do gás. Porém, conforme observa Schutte (2011, p. 104), “o Kremlin teria optado por mantê-las separadas, inclusive porque seriam controladas por grupos diferentes do núcleo duro do governo Putin”

\footnotetext{
${ }^{52}$ Litvinenko deixou a Rússia em 2000 e solicitou asilo político ao Reino Unido. Moscou, por sua vez, tem se recusado a extraditar um dos supostos assassinos de Litvinenko, Andrei Lugovoi.

${ }^{53}$ Interessante destacar que Berenzosky foi réu em uma ação da Justiça brasileira e chegou a ter sua prisão decretada em 2007 sob a acusação de lavagem de dinheiro nas operações envolvendo o Corinthians e a Media Sports Investment (MSI), empresa com sede em Londres e representada no Brasil por Kia Joorabchian. Em março de 2013, Berezovsky foi encontrado morto em sua casa em Londres, tudo indica que ele tenha se enforcado.

${ }^{54}$ Gusinsky exilou-se inicialmente na Espanha, depois se mudou para Israel, onde também esteve envolvido em casos de corrupção.

${ }^{55}$ Em 2010, uma nova sentença condenou Khodorkovski e seu sócio Platon Lebedev por roubo de petróleo e lavagem de dinheiro. Khodorkovski saiu da prisão em 2013 após ter recebido perdão de Putin.
} 
Goldman (2008) e Orttung (2009) apontam para o fato de Khodorkovsky estar negociando participações em seus negócios com investidores estrangeiros como a principal razão para a intervenção do Kremlin na Yukos. Três semanas antes de sua prisão, Khodorkovsky teria assinado um memorando de intenções com a ExxonMobil. Além disso, planejava a construção de um oleoduto até a China, o qual concorreria com o monopólio estatal da Transneft.

Em junho de 2005, o governo russo conseguiu aumentar sua participação na Gazprom através da Rosneft, a petroleira estatal comprou 10,74\% das ações da Gazprom, proporcionando ao Estado russo 50,002\% delas, garantindo o controle governamental da gigante do gás. Assim, após ter sido parcialmente privatizada na década de 1990, a empresa voltava ao controle majoritário do Estado (GOLDMAN, 2008; SCHUTTE, 2011; PANIBRATOV, 2012).

No mesmo ano, mais um episódio de compra de ativos privados pela Gazprom ganharia destaque. Em setembro, a gigante do gás adquiriu o controle da Sibneft - então a quinta maior produtora de petróleo da Rússia -, elevando assim sua participação na indústria de petróleo, de menos de 15\% em 2004 para mais de 30\% um ano depois (POPOV, 2007). Segundo Goldman (2008), a venda da Sibneft - então pertencente Roman Abramovich ${ }^{56}$ - coadunava-se com os esforços do Kremlin de evitar que empresas multinacionais controlassem recursos energéticos russos. Abramovich, assim como Khodorkovsky, teria planejado vender a Sibneft para empresas estrangeiras (havia ofertas da Chevron-Texaco, Shell e Total), mas teria mudado de ideia por pressões do governo.

Em julho de 2006, uma nova legislação estabeleceu que todas as exportações de gás natural, GNL e gás liquefeito de petróleo deveriam estar sob o monopólio da Gazprom, ainda que a empresa já tivesse um monopólio de fato na exportação de gás (BELYI, 2011). Em janeiro de 2007, um tribunal de arbitragem russo retirou um regulamento antimonopólio que proibia a Gazprom de comprar ações dos demais produtores de gás na Rússia (STENGEN, 2011), abrindo o caminho para o monopólio da Gazprom também na produção de gás.

No final de 2006, a Gazprom se tornou a principal acionista do projeto Sakhalin2 - um empreendimento para a exploração de GNL na ilha Sakhalin, no extremo leste da

\footnotetext{
${ }^{56}$ Segundo Orttung (2009), Abramovich, diferentemente de Khodorkovski, possuía boas relações com o Kremlin, de modo que ele teria sido muito bem recompensado pelas vendas dos ativos da Sibneft. Em 2011, Boris Berezovsky, antigo sócio da Abramovich na Sibneft, moveu uma ação contra o ex-parceiro comercial na Justiça britânica alegando ter sido intimidado a vender sua parte na petroleira. A ação, no entanto, foi julgada improcedente.
} 
Rússia - após o consórcio Sakhalin Energy, formado por Shell, Mitsui e Mitsubishi, ter recebido multas severas em razão de alegadas violações ambientais na Mar de Okhotsk. Posteriormente, o consórcio concordou em vender mais de metade das suas ações para a Gazprom, possibilitando a empresa entrar no mercado de GNL, no qual não tinha participação até então. O fato de Sakhalin-2 ser, até então, o único grande projeto de exploração de gás na Rússia que não tinha a participação de uma empresa russa é apontado como a principal razão para as rigorosas penalidades recebidas pelo consórcio liderado pela Shell (YERGIN, 2012; GOLDMAN, 2008).

Em junho de 2007, a Gazprom também se tornou o maior acionista na exploração do gigante campo de gás de Kovykta, no leste da Sibéria. A BP-TNK - uma joint venture criada em 2003 entre a BP e a russa TNK - concordou em vender sua participação para a Gazprom após descumprir as quotas de produção estipuladas pelas autoridades russas. A BP-TNK alegava inviabilidade do projeto devido à falta de demanda local significativa ou de um gasoduto de exportação para a China - o transporte de gás do campo de Kovykta para mercados consumidores devia ser feito exclusivamente pela Gazprom, que detém o monopólio de exportação de gás -, bem como a recusa das autoridades russas de rever as quotas de produção acordadas (ORTTUNG; TISSOT, 2010).

Destaque-se que o fim da União Soviética derivou na perda de ativos para a Gazprom, devido ao surgimento de países soberanos que reivindicaram para si o controle sobre a capacidade instalada pela empresa em seus territórios. Entretanto, logo esses países passaram a enfrentar dificuldades para pagar as contas do gás importado da Rússia, possibilitando à Gazprom oferecer o cancelamento de dívidas ou preços mais baixos no fornecimento em troca de participação acionária nas empresas de energia locais, obtendo, assim, presença significativa no setor de energia desses países (GOLDMAN, 2008).

Ao longo da década de 2000, a empresa aumentou sua participação - tendo, muitas vezes, assumido o controle acionário - em diversas empresas de energia que operam em países vizinhos. Em 2007, por exemplo, a estatal russa passou a controlar $63 \%$ da principal companhia de gás da Moldávia; em 2011, 50\% das ações da Beltransgaz, empresa que controla o ramal do gasoduto Yamal-Europa, que atravessa o território de Belarus (ver Figura 4), também passou ao controle da Gazprom após desentendimentos sobre o preço do gás envolvendo os dois países (ROCCO, 2015; GROMADZKI; KONONCZUK, 2007).

Em abril de 2008, pouco antes de deixar a presidência, Putin sancionou lei sobre investimento estrangeiro em setores estratégicos da economia russa ("Lei de Investimento 
Estrangeiro"), a qual estaria relacionada a preocupações de segurança nacional. A nova lei previu a necessidade de autorização do governo para os casos em que os investidores estrangeiros buscassem adquirir o controle acionário sobre mais de 50\% de uma empresa russa que atuasse em setores considerados estratégicos. Evidentemente, as indústrias de petróleo e gás foram incluídas na nova lei, juntamente com mais 42 setores (SCHUTTE, 2011).

Pomeranz (2010) observa que, embora tal prática não seja incomum (nos Estados Unidos, por exemplo, um departamento do Tesouro - The U.S. Department of Treasury's Committee on Foreign Investment in the United States (CFIUS) - revê regularmente o aumento da participação estrangeira em empresas americanas) ${ }^{57}$, a medida foi bastante criticada internacionalmente, reacendendo os questionamentos sobre uma suposta predisposição "estatista” de Putin.

Segundo autores como Goldman (2008) e Sakwa (2008), tal convicção políticoeconômica já estaria presente em Putin mesmo antes de ele assumir a presidência. Em sua tese de doutorado, submetida ao Instituto de Mineração de São Petersburgo em 1997, Putin defendeu a necessidade de controle estatal sobre os setores de recursos naturais e de energia. Em um artigo publicado dois anos depois, ele reiteraria esse ponto de vista, defendendo que para a Rússia superar seu atraso em relação às potências ocidentais, sua economia deveria crescer duas vezes mais que a economia desses países. A base para tal crescimento deveria advir da exploração de recursos minerais, sobretudo do petróleo e do gás e, para alcançar esse objetivo, o país precisaria criar corporações industriais e financeiras, verticalmente integradas, capazes de competir em igualdade de condições com empresas multinacionais. Em razão do legado soviético, Putin argumentava que seria impossível construir esse tipo de corporação na Rússia sem o forte apoio do Estado (PUTIN apud SAKWA, 2008, p. 41). Esse pensamento seria o embrião das "campeãs nacionais" surgidas durante seu período à frente da presidência.

Putin é por vezes descrito como um "siloviki”, expressão que designa indivíduos oriundos dos órgãos de segurança dentro do Estado russo. Esse grupo se destaca por assumir posturas nacionalistas na economia, defendendo um Estado forte. Segundo Alves

\footnotetext{
57 Tem-se um exemplo da interferência de governos (mesmo os chamados liberais) na área de energia no caso Unocal: em 2005, a chinesa CNOOC tentou adquirir a Corporação Unocal, com sede nos EUA, mas a transação foi bloqueada pelo Congresso americano com base no pressuposto de que a segurança nacional do país estaria ameaçada caso a empresa chinesa adquirisse uma parte ínfima dos suprimentos norteamericanos de petróleo (menos de $1 \%$ da produção total dos EUA). A Unocal acabou sendo vendida para a Chevron (YERGIN, 2012).
} 
(2011, p. 216), os siloviki defendem que "setores estratégicos não devem ser deixados sob o controle privado, quanto mais se for estrangeiro". Renz (2015) aponta para o fato de os siloviki terem ganhando maior proeminência política durante a administração de Putin. Em parte, devido ao fato de o presidente não estar afiliado a nenhuma agremiação política quando chegou ao poder, tendo recorrido a contatos pessoais - entre os quais estavam antigos colegas da KGB - para nomear pessoas para os postos chave da burocracia russa. Não obstante, a autora também observa que indivíduos identificados como "liberais" ou "tecnocratas" - a exemplo do ex-presidente Dimitri Medvedev e outros antigos colegas de Putin de São Petersburgo - igualmente ganharam espaço.

Goldman (2008) argumenta que Putin, assim como outros líderes russos que o antecederam, jamais deixou de acreditar na necessidade de o Estado reter o controle sobre os recursos naturais do país. A diferença principal entre as administrações nacionalistas e liberais no país seria simplesmente a necessidade de capital e o estágio do conhecimento tecnológico, sendo que, em alguns períodos, essa necessidade é mais premente que em outros. Assim, segundo este autor, em períodos de preços baixos no mercado internacional e de dificuldade econômica, os governos russos tendem a ser mais liberais em relação a investimentos estrangeiros, especialmente no que concerne às IOCs; no entanto, assim que os preços internacionais retomam uma trajetória altista, as portas se fecham para empresas estrangeiras e os recursos energéticos passam a ser usado para outros fins, até mesmo como uma ferramenta de política externa. O que teria mudado na década de 2000, segundo Goldman, é a ascensão de novos grandes consumidores de energia, como China e Índia, o que possibilitaria a Moscou maior poder de negociação com seu parceiro tradicional: a Europa. Desse modo, o aumento da demanda por energia na Ásia teria permitido ao Kremlin utilizar a Gazprom como uma "arma energética".

Mankoff (2011), assim como Goldman (2008), ressalta o incentivo a criação de “campeãs nacionais" no setor de energia, com o objetivo de aumentar a projeção de poder mundial da Rússia, sendo a Gazprom a mais importante delas. A partir de então, segundo Mankoff, o controle sobre recursos energéticos iria incrementar o poder que antes derivava somente da força militar, permitindo à elite governante russa retomar a confiança na possibilidade do país continuar a exercer um papel de destaque nas relações internacionais contemporâneas.

Tsygankov (2016), no entanto, defende que, embora o Estado russo tenha aumentado sua participação na produção e na infraestrutura de distribuição de recursos energéticos a partir de 2000, seu interesse principal seria garantir segurança e estabilidade 
na entrega desses suprimentos, além de promover uma maior integração ao mercado da Europa Ocidental. Desse modo, o aumento no preço do gás imposto pela Gazprom a algumas ex-repúblicas soviéticas, comumente rotuladas de retaliações políticas, seriam tentativas de restabelecer a relação com esses países com base nas leis de oferta e demanda, retirando os subsídios que existiam durante o período soviético, adequando-as a economia de mercado e as regras da Organização Mundial do Comércio (OMC).

Já Goldthau (2008) defende que a Rússia não tem tanta influência sobre o mercado energético conforme se imagina. A falta de modernização tecnológica da Gazprom e as leis internas russas - que impõem subsídios ao preço do gás vendido domesticamente teriam deixado à empresa em dificuldades econômicas e, portanto, sem margem de manobra para executar possíveis projetos geopolíticos do Kremlin. Nesse sentido, a compra de empresas privadas russas e de outros ativos nas antigas repúblicas soviéticas teria prejudicado ainda mais a capacidade de investimento da Gazprom, comprometendo o próprio fornecimento de gás. De acordo com perspectiva desse autor, em breve a Rússia terá que recorrer novamente a empresas estrangeiras para ter acesso a melhores processos de exploração, os quais serão fundamentais para a extração de petróleo e gás em áreas complexas, como no Ártico.

Em 7 de maio de 2008, Putin foi sucedido na presidência russa por Dimitri Medvedev. Após a eleição, Medvedev indicou Putin como primeiro-ministro. Mankoff (2011) destaca que Putin foi o principal responsável pela escolha de Medvedev como candidato e por sua eleição como presidente. O período em que Medvedev esteve à frente da presidência da Rússia é frequentemente abordado na literatura como "tandem" ou “diarquia" Medvedev-Putin, ressaltando a preponderância política de Putin sob o governo de Medvedev.

Antes da eleição, havia especulações sobre a possibilidade de se modificar a constituição para que Putin pudesse concorrer ao terceiro mandato consecutivo, iniciativa que teria grande probabilidade de obter êxito, uma vez que seu partido, o Rússia Unida, controlava mais de dois terços das cadeiras do Duma. No entanto, Putin optou por respeitar a constituição (WEGREN; HERSPRING, 2009). Após a eleição e Medvedev, ainda em 2008, a constituição de 1993 foi reformada, estendendo o mandato presidencial de quatro para seis anos nas eleições seguintes ${ }^{58}$.

\footnotetext{
${ }^{58}$ Os mandatos dos deputados da Duma também foram estendidos de quatro para cinco anos.
} 
Após a posse de Medvedev na presidência, os preços de petróleo (Brent) atingiram uma marca recorde: em julho, o preço chegou a 144 dólares o barril; no fim do ano. Entretanto, o preço caiu para abaixo de 50 dólares em razão da crise financeira de setembro de 2008, o que interrompeu quase uma década de contínuo crescimento da economia russa. Naquele ano, o Produto do país encolheu 7,8\% (ver Figuras 5 e 6). Assim como ocorrera em 1998, a economia sofrera com ataques especulativos, fuga de capitais e desvalorização cambial. Não obstante, em 2008 o país estava mais preparado: tinha resultados fiscais positivos e consideráveis reservas internacionais (ALVES, 2011).

A queda nos preços de energia e a consequente redução do crescimento econômico reacendeu o debate na Rússia sobre a dependência excessiva de seus recursos energéticos. Medvedev empreendeu iniciativas para tentar diversificar a economia e mitigar sua dependência de recursos minerais. Em seu governo foi lançado o projeto Skolkovo, um parque tecnológico concebido com a expectativa de emular a experiência do Vale do Silício, nos Estados Unidos (SKALAMERA, 2015). No entanto, conforme observam Shleifer e Treisman (2011), embora tanto Medvedev quanto Putin falassem bastante sobre a necessidade de a Rússia se modernizar economicamente, eles teriam consciência de que, pelo menos até a década seguinte, a prosperidade da Rússia dependeria de garantir mercados estáveis e preços relativamente altos para o petróleo e o gás exportado pelo país.

O fim do mandato de Medvedev, em 2012, e a volta de Putin à presidência ocorreu em um período de declínio econômico russo, o qual se acentuou em 2013, principalmente em razão da queda nos preços do petróleo e do gás no mercado internacional. Conforme observa Sakwa (2013), essa queda de preços representa o "calcanhar de Aquiles" para a estratégia russa de intensificar sua atuação internacional tendo como base a importância de suas reservas fósseis para a economia mundial. Nesse cenário, é interessante observar se haverá, de fato, uma retração na atuação internacional russa em um contexto de preços baixos. 


\section{Mercado do Gás e a Atuação Internacional da Gazprom}

Nesta seção analisaremos, com ênfase na atuação da Gazprom, o relacionamento da Rússia com quatro países: Alemanha, Ucrânia, China e Turquia. A escolha desses quatro casos se deve à percepção de que, em razão de suas diferenças econômicas, geopolíticas e geográficas, eles oferecem oportunidades para se avaliar o grau de eficácia da política externa energética russa em relação a diferentes países.

Nosso entendimento é o de que esse instrumento de política externa não acarreta os mesmos resultados em relação a todos os países. Em alguns casos, notadamente na Ucrânia, a chamada "arma energética" tem se mostrado ineficaz. Já em relação à Alemanha, a forte interdependência energética desse país com a Rússia tem permitido a Moscou se esquivar de sanções mais duras no contexto internacional, provando que o controle da Gazprom pelo governo russo tem trazido benefícios políticos ao país. A China e a Turquia representam casos intermediários. Embora a dependência energética dos recursos russos seja significativa também nesses países, outras variáveis conseguem reequilibrar a relação.

No caso da China, o relacionamento bilateral está fundamentado, por um lado, na necessidade que este país tem de ter acesso aos recursos naturais russos e, por outro, na premência de Moscou de explorar novos mercados e obter financiamentos. Esse alinhamento, contudo, não ocorre somente devido à interdependência energética. Pequim e Moscou compartilham concepções similares em relação a muitas questões internacionais contemporâneas, fato que será explorado com mais detalhamento no item 3.3 .

No caso da Turquia, a localização estratégica de seu território e sua política externa oscilante - ora buscando maior aproximação com as potências ocidentais, ora assumindo um posicionamento mais autonomista, ou mesmo próximo de Moscou - tem possibilitado a Ancara barganhar vantagens econômicos junto a Moscou. Destaque-se, contudo, que a política externa turca, apesar de rivalidades históricas, é bastante cuidadosa em não antagonizar a Rússia, conservando, assim, boas relações com seu mais importante parceiro comercial e principal fornecedor de energia.

A seguir são apresentados os argumentos que constituem o embasamento para a validade dessas asserções. 


\subsection{A Gazprom e a Alemanha}

Antes de iniciarmos a avaliação da atuação da Gazprom na Alemanha e verificarmos como ela repercute nas relações bilaterais entre Moscou e Berlim, analisaremos, primeiramente, os marcos legais que regulamentam o fornecimento e a distribuição de energia dentro da União Europeia, uma vez que a atuação da Alemanha, como membro da UE, precisa se desenvolver dentro desse quadro normativo. Ressaltese, também, que mesmo a atuação da Gazprom em países que não são membros plenos da UE, como Ucrânia e Turquia, é influenciada pelas regras do bloco europeu.

Entre os principais fornecedores de energia para a UE, a Rússia se destaca como o principal provedor externo do bloco. Aproximadamente um terço do gás consumido na Europa provém da Rússia. No entanto, em alguns países europeus, a dependência do gás russo é quase que completa, como se verifica na Áustria (98\%), Eslováquia (91\%), República Checa (89\%), Bulgária (83\%) e Hungria (80\%). Por outro lado, cerca de $70 \%$ do gás exportado pela Gazprom se destina ao bloco europeu (PICK, 2012; CARAFANO et al., 2015; KROPATCHEVA, 2015).

Embora a preocupação com a segurança energética tenha estado no centro da integração europeia - com a instituição da Comunidade Europeia do Carvão e do Aço pelo Tratado de Paris, de 1951, e com o estabelecimento da Euratom pelo Tratado de Roma, de 1957 - a UE não possui uma regra única para todos os países-membros no que concerne ao setor de energia, de modo que sua política energética comum é pouco eficiente. As normas sobre o setor estão enquadradas no princípio da subsidiariedade, com os Estados-membros mantendo, na maior parte das vezes, políticas independentes. Bros e Richard (2011) chamam atenção para as disparidades existentes dentro do bloco, tais como características geológicas e geográficas, tamanho da população, padrões de consumo, etc. Esses fatores dificultariam a consolidação de uma lógica comunitária que se sobreponha ao interesse individual de cada país no setor de energia. Embora o Tratado de Lisboa, em vigor desde 2009, tenha dedicado um capítulo exclusivo ao setor de energia e criado o Fórum Internacional de Energia, (International Energy Forum - IEF) os resultados ainda são modestos.

Em 1994, a Rússia e a Comunidade Econômica Europeia (CEE) assinaram um acordo de cooperação e parceria, o Partnership and Cooperation Agreement (PCA), que 
passou a vigora a partir de 1997 com um prazo de vigência de dez anos ${ }^{59}$. O PCA estabeleceu diretrizes liberais para o setor de energia, tendo como finalidade aumentar a integração comercial entre as partes. Em 2000, estabeleceu-se um "diálogo energético" no âmbito do PCA. Adicionalmente, Rússia e UE publicaram planos para o mercado de energia no qual ambos reconheceram seus interesses complementares e sua dependência mútua (CLOSSOM, 2009).

Paralelamente, em 1994, a CEE criou o Energy Charter Treaty $(E C T)^{60}$, tratado que entrou em vigor em 1998 e estabeleceu uma série de princípios em relação ao comércio, investimento e trânsito de recursos energéticos entre seus países-membros e também entre aqueles que comercializam com o bloco (entre os participantes estavam países da Europa Central e do Leste que ainda não faziam parte bloco europeu, além de Japão, Turquia, Austrália, Noruega e Rússia). Criou-se, ainda, um mecanismo de solução de controvérsias no âmbito do acordo.

Embora tenha assinado o ECT, a Rússia jamais o ratificou. Uma das principais razões seria a provisão que obriga todos os países a facilitar o trânsito de gás através de seus gasodutos, independentemente de origem, destino ou propriedade, a preços não discriminatório (Artigo 7) (AALTO; WESTPHAL, 2008; ECT, 1994). Essa disposição poderia, por exemplo, viabilizar o transporte de recursos de países da Ásia Central diretamente até a Europa utilizando a infraestrutura da Gazprom, sem que ela ficasse responsável pelo processo de comercialização, o que evidentemente não atenderia aos interesses da empresa. Em razão do controle da infraestrutura de gasodutos em toda a região das CEI, a Gazprom pode atualmente comprar gás na Ásia e revender na Europa.

Ressalte-se que o ECT não conseguiu acabar com os monopólios nacionais de energia dentro do próprio bloco europeu. A UE, porém, reclama o direito de reciprocidade em relação à Rússia, uma vez que companhias russas atuam no mercado europeu, ao passo que o transporte de gás russo ao exterior é monopólio da Gazprom e o transporte de petróleo é monopólio da Transneft (PEROVIC, 2009). Desde a década de 1990, a Gazprom tem buscado obter participação na infraestrutura de distribuição de energia em países da União Europeia, porém a resistência tem sido grande. As investidas da empresa no mercado europeu são apontadas como uma tentativa do Kremlin de utilizar sua “campeã nacional” com fins geopolíticos. A Gazprom, por sua vez, alega que a

\footnotetext{
${ }^{59}$ O PCA expirou em novembro de 2007. Negociações sobre um substituto estavam em andamento, mas foram paralisadas após a eclosão do conflito na Ucrânia.

${ }^{60}$ O ECT é decorrente da Carta Europeia da Energia de 1991.
} 
participação na distribuição final de energia no rico mercado da Europa Ocidental representa uma forma de agregar maior valor ao preço do gás ${ }^{61}$.

A necessidade de uma política energética conjunta tornou-se ainda mais premente após o alargamento da UE ocorrido em março de 2004, com a UE passando a incluir Estônia, Letônia, Lituânia, Polônia, República Checa, Eslováquia, Hungria, Eslovénia, Malta e Chipre ${ }^{62}$ (FINON; LOCATELLI, 2008). Quase a totalidade desses países depende do fornecimento da Rússia para o fornecimento de gás.

Em março de 2006, após controvérsia envolvendo o fornecimento de gás entre Rússia e Ucrânia, a UE lançou um Livro Verde (Green Paper) sobre segurança energética, no qual enfatiza que a dependência excessiva do bloco de poucos fornecedores, principalmente da Rússia, é prejudicial para sua segurança energética. Em seguida, o documento prevê uma série de recomendações, como a necessidade de diversificar fornecedores e o estabelecimento de novas rotas de transporte, as quais ligariam o território europeu aos recursos do Mar Cáspio, do Oriente Médio e do norte de África. O documento reconhece haver um desequilíbrio na infraestrutura existente para o fornecimento de energia e exorta a rápida ratificação do ECT pela Rússia (Comissão Europeia, 2006).

Em seguida, em setembro 2007, a UE lançou uma nova iniciativa baseada nos preceitos do Livro Verde, o Terceiro Pacote de Energia - Third Energy Package $(T E P)^{63}$, o qual apresenta como objetivos principais o desenvolvimento sustentável, econômico e social na distribuição de energia e a segurança no fornecimento. O TEP veda a uma única empresa controlar conjuntamente a produção, o transporte e a distribuição de energia dentro do bloco. O poder das reguladoras nacionais também foi reforçado a fim de evitar a monopolização do setor de energia (BROS; RICHARD, 2011).

Embora Bruxelas alegue que o TEP visa promover a concorrência dentro do bloco, mitigando também o poder de monopólio das grandes empresas de energia europeias, os termos do novo pacote afetam principalmente a Gazprom. O TEP - sob a argumento de

\footnotetext{
${ }^{61}$ Em 2006, ocorreu a fracassada tentativa da Gazprom de adquirir participação na empresa Centrica, maior distribuidora de gás natural no Reino Unido em 2006. "Quando se soube das intenções da empresa russa, o governo britânico demonstrou descontentamento e tomou medidas para dificultar a aquisição, chegando, inclusive, a considerar emendar a lei nacional sobre fusões e aquisições para bloquear a efetivação do negócio" (ALVES, 2011, p. 217-218).

62 Após o alargamento em direção aos países da Europa do Leste em 2004, a UE ainda incorporou Bulgária e Romênia em 2007, e Croácia em 2013. Todos eles fortemente dependente do gás russo para a geração de energia.

${ }^{63}$ O TEP foi aprovado em abril de 2009 pelo Parlamento Europeu nos termos do Livro Verde publicado pela Comissão Europeia em 8 março de 2006 (BROS; RICHARD, 2011)
} 
promover a segurança energética do bloco europeu - prevê condições claramente discriminatórias para empresas de países de fora do bloco, como a que impede que empresas estrangeiras controlem redes de transporte e de estocagem de energia em paísesmembros da UE, a não ser que haja um acordo específico sobre o tema entre este país e Bruxelas, o que ficou conhecido como "Cláusula Gazprom”. Conforme observa Youngs (2011), a “Cláusula Gazprom” acabou por demonstrar que a UE não pretendia aplicar em seu próprio mercado as regras de liberalização que pretendia impor à Rússia. Em contraposição as disposições do pacote, um ano após seu lançamento, os governos de Espanha e França atuaram ativamente para evitar que suas "campeãs nacionais" do setor de energia fossem compradas por empresas estrangeiras, ainda que de países-membros da UE. Em 2007, o então presidente Nicolas Sarkozy incentivou a fusão da Suez com a Gaz de France (GDF), impedindo a compra desta última pela italiana Enel. O governo espanhol, por sua vez, tentou impedir que a espanhola Endesa fosse comprada pela alemã Energy On (E.On.) Ruhrgas, favorecendo uma fusão com a também espanhola Gas Natural, que não se concretizou ${ }^{64}$ (MOTTA; RUTA, 2007; PIMENTEL, 2011; YOUNGS 2011).

Para Moscou, o TEP é incompatível com os princípios de não discriminação presentes nos acordos de parceria entre UE e Rússia e também com as regras da OMC. Não obstante as reclamações russas e as críticas ao pacote por parte de países importantes do bloco europeu, como Alemanha e França, o TEP entrou em vigor em 2011. No entanto, a fim de mitigar as divergências sobre essa nova política dentro do bloco, criou-se um sistema independente de operação (Independent System Operators - ISOs), que permitiu às grandes empresas de energia europeias manter o controle sobre a infraestrutura de transmissão, embora repassando as decisões de controle gerencial a um sistema de gestão independente (MANKOFF, 2009).

Em setembro de 2012, a Comissão Europeia iniciou uma investigação antitruste para examinar se a Gazprom estava impedindo o livre fluxo de gás na UE por meio do bloqueio de fornecedores rivais, da proibição de revenda do gás e da imposição de preços injustos $^{65}$ a oito países do leste europeu: Bulgária, Eslováquia, Estônia, Hungria, Letônia, Lituânia, Polônia e República Tcheca, países cuja matriz energética são extremamente

\footnotetext{
${ }^{64}$ Por fim, a E.on. desistiu de comprar a Endesa, que acabou sendo adquirida pelas italianas Enel e Acciona. ${ }^{65} \mathrm{O}$ problema estaria na prática da Gazprom de indexar o preço do gás ao do petróleo. Como recentemente tem havido mais oferta de gás do que de petróleo na Europa, o preço do gás estaria supervalorizado.
} 
dependentes do gás russo, variando de 75 a 100\% (KROPATCHEVA, 2015). A Comissão Europeia e a Rússia ainda negociam um possível acordo sobre a questão.

Muitos analistas apontam que a estratégia russa em relação ao mercado europeu é a de "dividir para conquistar" (HELÉN, 2015; PICK, 2012; BARYSCH, 2004), ou seja, estabelecer negócios específicos com os diferentes membros do bloco, garantindo vantagens a alguns e alimentando desavenças entre eles, com o intuito de não permitir a consolidação de uma política energética comum no âmbito da União Europeia. Nesse sentido, países importantes, como a Itália e, em maior medida, a Alemanha, impediriam um maior avanço em direção à institucionalização de uma política energética comum em razão de seu relacionamento privilegiado com Moscou.

No que tange à Alemanha especificamente, a parceria comercial entre Berlim e Moscou é de fundamental importância para ambos os países. A Rússia constitui um importante mercado para as exportações alemãs, o que responde pela geração de um total estimado de duzentos mil empregos. O mercado russo é também bastante atrativo para o capital alemão, que nele opera com cerca de seis mil empresas. Em contrapartida, mais de $35 \%$ do gás e cerca de $40 \%$ do petróleo consumidos na Alemanha provêm da Rússia (CRUZ, 2013). A Alemanha é o principal mercado consumidor do gás natural russo. 


\section{Turquia) \\ Figura 7 - Gráfico dos Principais Clientes da Gazprom na Europa (incluindo}

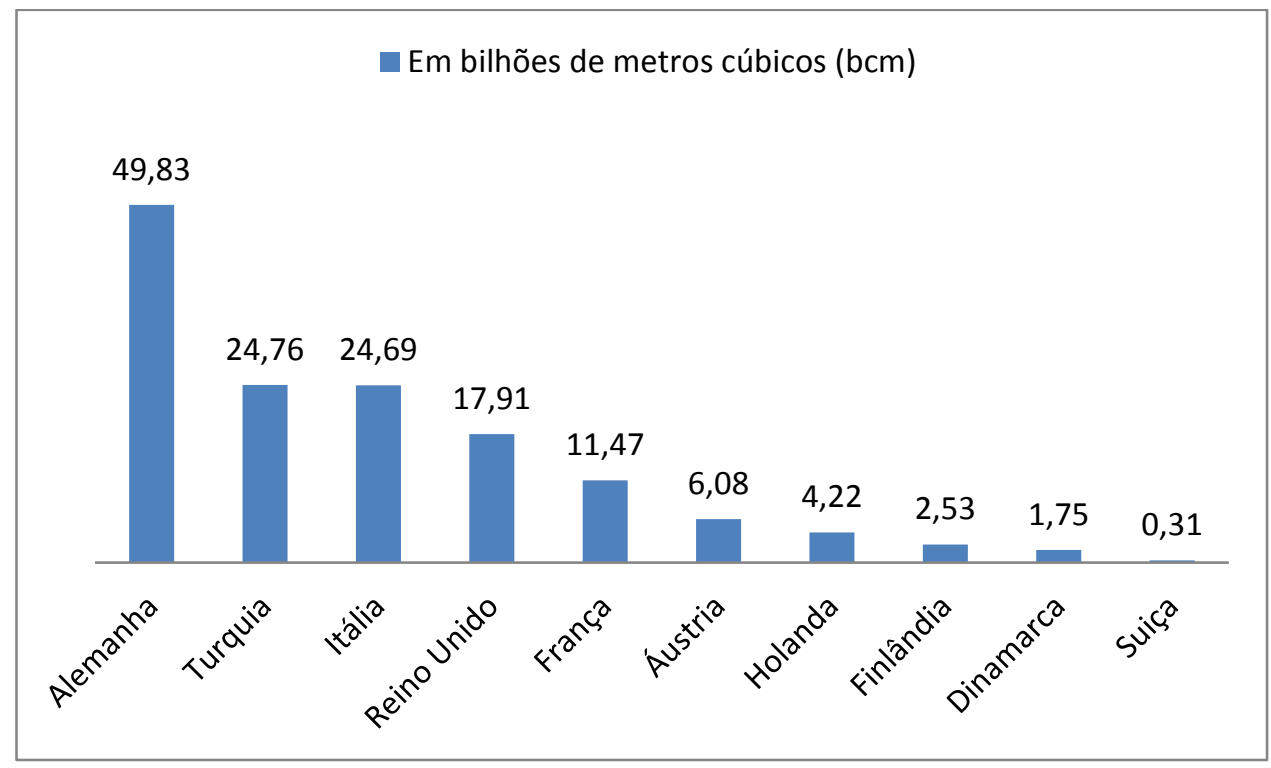

Elaboração Própria/Fonte: Gazprom

A parceria entre Rússia e Alemanha no setor de gás remonta a década de 1970, no contexto da Guerra Fria, quando foi estabelecido uma série de acordos triangulares (1970, 1972 e 1974) por meio dos quais os alemães financiariam a compra de equipamentos para a construção de gasodutos ligando campos de gás no território soviético à República Federal Alemã, com a contrapartida final de fornecimento de gás pelos russos. Em 1980, 16\% do gás consumido na RFA, e 6\% do petróleo, provinham da Rússia (STENT, 2013).

$\mathrm{O}$ anúncio do primeiro acordo foi surpreendente. À época, a RFA ainda se recusava a reconhecer a divisão da Alemanha e a incorporação de antigos territórios alemães à URSS, à Polônia e à Tchecoslováquia, além de se recusar a manter relações diplomáticas com qualquer país que tivesse reconhecido a República Democrática Alemã, com exceção da URSS (STENT, 1999). Ainda assim, Moscou e Bonn seguiram adiante com as negociações, firmando o maior negócio entre os dois países até então (HÖGSELIUS, 2013).

O impulso para a reaproximação com os soviéticos partiu do chanceler ${ }^{66}$ alemão Willy Brandt, que se mostrou disposto a reconhecer o status quo das fronteiras na Europa Central. A RFA aceitou os termos de Moscou, possibilitando a normalização das relações

${ }^{66}$ O Poder Executivo na Alemanha é liderado pelo chanceler federal (Bundeskanzler), equivalente ao cargo do primeiro-ministro de outros regimes parlamentaristas. 
(STENT, 1999), ainda que a aproximação entre URSS e RFA já viesse ocorrendo antes da eleição de Brandt em setembro de 1969.

Antes de se tornar chanceler, Brandt foi ministro das relações exteriores (19661969), período em que introduziu uma série de políticas destinadas a melhorar os laços com a Alemanha Oriental e com os soviéticos. Juntamente com seu conselheiro Egon Bahr, Brandt buscou substituir a antiga política alemã em relação ao Leste (Ostpolitik) por entender que a recusa em reconhecer os limites territoriais estabelecidos em Yalta e Potsdam não tinha produzido os resultados esperados. O objetivo principal passou a ser conseguir a reunificação alemã por meio da reaproximação com o Leste, não pela confrontação. Essa política foi consubstanciada no lema Wandel durch Annäherung (“mudança por aproximação"), cunhada por Bahr (STENT, 1999; HÖGSELIUS, 2013).

A ascensão de Brandt a chanceler, em 1969, permitiu que sua Ostpolitik fosse implementada de forma muito mais contundente do que era possível sob o governo de coalizão entre os socialdemocratas e democratas-cristãos ${ }^{67}$. A ênfase passou da cooperação econômica e técnica para questões-chave de política externa ligadas a interesses nacionais fundamentais. Brandt e Bahr imediatamente se propuseram a analisar as perspectivas de um tratado governamental com a União Soviética que regulasse questões fronteiriças sensíveis e, por extensão, as relações da República Federal com a RDA (HÖGSELIUS, 2013).

Do lado soviético, a administração de Leonid Brezhnev - que esteve à frente do governo soviético de 1964 até 1982 - esperava que os laços mais estreitos com a RFA pudessem legitimar o status quo vigente (a existência de duas Alemanhas), enfraquecer os vínculos da RFA com os Estados Unidos e a aliança ocidental, além de obter maior acesso à opinião pública da Alemanha Ocidental, explorando a insatisfação de alguns setores com a política externa norte-americana, decorrente principalmente do conflito do Vietnã (STENT, 1999).

Em 1970, foram assinados os Tratados de Moscou e Varsóvia, confirmando a divisão geográfica entre as duas Alemanhas e a fronteira com a Polônia, ao longo dos rios Oder e Neisse. Em 1972, RFA e RDA assinaram o tratado de reconhecimento mútuo ("Tratado Básico"). A insistência da Alemanha Ocidental em um relacionamento especial

\footnotetext{
${ }^{67}$ Em 1966, os socialdemocratas e os democratas-cristãos formaram um governo de coalizão. Brandt, socialdemocrata, tornou-se ministro das relações exteriores e vice-chanceler do democrata-cristão Kurt Kiesinger. Em 1969, no entanto, os socialdemocratas conquistaram uma vitória histórica. Pela primeira vez, os democrata-cristãos não fariam parte do governo federal. Um governo de coalizão foi formado pelos socialdemocratas e os democratas livres.
} 
com a sua parte oriental mostrou-se bastante vantajosa para a RDA. O comércio entre as duas Alemanhas foi considerado comércio interno, tornando a RDA um membro, de fato, da Comunidade Europeia (STENT, 1999). Em 18 de setembro de 1973, Alemanha Ocidental e Alemanha Oriental foram admitidas como membros da ONU.

Em 1974, Brandt renunciou após revelações de que um assistente próximo, Gunter Guillaume, era espião da Alemanha Oriental. Em seguida, o também socialdemocrata Helmut Schmidt substituiu Brandt à frente do governo da Alemanha Ocidental. Schmidt deu continuidade às políticas de reaproximação iniciadas por Brandt. Durante seu mandato, que se estendeu até 1982, Bonn, com o apoio de outros países da Comunidade Europeia, negociou com os soviéticos a construção do gasoduto Urengoy-Uzhgorod, apesar da forte oposição norte-americana.

Segundo Stent (1999), durante o mandato de Schmidt, Washington se desiludira com a política de distensão com a URSS (détente), finalmente declarando-a morta após a invasão soviética do Afeganistão. Nesse contexto, Schmidt era pressionado a "resfriar" as relações com Moscou. Do outro lado, as tensões transatlânticas eram vistas pelo Kremlin como uma oportunidade para dividir a aliança ocidental. No entanto, uma série de fatores impediram o esperado ganho político soviético, o mais significativo foi a denúncia de Schmidt à instalação de mísseis de médio alcance apontados para a Europa Ocidental, em 1977, com sua subsequente liderança no apoio europeu à instalação de mísseis da Otan em território alemão como contrapartida. Ainda assim, sob Schmidt, as relações com a Alemanha Oriental se intensificaram. A RFA aumentou significativamente os créditos financeiros oferecidos à RDA (STENT, 1999)

Em outubro de 1982, ascende ao poder o democrata-cristão Helmut Kohl, que havia se oposto a Ostpolitik de Brandt quando esta foi implementada, mas, por fim, passou a aceitá-la como fato consumado. Durante seu período à frente do governo alemão (19821998), Kohl intensificou relações com a Alemanha Oriental - oferecendo novas linhas de crédito - e desempenhou papel fundamental na promoção do PCA entre a UE e a Rússia, embora também tenha se engajado fortemente nas políticas de alargamento da UE e da Otan até às ex-repúblicas soviéticas (STENT, 1999; FREIRE; DAEHNHARDT, 2011).

Em 1994, Gazprom e Mannessmann (empresa alemã produtora de tubos de aço de carbono) assinaram acordos para a construção de um novo gasoduto ligando a Rússia e Europa (gasoduto Yamal-Europa, ver Figura 4). No entanto, em uma inversão da situação pré-1989, a Gazprom é que ficaria responsável por investir ativamente na infraestrutura energética alemã. Nessa época, a empresa russa já havia ingressado em uma 
série de joint ventures com a alemã Wintershall (subsidiária da Basf). Em 1993, Gazprom e Wintershall criaram a Wingas, maior produtora de petróleo e gás da Alemanha e importante distribuidora de gás em território alemão e países vizinhos. Em 1997, o investimento privado alemão na Rússia foi menor do que os investimentos da Gazprom na Alemanha (STENT, 1999; BROS; RICHARD, 2011).

Após a conclusão do projeto, em 1997, Gazprom e Wintershall começaram a planejar a construção de um segundo gasoduto, com o trajeto paralelo ao gasoduto YamalEurope, o Yamal-Europe 2, mas, posteriormente, decidiram substituí-lo pelo projeto Nord Stream, que atravessaria o Mar Báltico, evitando assim passar por outros países (ver Figura 4). Na época, o novo chanceler alemão, o socialdemocrata Gerhard Schröder, empenhou-se pessoalmente no projeto, o qual enfrentava forte oposição dos países bálticos e da Polônia. ${ }^{68}$ A objeção ocorria, entre outros motivos, em razão da perda das receitas advindas do trânsito do gás pelos territórios desses países. Além disso, Finlândia e Suécia expressavam preocupações com o impacto ambiental do gasoduto no Mar Báltico.

Schröder foi bastante criticado por ser considerado excessivamente próximo a Putin. Segundo os críticos, a proximidade do relacionamento entre os dois líderes políticos impedia o chanceler alemão de condenar publicamente o governo russo pelo seu crescente autoritarismo e pelos alegados casos de desrespeito aos direitos humanos (CÂMARA, 2013).

Em setembro de 2001, Putin foi convidado a discursar no Bundestag (parlamento alemão), ocasião em que se comprometeu com princípios democráticos e com a economia de mercado. Em seguida, Rússia e Alemanha estabeleceram o "Diálogo de Petersberg", com o objetivo de fortalecer os laços entre os dois países. Esses fatos, segundo Cruz (2013), simbolizaram o robustecimento das relações diplomáticas entre os dois países, as quais iriam atingir um patamar inédito em 2003, quando a Alemanha, juntamente com Rússia, França e China recusaram a proposta norte-americana de invasão do Iraque (CRUZ, 2013).

Em setembro de 2005, Schröder e Putin finalmente assinaram o acordo para a construção do Nord Stream. Logo após deixar o governo, em outubro daquele ano, o ex-

\footnotetext{
${ }^{68} \mathrm{O}$ projeto do gasoduto Nord Stream foi comparado pelo governo polonês ao Pacto Molotov-Ribbentrop, de 1939, pelo qual alemães e soviéticos combinaram a invasão e a ocupação da Polônia.
} 
chanceler alemão tornou-se presidente do conselho administrativo do consórcio responsável pelo Nord Stream ${ }^{69}$, liderado pela Gazprom.

Com a vitória dos democratas-cristãos em 2005, liderados por Angela Merkel, a Alemanha reforçou sua política euroatlântica, buscando lidar com a Rússia de maneira mais cautelosa, adotando uma postura mais dura em relação ao Kremlin, criticando a situação dos direitos humanos e das liberdades democráticas na Rússia. Conforme observam Freire e Daehnhardt (2011, p. 182), "Merkel é mais cuidadosa que Schröder na verbalização das relações com a Rússia, temendo que um discurso demasiado generoso face à Rússia possa gerar tensões com os EUA e a Polônia, bem como com outros Estados europeus."

Não obstante, Merkel manteve uma postura comedida em relação às iniciativas lideradas pelos EUA no leste europeu, mostrando, por exemplo, pouco entusiasmo com a expansão da Otan na Europa Oriental, situação que é responsável por um dos principais pontos de atrito entre Moscou e as potências ocidentais. Em abril de 2008, durante a reunião da Aliança Atlântica em Bucareste, o governo alemão foi um dos principais opositores à proposta de adesão de Geórgia e Ucrânia, defendida por Estados Unidos e Reino Unido ${ }^{70}$. Em 2014, a chanceler alemã também rejeitou a ideia de uma presença de longo prazo de tropas da Otan na Polônia, conforme propunha o então primeiro-ministro polonês, Donald Tusk, com o apoio de Washington.

O comprometimento do governo Merkel de encerrar a geração de energia nuclear na Alemanha até 2022 - após o acidente de Fukushima, no Japão, em 2011 - torna a aproximação com Moscou cada vez mais necessária. O Nord Stream, que começou a funcionar em 2011, ainda não opera dentro da sua capacidade total, especialmente em razão das restrições impostas pela UE, as quais exigiam que o braço do gasoduto que está dentro do território do bloco (Opal) pudesse ser utilizado por outros fornecedores, forçando a Gazprom a fazer uso de apenas $50 \%$ da capacidade de operação. No entanto, em outubro de 2016, uma decisão da Comissão Europeia permitiu à empresa utilizar a capacidade total do gasoduto caso não haja concorrentes dispostos a fazer uso do restante. Tal decisão gerou bastante controvérsia entre os países-membros do bloco, pois foi

\footnotetext{
${ }^{69}$ Em 2005 foi criada a Nord Stream AG, 51\% de suas ações ficaram com a Gazprom. As alemãs Wintershall e E.ON Ruhrgas obtiveram 24,5\% cada (POUSSENKOVA, 2010).

${ }^{70}$ Nessa reunião, a Otan concordou com o ingresso de Croácia e Albânia, mas recusou o plano de adesão (Membership Action Plan - MAP) de Geórgia e Ucrânia. Segundo Câmara (2013, p. 259), "pesaram, nesta decisão, os interesses alemães no relacionamento com Moscou e o reconhecimento tácito da área de influência russa em alguma das ex-repúblicas da União Soviética”.
} 
tomada quando UE e Rússia se posicionavam em lados opostos na Guerra da Síria. A decisão permitiu à Gazprom desviar, ainda mais, sua rota de escoamento de gás do território ucraniano, privando este país - que se encontra em uma situação delicada em razão dos embates militares com a Rússia - das receitas de trânsito.

Desde antes da liberação da Comissão Europeia, Berlim e Moscou vinham discutindo a possibilidade da construção de um segundo gasoduto paralelo ao Nord Stream, o Nord Stream 2, com a Gazprom liderando um consórcio de empresas europeias. Tal projeto também tem gerado bastante controvérsia, especialmente em um período em que - devido ao conflito na Crimeia - a Alemanha deveria estar focada na imposição de sanções à Rússia.

O então primeiro-ministro italiano, Matteo Renzi, chegou a declara que a postura alemã era de "duplo padrão", pois apoiava as sanções contra a Rússia ao mesmo tempo em que seguia em frente com o acordo para a construção de um novo gasoduto com a Gazprom. Renzi se mostrou bastante incomodado pelo fato de seu país ter sofrido perdas econômicas com as sanções à Rússia, enquanto a Alemanha continuou trabalhando em conjunto com Moscou (GEBAUER, 2016).

A imposição de novas sanções pelo Congresso norte-americano à Rússia, em julho de 2017, devido à suposta interferência de Moscou nas eleições americanas, deverá, de fato, prejudicar o andamento do projeto, o que gerou consternação na administração Merkel. O governo alemão criticou as novas sanções e as classificou como uma interferência nos assuntos energéticos europeus (STENT, 2017; WAGSTYL, 2017). Alguns analistas inclusive viram na imposição de novas sanções uma maneira de os Estados Unidos aumentarem suas exportações de gás para a Europa.

A resistência alemã em impor medidas mais duras à Rússia demonstra que a necessidade de acesso aos recursos energéticos deste país tem contrabalançado o relacionamento bilateral em favor de Moscou. Em contraste com a postura de outras potências ocidentais, notadamente Estados Unidos e Reino Unido - e mesmo com o posicionamento de países menos poderosos, como Ucrânia e Polônia -, que defendem políticas mais agressivas para conter a atuação russa no cenário internacional, os diferentes governos alemães, de modo geral, têm preferido não antagonizar a Rússia, preservando os interesses econômicos do país e assegurando suprimentos de energia. A interdependência entre Rússia e Alemanha é crescente, o que comprova a eficácia da Gazprom como instrumentos de política externa russa em relação a Berlim. 


\subsection{A Gazprom e a Ucrânia}

A Ucrânia é historicamente o principal corredor de distribuição do gás oriundo da Rússia para a Europa Ocidental. Atualmente, aproximadamente $60 \%$ do gás que vai para a Europa passa por gasodutos que atravessam o território ucraniano (TASS, 2015; OPDHAL, 2015). À época da dissolução da União Soviética, cerca de $90 \%$ das exportações de gás da Rússia passavam por esse país (VICTOR; SAFYER, 2011). Em décadas recentes, em razão dos inúmeros desentendimentos entre Moscou e Kiev, novos gasodutos vêm gradualmente diminuindo a importância do território ucraniano como rota de trânsito para o continente europeu. Considerando os novos projetos em andamento, a Gazprom planeja abandonar completamente os suprimentos de gás à Europa Ocidental através do território ucraniano a partir de 2018 (TASS, 2015).

Destaque-se que, ao longo de todo o período soviético, a Rússia forneceu energia a preços subsidiados a todos seus aliados, da Tchecoslováquia a Cuba (o fornecimento ocorria frequentemente por meio de permutas). Durante a primeira década depois do fim da URSS, os russos continuaram vendendo energia a preços abaixo do valor de mercado para aqueles países considerados estratégicos ou aliados próximos, a exemplo de Armênia, Belarus e Ucrânia (MOLCHANOV, 2015). A ameaça ou a tentativa de retirada desses subsídios nos anos que se seguiram ensejaram acusações de que Moscou utilizava o acesso a seus recursos energéticos como uma ferramenta política. A depender da linha de política externa adotada pelo Estado importador, ele poderia ser recompensado ou retaliado.

A economia ucraniana é fortemente dependente do gás da Rússia. Segundo Yergin (2012), ela é a mais intensiva no uso de energia do mundo e, durante anos, instituições internacionais como o Banco Mundial aconselharam o país a aumentar os preços do gás consumido internamente para melhorar a eficiência energética, mas o governo resistia por medo do impacto que o aumento poderia causar na indústria, em postos de trabalho e na renda da população.

As disputas em relação ao preço do gás entre Rússia e Ucrânia remontam à década de 1990. Durante o período soviético, quando os campos de gás presentes no território ucraniano começaram a se esgotar, o fornecimento de energia ao país passou a ser subsidiado e, após o desmembramento da URSS, os subsídios foram sendo gradualmente reduzidos. À medida que os preços aumentavam, Kiev se endividava cada vez mais com 
a Gazprom. Os primeiros cortes no fornecimento de gás ocorreram ainda em 1992 (CLOSSON, 2009).

Em 1997, começa a operar o gasoduto Yamal-Europa, ligando a península ártica de Yamal à Alemanha, através de Belarus e Polônia, intencionalmente reduzindo o papel da Ucrânia como país de trânsito (AALTO; WESTPHAL, 2008; POUSSENKOVA, 2010). No mesmo ano, Moscou e Kiev chegaram a um acordo sobre a situação da frota soviética estacionada no porto de Sevastopol, no Mar Negro. Pelo Acordo de Paz e Amizade, Moscou, que ficou com a maior parte da frota após o desmembramento da URSS, reconheceu a península da Crimeia como parte da Ucrânia ao passo que Kiev arrendou as instalações de Sevastopol à Rússia por vinte anos ${ }^{71}$ (ORTEGA, 2009).

A partir de 2000, as disputas em relação ao preço do gás começam a chamar atenção dos países ocidentais, uma vez que os cortes de gás à Ucrânia passaram a afetar também a Europa Central e Ocidental. Em 2006, por exemplo, após o corte da Gazprom, os ucranianos desviaram parte do fornecimento destinado a outros países para o abastecimento interno. Situação que reascendeu as preocupações europeias em relação à dependência dos recursos energéticos russos e abalou a imagem da Gazprom como um fornecedor confiável.

A interrupção de 2006 ocorreu após a chamada "Revolução Laranja", evento que se insere no contexto das chamadas "Revoluções Coloridas". ${ }^{72}$ A "Revolução Laranja" teve início após as eleições para a presidência realizadas no segundo semestre de 2004, quando Viktor Yushenko - candidato que contou com o apoio dos Estados Unidos e da União Europeia - venceu as eleições no primeiro turno por uma margem pequena em

\footnotetext{
${ }^{71}$ A posse da Crimeia foi sempre um ponto de disputa entre russos e ucranianos. Esta península, habitada por povos tártaros desde a Idade Média, já pertenceu a diversos impérios e países. Tornou-se parte do Império Russo sob o comando de Catarina, a Grande, em 1783. Na década de 1940, Joseph Stalin empreendeu uma deportação em massa da população nativa, os tártaros, substituindo-os por russos étnicos. Em 1954, sem prever a desintegração da União Soviética, Nikita Krushchev transferiu a jurisdição da Crimeia para a Ucrânia, como um gesto de amizade, que não teria maiores consequências práticas. Pelo Acordo de Paz e Amizade de 1997 a Crimeia foi reconhecida como uma "província autônoma" da Ucrânia.

72 Em 2003, irrompe na Geórgia a chamada "Revolução das Rosas", o primeiro dos movimentos que ficaram conhecidos como "Revoluções Coloridas" - as demais seriam a "Revolução Laranja", na Ucrânia, em 2004, e a Revolução das Tulipas, no Quirquistão, em 2005. De modo geral, todos esses movimentos defendiam o fim da corrupção, das fraudes nos processos eleitorais e o estabelecimento de sistemas políticos mais democráticos. Para Moscou, as "Revoluções Coloridas" foram patrocinadas por atores ocidentais, por ONGs especialmente, que contavam com o apoio dos governos de seus países de origem, notadamente dos Estados Unidos.
} 
relação ao segundo colocado, Viktor Yanukovich, apoiado por Moscou ${ }^{73}$. No segundo turno, porém, Yanukovich venceu a disputa.

Importante destacar que as diferenças étnicas na Ucrânia refletem diretamente no seu processo eleitoral. Cerca de $18 \%$ da população ucraniana (que é de aproximadamente 45 milhões de pessoas) é etnicamente russa. Essa população concentra-se predominantes no leste do país e na Crimeia. Assim, a parte leste geralmente vota em políticos mais alinhados com Moscou, ao passo que a parte oeste costuma apoiar políticos que defendem o estreitamento das relações do país com o Ocidente.

Em 2004, após os partidários de Yushenko e observadores internacionais apontarem indícios de fraude nas eleições, manifestantes passaram a se reunir na praça central de Kiev em protesto (eles usavam roupas e bandeiras laranjas, cor escolhida para a campanha presidencial do Movimento Nossa Ucrânia, de Yushenko). Houve ainda pressões internacionais para que houvesse novas eleições. Nesse contexto, a Suprema Corte do país decidiu cancelar o resultado do segundo turno e convocar uma nova eleição, a qual, desta vez, foi vencida por Yushenko (ORTEGA, 2009).

Em $1^{\circ}$ de janeiro de 2006, a Gazprom decidiu extinguir os subsídios que eram concedidos à Ucrânia no fornecimento de gás, o que resultou em um aumento de preços de US\$ 50 para cerca de US\$ 230 por mil metros cúbicos. Nesse período, a dívida da Neftogaz (estatal ucraniana responsável pelo abastecimento de gás no país) junto à Gazprom já alcançava 1,3 bilhão de dólares (GOLDTHAU, 2008). Para Kiev, o aumento de preços era uma clara retaliação de Moscou à vitória do partido pró-Ocidente, o que estaria demonstrado pela manutenção dos preços baixos cobrados de outras exRepúblicas soviéticas: Belarus pagava à época apenas US\$ 47 por mil metros cúbicos, enquanto o aumento dos preços de Armênia e Geórgia chegaram a apenas US\$ 110 por mil metros cúbicos (BBC, 2006; GROMADZKI; KONONCZUK, 2007).

Diante do impasse nas negociações, a Gazprom cortou o fornecimento de gás à Ucrânia, que desviou o volume que seria destinado aos demais países europeus para seu abastecimento interno. Em um período em que o continente europeu enfrentava um inverno particularmente rigoroso, a circulação de gás diminuiu em cerca de $30 \%$, gerando

\footnotetext{
${ }^{73}$ Para Sakwa (2015), Yanukovich não pode ser considerado nem pró-russo nem pró-ocidental, mas um típico representante da corrupta oligarquia ucraniana, mais preocupado com sua carreira política e com seu enriquecimento pessoal do que com a disputa entre russos e ocidentais. As relações entre Yanukovich e Putin, segundo Sakwa, não eram boas. Putin, por exemplo, mantinha melhores relações com Yulia Timoshenko - uma das líderes da Revolução Laranja e chefe de governo de Yushenko - mas teve de lidar diretamente com Yanukovich quando ele se tornou presidente em 2010.
} 
inúmeros transtornos. Despois das acusações de ambas as partes e de pressões de membros da União Europeia para que o abastecimento fosse retomado, os dois países chegaram a um acordo. O preço do gás consumido na Ucrânia passou a custar US\$ 95 por mil metros cúbicos, o que foi possível em razão do estabelecimento de um complexo esquema de triangulação na venda do gás, o qual passou a envolver a empresa RosUkrEnergo - uma joint venture entre a Gazprom e dois empresários ucranianos (Dmytro Firtash e Ivan Fursin), com sede na Suíça. Esta empresa passou a revender na Ucrânia gás natural proveniente da Rússia e do Turcomenistão (BBC, 2006; ORTEGA, 2009; GROMADZKI; KONONCZUK, 2007).

Importante destacar que, desde a independência da Ucrânia, os fornecimentos de gás a esse país foram negociados por meio de empresas intermediárias, em que havia pouco conhecimento sobre seus verdadeiros proprietários. A primeira foi a Itera, em 1994, substituída por Eural Transgas em 2003, que, por sua vez, foi substituída pela RosUkrEnergo em 2006. Segundo Gromadzki e Kononczuk (2007), o motivo da opção da Gazprom por joint ventures intermediárias não está claro, uma vez que a empresa tem uma subsidiária que geralmente cuida de todo o setor de exportação, a Gazpromexport. De acordo com os autores, é possível que elas propiciem aos representantes das elites políticas e empresariais de ambos os países vantagens financeiras ilícitas.

Em 2009, ucranianos e russos voltaram a se desentender sobre o preço do gás. Desde 2008, a Gazprom buscava instituir na Ucrânia preços similares aos praticados na Europa Ocidental. Contudo, em um protocolo assinado em outubro daquele ano, Moscou consentiu com uma transferência mais gradual para o patamar de preços da Europa Ocidental, sob a condição de que a Neftogaz pagasse a dívida junto à empresa, que já ultrapassava dois bilhões de dólares. Como a Neftogaz não pagou todo o montante, a Gazprom elevou o preço do gás de US\$179,5 para US\$ 250 por mil metros cúbicos, mantendo a tarifa de passagem em US\$1,70 para o transporte de cada mil metros de gás por 100 quilômetros de percurso.

Em razão do não pagamento das dívidas e do impasse sobre o aumento dos preços, os russos cortaram o suprimento destinado à Ucrânia em $1^{\circ}$ de janeiro de 2009 , os ucranianos novamente desviaram o gás destinado aos demais países europeus para seu abastecimento interno, gerando inúmeros transtornos no continente. Stengen (2011) chama atenção para o fato de que, nessa época, Moscou buscava convencer a Europa da importância de se construir um gasoduto que evitasse os territórios dos países do leste europeu. A proposta de construção do Nord Stream sob o Mar Báltico, ligando 
diretamente Rússia e Alemanha, enfrentava forte oposição dos países da Europa do Leste e escandinavos. Assim, segundo Stengen, o corte no fornecimento também tinha a intenção de alertar os países da Europa Ocidental sobre a fragilidade das rotas existentes.

As negociações para a retomada do abastecimento foram encabeçadas pela então primeira-ministra ucraniana Yulia Timoshenko, que aboliu a intermediação da RosUkrEnergo. Em 2011, Timoshenko foi condenada a sete anos de prisão sob a acusação de que o acordo firmado com a Rússia foi prejudicial à Ucrânia e que, ademais, deveria ter sido aprovado pelo Conselho de Ministros na sua totalidade, e não apenas pela então primeira-ministra. Em 2010, Timoshenko perdera as eleições presidenciais para Yanukovich, que concorrera novamente.

Yanukovich, após assumir a presidência, renegociou o acordo de abastecimento com Moscou. Em troca de um desconto de $30 \%$ na compra do gás, concordou em estender o período de arrendamento da base naval de Sevastopol, que chegaria ao fim em 2017, por mais 25 anos, permitindo à frota russa utilizá-la até 2042 (Tratado de Kharkov). Em 2011, o gasoduto Nord Stram foi finalmente inaugurado, diminuindo a importância do território ucraniano e de outros países do leste europeu como rotas para o transporte de gás da Rússia para a Europa Ocidental.

O mais recente incidente envolvendo Ucrânia e Rússia ocorreu no início de 2014, quando manifestantes se reuniram na praça Maidan, em Kiev, para protestar contra o governo de Yanukovich, que, em dezembro de 2013, abrira mão de um Tratado de Associação com a União Europeia em favor de um pacote de ajuda econômica de quinze bilhões de dólares de Moscou. Ressalte-se que o acordo associativo com a UE previa a realização um programa de ajuste econômico, além de reforma do sistema judicial, em troca do aval político para um eventual ingresso da Ucrânia no bloco europeu. Previa, ainda, a extensão das regras energéticas da UE ao sistema de energia ucraniano ${ }^{74}$ (CRUZ, 2013; TSYGANKOV, 2016).

A proposta russa, em contrapartida, incluía novos descontos no preço do gás e não envolvia condicionalidades econômicas. Nesse período, o governo Putin tentava promover a consolidação da Comunidade Econômica Eurasiana, bloco econômico criado em 2010 como uma união aduaneira entre Rússia, Belarus e Cazaquistão. Em janeiro de 2015, o bloco foi renomeado União Econômica Eurasiana, recebendo, posteriormente, a

\footnotetext{
${ }^{74}$ Pouco antes da posse de Yanukovich como presidente, a Ucrânia ingressara no Energy Charter Treaty (ECT). Sua afiliação à política energética da União Europeia implicava, entre outras medidas, o desmembramento da estatal Neftogaz (BELYI, 2011).
} 
adesão da Armênia e do Quirquistão. Segundo Rutland (2015), o objetivo do governo russo era impelir o governo ucraniano a também aderir à nova união, o que não seria possível caso o país assinasse o acordo associativo com a UE.

Em fevereiro de 2014, após alguns manifestantes terem sido alvejados por atiradores escondidos nos prédios ao redor da praça, Rússia, UE e EUA concordaram em apoiar um governo de união nacional, o qual propunha, entre outras diretrizes, antecipar as eleições presidenciais. Logo em seguida, porém, o Parlamento ucraniano, pressionado pelos manifestantes da praça Maidan, decidiu ignorar o acordo e forçar Yanukovich a abandonar a presidência por unanimidade de votos. Yanukovich fugiu para a Rússia no dia seguinte.

Para Washington e Bruxelas, os acontecimentos na Ucrânia foram resultado de uma manifestação popular que desejava a caída de um governo corrupto. Já para Moscou, os protestos da praça Maidan foram patrocinados pelo governo norte-americanos, visando promover uma mudança de regime na Ucrânia, a fim de estender a sua área de influência no leste europeu.

Em decorrência da destituição de Yanukovich, grupos armados sem uniformes tomaram o controle de bases-chave na península da Crimeia com o apoio de Moscou, em 26 de fevereiro de 2014. Um referendo foi convocado para o dia 16 de março, no qual a população da Crimeia, majoritariamente de descendentes russos, votou amplamente pela independência da Ucrânia e reincorporação à Rússia ${ }^{75}$. Kiev, Bruxelas e Washington denunciaram o referendo como ilegal. Dois dias após o referendo, a península foi formalmente integrada à Rússia após a assinatura de um tratado entre Putin e líderes locais, o que foi novamente rechaçado pelos líderes ocidentais, que classificaram tal atitude como uma violação à soberania da Ucrânia e um desrespeito às normas do direito internacional. Em 27 de março, a Assembleia Geral da ONU aprovou a resolução 68/262 declarando o referendo inválido. ${ }^{76}$

A perda da Crimeia pode representar mais um fator de vulnerabilidade energética para a Ucrânia, uma vez que passará à Rússia o direito de explorar os recursos minerais presentes na zona econômica exclusiva do entorno da península. Estima-se que essa região também seja rica em petróleo e gás (BROAD, 2014). Para a Rússia, a tomada da

\footnotetext{
75 A população de russos étnicos na Crimeia é de aproximadamente 58\% (RUTLAND, 2015). Estima-se que $83,1 \%$ dos cidadãos da Crimeia votaram no referendo em que a incorporação à Rússia foi aprovada por $96,7 \%$ dos votos.

${ }^{76} 100$ países votaram a favor da resolução 68/262, 11 contra, 58 se abstiveram, entre eles, o Brasil.
} 
península também garante que o país poderá seguir mantendo sua frota naval ancorada em Sevastopol. A possibilidade de perder o acesso a essa base fundamental no Mar Negro era uma das principais preocupações russas caso a Ucrânia ingressasse na Otan.

Em abril de 2014, a Gazprom, mais uma vez, interrompeu o abastecimento de gás à Ucrânia. O motivo foi o não pagamento da dívida da Neftogaz com a empresa russa. Após a destituição de Yanukovich, a Gazprom informou que retiraria os descontos concedidos anteriormente, o que resultou em um aumento de preços de cerca de $40 \%$. O fornecimento foi normalizado após um acordo envolvendo Bruxelas, Kiev, Moscou e o FMI em outubro de 2014. Para ajudar no pagamento da dívida, a UE emprestou a Ucrânia cerca de 760 milhões de euros, ao passo que o FMI contribuiu com 1,4 bilhão de dólares (ABELLÁN; FARIZA, 2014).

Após a incorporação da Crimeia, a Rússia foi expulsa do G8 e Washington pressionou pela imposição de sanções econômicas contra o país. Em um primeiro momento, contudo, nações importantes do bloco europeu, em especial a Alemanha, se opuseram a aplicação de sanções, que consideravam contraproducentes, mas, sobretudo, repercutiriam negativamente também em suas economias. Entretanto, em 17 de julho de 2014, uma aeronave da Malaysia Airlines, que voava de Amsterdã para Kuala Lampur, foi derrubada por um míssil russo, matando todas as 298 pessoas a bordo. Evidências sugerem que o míssil foi disparado por separatistas da região de Donbas. ${ }^{77}$ Depois desse fato, a UE concordou com a aplicação de sanções. Por conseguinte, as conversações para a renovação do PCA foram suspensas. Moscou, em retaliação, proibiu a importação de alimentos provenientes da UE e dos EUA.

A Ucrânia representa uma área de interesse vital para os russos. É do interesse de Moscou evitar principalmente que a Ucrânia ingresse na Otan, o que poderia abrir caminho para a instalação de mísseis e outros armamentos militares em território ucraniano, tornando a segurança do Estado russo bastante vulnerável. Além disso, Moscou alega a necessidade de se preservar a identidade cultural dos descendentes russos que vivem naquele país. Entre todas as ex-repúblicas soviéticas, a Ucrânia representa um

\footnotetext{
77 Donbas é uma abreviação referente à região da bacia do rio Donetsk (Donetsk Basin) e compreende, grosso modo, as regiões de Donetsk e Luhansk no leste da Ucrânia. Essa região sofre forte influência da cultura russa, sendo o russo a língua mais falada. No início de março de 2014, após a tomada da Crimeia por militares russos, rebeldes pró-Rússia começaram a ocupar edifícios oficiais nas cidades do sul e do leste da Ucrânia, mas somente em Donetsk e Luhansk eles conseguiram tomar o controle de fato. Em abril, o governo de Kiev lançou uma "operação antiterrorista" para retomar os territórios rebeldes, mas ela fracassou (RUTLAND, 2015). Hoje os combates se encontram em um impasse. As potências ocidentais acusam Moscou de oferecer apoio militar aos rebeldes, o que Moscou nega.
} 
caso especial para Moscou. Um dos mitos fundadores de origem da nação eslava remonta ao Estado kievano ou Rus' (terra russa) kievana, que existiu do século IX ao XIII. O leste da Ucrânia tem sido uma parte integrante da Império de Moscou por mais de três séculos (SAKWA, 2015).

Observa-se que, diferentemente do que ocorre em relação à Alemanha, a forte dependência ucraniana dos recursos energéticos russos não garantiu um maior alinhamento da política externa de Kiev aos interesses de Moscou. Desde o fim da URSS, diferentes governos ucranianos tem buscado se livrar da influência russa e se integrar às instituições ocidentais, notadamente à União Europeia e à Otan.

No final da década de 1990, o governo ucraniano se empenhou na criação do GUAM, grupo formado por Geórgia, Ucrânia, Azerbaijão e Moldávia ${ }^{78}$. O GUAM tem como característica principal ser um bloco formado por ex-repúblicas soviéticas sem a participação da Rússia. Um de seus principais objetivos, previsto em sua carta fundadora, está o de buscar integrar-se às instituições europeias. Em 2003, demonstrando seu alinhamento ao panorama política ocidental, todos os países-membros do GUAM enviaram um pequeno contingente militar ao Iraque (ORTEGA, 2009; FERRARO Jr., 2011).

A anexação forçada da Crimeia pela Rússia demonstra que os instrumentos econômicos à disposição de Moscou não foram suficientes para obter do governo ucraniano uma conduta mais condizente com os interesses russos. Um dos motivos para isso é o fato de que, ao longo dos anos, Kiev ter conseguido fazer uso de sua localização geográfica privilegiada para barganhar com Moscou. No entanto, à medida em que novos gasodutos entre Europa e Rússia foram sendo construídos, sua margem de manobra foi se tornando cada vez mais limitada.

Essa dinâmica, porém, não tem conseguido impedir Kiev de assumir uma postura hostil em relação a Moscou em diversas ocasiões. Outros fatores, como um histórico de ressentimentos e desconfianças em relação aos russos, também concorrem para essa postura mais confrontacionista de Kiev, demonstrando que o poderio econômico exercido pela principal NOC russa não consegue, isoladamente, exercer influência política de modo a evitar que países fortemente dependente de seus recursos assumam posturas contrárias aos interesses de Moscou.

\footnotetext{
${ }^{78}$ O Uzbequistão fez parte do GUAM (então GUUAM) entre 1999 a 2005.
} 


\subsection{A Gazprom e a China}

Depois de um período de rivalidade durante a Guerra Fria, após o desmembramento da União Soviética, China e Rússia têm gradualmente se reaproximado. Tal processo ganhou maior ímpeto após a resolução de questões fronteiriças em 1996, possibilitando a declaração de uma parceria estratégica entre os dois países e a criação do grupo os "Cinco de Xangai", formado por China, Rússia, Cazaquistão, Quirguistão e Tadjiquistão - mais tarde transformado na Organização de Cooperação de Xangai (OCX), um mecanismo de consultas mútuas com o objetivo de cooperar nas áreas econômica, cultural e de segurança. ${ }^{79}$

A questão energética representa um aspecto fundamental dessa relação. Características naturais e geográficas ajudam no incremento das trocas nesse setor, uma vez que a Rússia é rica em hidrocarbonetos e a China tem uma enorme demanda por energia. Para a Rússia, o mercado chinês é extremamente importante em razão de sua potencialidade e de representar uma alternativa às restrições e sanções impostas pelos países europeus.

Desde a abertura econômica chinesa, no final do século $\mathrm{XX}$, o consumo de energia no país tem aumentado exponencialmente ${ }^{80}$. A China já é o maior consumidor mundial de energia e, em 2014, tornou-se o maior importador de petróleo. Para Pequim, o acesso aos recursos russos tem a vantagem da proximidade geográfica, reduzindo a dependência chinesa do petróleo do Golfo Pérsico, transportado pelo mar e, portanto, mais suscetíveis a contratempos e interrupções. Em 2016, pela primeira vez na história, a Rússia superou a Arábia Saudita como principal fornecedor de petróleo à China (AIZHU; MENG, 2017). ${ }^{81}$

No entanto, o relacionamento entre os dois países também enfrenta desconfianças mútuas, particularmente devido à competição por áreas de influência econômica e política na Ásia Central. Em razão do legado soviético, durante muito tempo, os países ricos em hidrocarbonetos da Ásia Central foram obrigados a vender seus recursos à Gazprom, uma vez que a empresa era a única a possuir infraestrutura necessária para levar esses recursos

\footnotetext{
79 Em 2001, o Uzbequistão ingressou no "Grupo dos Cinco", que se transformou na OCX. Em junho de 2017, Índia e Paquistão também aderiram formalmente à organização.

${ }^{80}$ Estima-se que a demanda de energia da China tenha crescido mais de 500\% desde 1980. Em 1994, o país se tornou importador líquido de petróleo.

${ }^{81}$ A origem do petróleo consumido na China é bastante variada. Entre seus principais fornecedores - além de Rússia e Arábia Saudita - estão Irã, Líbia, Sudão, Sudão do Sul, Omã, Iraque, Emirados Árabes Unidos, Angola e Venezuela (EIA, 2014).
} 
até o principal mercado consumidor: a Europa. Em 2009, contudo, foi inaugurado o primeiro gasoduto ligando a região ao território chinês - saindo do Turcomenistão e chegando em Xinjiang, na China -, simbolizando o fim do monopólio russo sobre o transporte do gás na Ásia Central. Em 2010, o gasoduto foi ampliado, possibilitando ao Uzbequistão e ao Cazaquistão também exportarem seu gás para a China. Além disso, Pequim firmou diversos acordos de fornecimento de petróleo com esses países. Cooley (2012) chama atenção para o fato de os países da Ásia Central estarem se mostrado bastante hábeis em barganhar entre China e Rússia, especialmente aqueles ricos em recursos naturais, como o Cazaquistão (rico em petróleo) e o Turcomenistão (rico em gás).

Em 2014, a China lançou a iniciativa intitulada a "nova Rota da Seda" - mais tarde renomeada One Belt One Road (OBOR) -, com objetivo de financiar projetos de infraestrutura em áreas que compreendem partes da Ásia Central, do Oriente Médio e da Europa. No passado, essas localidades eram o caminho por qual passava o fluxo de bens entre a China e o Mediterrâneo. Nessa mesma época, no entanto, o governo russo vinha se empenhando na consolidação da União Econômica Eurasiana, que tem entre seus objetivos o estabelecimento de uma moeda única: o rublo, concorrendo com os planos chineses de internacionalização do renminbi.

Apesar das tensões iniciais, em maio de 2015, Putin e Xi Jinping assinaram uma declaração conjunta de cooperação e coordenação entres as duas iniciativas, iniciando negociações sobre um acordo de comércio e investimento entre a China e a União Eurasiana. Segundo Gabuev (2016), o Kremlin teria concluído que os benefícios de uma integração econômica com os chineses na região ultrapassava os riscos de perda de influência na Ásia Central. Desse modo, ainda que o predomínio da China na Ásia Central possa gerar novos atritos com Moscou, por enquanto, empresas chinesas e russas são parceiras em projetos na região.

Conforme observa Pimentel (2011), a China está bastante interessada nos recursos energéticos da própria Rússia, o que a impediria de assumir uma postura de concorrência aberta com Moscou na Ásia Central. Pequim tem buscado, portanto, uma postura de acomodação com os interesses russos por meio de iniciativas como a OCX. Em 2007, foi criado no âmbito dessa organização o "Clube da Energia", com o objetivo principal de alinhar os sistemas de fornecimento e consumo dos países-membros (ADAM, 2012). Além desse fórum, os dois países têm estreitado suas relações em outras instâncias multilaterais - como no Brics e em seu Novo Banco de Desenvolvimento (NBD), no 
Banco Asiático de Investimento em Infraestrutura, no G20 Financeiro, no Conselho de Segurança da ONU, etc. - e aumentado a integração econômica e energética.

Após a crise de 2008, que afetou severamente a economia russa, companhias privadas e estatais buscaram empréstimos junto ao governo chinês. Em 2008, a Rosneft e a Transneft tomaram emprestado 25 bilhões de dólares do Banco de Desenvolvimento Chinês, em um esquema denominado por alguns de "empréstimo por energia". O governo russo se comprometeu a entregar à China 15 milhões de toneladas de petróleo por ano, de 2011 a 2015, em troca do empréstimo. O contrato também envolveu a construção de ramificações do oleoduto ESPO (East Siberia - Pacific Ocean) - que liga o leste da Sibéria ao Oceano Pacífico - em território chinês. Ademais, a Gazprom anunciou que as transações feitas pelo ESPO para os clientes chineses seriam realizadas em renminbi (GABUEV, 2016; MANKOFF, 2011).

Em 2014, a Gazprom e a estatal chinesa PetroChina - subsidiária da China National Petroleum Corporation (CNPC) - chegaram um acordo para o fornecimento de cerca de 70 bilhões de metros cúbicos por ano de gás durante trinta anos. $\mathrm{O}$ acordo também compreende a construção de novos gasodutos ligando a Sibéria à China. ${ }^{82}$ As negociações tiveram início ainda em 2004, mas estavam paralisadas em razão de divergências sobre o preço do gás. No entanto, as recentes sanções impostas por Estados Unidos, Europa e Japão à Rússia, impeliram Moscou a aceitar um preço menor por parte dos chineses. Caso o acordo entre Gazprom e CNPC se concretize, a China se tornará o principal cliente da Gazprom, posto hoje ocupado pela Alemanha, o que tem gerado especulações sobre a sustentabilidade dos recursos energéticos russos diante de um aumento expressivo da demanda e sobre as consequências dessa parceria para a segurança energética da Europa.

Conforme observa Skalamera (2015), a Rússia dispõe de poucas alternativas para voltar a crescer: ao mesmo tempo em que precisa continuar vendendo hidrocarbonetos para manter sua economia funcionando, a extração desses recursos se torna mais complexa a cada dia. À medida que as antigas reservas vão se exaurindo, é preciso iniciar operações em áreas cada vez mais inóspitas. Para isso, são necessários recursos tecnológicos e econômicos. Neste quesito, a China tem se mostrado um aliado

\footnotetext{
${ }^{82}$ Estuda-se a construção de dois gasodutos: o Sila Sibiri (“O poder da Sibéria”) ligando o leste da Sibéria (campos de Kovykta e Chayanda) à China, o qual forneceria 38 bilhões de metros cúbicos anualmente até 2030; e o Altai, ligando o oeste da Sibéria ao noroeste China, o qual forneceria 30 bilhões de metros cúbicos anualmente até 2030.
} 
importantíssimo de Moscou por meio de financiamentos. Não obstante, no que se refere ao desenvolvimento de tecnologia para a exploração de petróleo e gás, Skalamera avalia que a China não dispõe da expertise de que a Rússia necessita para a manutenção de seus atuais níveis de produção, o que compreenderia aumentar a extração em áreas mais difíceis, como no Ártico, onde é necessário o emprego de modernas técnicas de exploração (SKALAMERA, 2015; HILL; LO, 2013).

Do lado da Rússia, Lo (2008) destaca que, embora muitos cidadãos russos admirem a China por seu sucesso econômico, a noção de uma "ameaça chinesa" (refletida na ideia xenofóbica de um "perigo amarelo") ainda persiste. Embora as percepções sobre a potência asiática possam ser mais positivas hoje que no passado, há muita desconfiança sobre quais seriam os verdadeiros interesses chineses. A integridade territorial da Rússia seria um dos principais motivos de preocupação, especialmente quando se observa as enormes riquezas minerais presentes no lado russo e a discrepância populacional e econômica da região fronteiriça: 77\% dos 143 milhões de russos vivem na parte ocidental do país (que corresponde a apenas $25 \%$ do território). O extremo oriente possui apenas 6,1 milhões de habitantes russos. Do lado chinês, a região da Manchúria, sozinha, concentra cerca de 110 milhões de habitantes (GIELOW, 2017; KHANNA, 2008; LO, 2008).

Para Lo (2008), o eixo Moscou-Pequim seria mais uma união de conveniência do que uma verdadeira aliança. Embora possa haver interesses comuns em áreas como energia, cooperação militar (a China é o principal consumidor de armamentos russos) e na contenção do unilateralismo norte-americanos, as desconfianças entre os dois países ainda seriam muito grandes. Assim, tal eixo de conveniência seria, em muitos aspectos, uma "anti-relação", construída mais para conter o desenvolvimento indesejável de outros atores - particularmente dos EUA - do que para criar novas estruturas e mecanismos de cooperação.

Gabuev (2016), por sua vez, observa que os interesses sobrepostos das duas grandes potências da região deverão superar suas diferenças. Segundo este autor, tanto Moscou quanto Pequim compartilham uma visão da Ásia Central liderada por regimes autoritários seculares, sem grandes conflitos interestatais e sem envolvimento externo. Dada a extensão do desengajamento dos Estado Unidos na região, com a gradual retirada 
de tropas americanas do Afeganistão ${ }^{83}$, e o relativo declínio da Rússia como um centro de gravidade econômico, Moscou e Pequim deverão encontrar maneiras de acomodar seus interesses mútuos. Gabuev (2016) ressalta porém que, nessa nova disposição de forças, a Rússia deverá desempenhar um papel de "sócio menor" (junior partner), com a China oferecendo a Moscou ajuda econômica e empenhando-se em mostrar deferência simbólica ao status da Rússia como uma grande potência. À Rússia caberia o papel de fornecer de recursos vitais aos chineses (tecnologia militar e civil, recursos naturais e apoio diplomático) a fim de impulsionar a ascensão da China como potência global capaz de competir com os Estados Unidos.

Por outro lado, é importante observar que o centro de gravidade do consumo de combustíveis fósseis está mudando dos Estados Unidos para a Ásia. Enquanto o consumo de petróleo dos países membros da OCDE deve diminuir em quase 25\% até 2040, o crescimento do consumo dos países não membros deve crescer em mais de 50\%, com China e Índia sendo responsáveis por mais de metade desse aumento. Em 2035, a China deverá superar os Estados Unidos como o maior consumidor de petróleo do mundo. Adicionalmente, devido ao desenvolvimento de algumas fontes fósseis alternativas na América do Norte, como o xisto e areias betuminosas (Canadá), o consumo americano depende cada vez menos do petróleo do Golfo Pérsico.

Nesse cenário, acredita-se que Washington irá, aos poucos, diminuir seus investimentos na segurança das rotas de petróleo do Oriente Médio, o que acarretará maiores custos para Pequim manter o abastecimento oriundo da região. Nessa conjuntura, um estreitamente de laços com a Rússia deve garantir a segurança energética chinesa a custos menores, aumentando o poder de barganha de Moscou e tornando o relacionamento bilateral mais equilibrado.

Atualmente, verifica-se que a necessidade de acesso aos recursos naturais russos pela China, bem como a necessidade de Moscou de explorar novos mercados e obter financiamentos, tem aproximado chineses e russos. Essa aproximação, todavia, não ocorre apenas em razão da interdependência energética. Rússia e China compartilham percepções semelhantes em muitas questões diplomáticas internacionais. Ambos os países buscam a constituição de uma ordem internacional multipolar, a qual diminuiria o peso do unilateralismo norte-americano. Além disso, ambos costumam assumir um

\footnotetext{
${ }^{83}$ Em agosto de 2017, o presidente Donald Trump anunciou o envio de mais quatro mil soldados ao Afeganistão, adiando os planos da administração de Barack Obama (2009-2016) de desengajamento na região.
} 
posicionamento soberanista em sua política externa, condenando ingerência em assuntos domésticos de países soberanos. Em relação à guerra na Síria, por exemplo, os governos chinês e russo têm sistematicamente vetado a aprovação de sanções contra o regime de Bashar al-Assad no Conselho de Segurança da ONU. Anteriormente, adotaram posicionamentos próximos nos casos envolvendo o programa nuclear iraniano, a guerra na Líbia, em 2011, e a invasão do Iraque, em 2003.

Essa afinidade no campo político incentiva o estreitamento das relações bilaterais. Desse modo, diferentemente do que ocorre em relação à Alemanha - em que a interdependência do mercado de energia representa um aspecto chave da relação, impedindo medidas mais duras de Berlim em relação à Rússia -, no caso da relação ChinaRússia, a dependência energética não representa o aspecto primordial do vínculo bilateral, ainda que seja essencial para a mitigação de eventuais atritos políticos nas áreas em que ambos têm seus interesses sobrepostos, como na Ásia Central.

\subsection{A Gazprom e a Turquia}

O território turco se encontra em uma localização estratégica para projetos de gasodutos e oleodutos que visam levar recursos dos países do entorno do Mar Cáspio até a Europa sem passar pelo território russo. Em anos recentes, à medida que a Rússia tem buscado evitar rotas de trânsito de gás que atravessem o território ucraniano, a Turquia tem procurado se estabelecer com um importante " $h u b$ " de energia (TSYGANKOV, 2016). Desde 2008, a Rússia é o principal parceiro comercial da Turquia, as transações envolvendo petróleo e gás são o componente mais importante da relação econômica. A Rússia fornece à Turquia cerca de $57 \%$ do gás natural consumido no país (MANKOFF, 2016).

Por outro lado, um dos principais objetivos da política externa norte-americana tem sido evitar que as rotas de escoamento da região do Cáspio sejam controladas por Irã ou Rússia. Nesse sentido, Washington tem patrocinado a construção de novos gasodutos e oleodutos que perpassam o território turco, em razão mais de preocupações políticas do que econômicas (HEINRICH, 2014).

Ainda na década de 1990, Irã e Turcomenistão propuseram a construção de um gasoduto ligando seus países à Europa por meio do território turco. No início da década de 2000, o projeto foi reavivado por americanos e europeus, mas excluindo o Irã em razão das desavenças políticas. Tal projeto ficou conhecido como Nabucco (também chamado 
de Trans-Caspian, Southern Gas Corridor, ou Fourth Corridor). A construção ficaria a cargo da austríaca OMV, em parceria com empresas estatais de seis países diferentes.

Em 2006, após a “guerra do gás” entre Rússia e Ucrânia, a União Europeia iniciou os estudos de viabilidade para a construção do gasoduto Nabucco. Em 2009, após o novo corte de fornecimento à Ucrânia, a Comissão Europeia se comprometeu a investir até 250 milhões de euros no projeto, enquanto o Banco de Investimento Europeu declarou que poderia financiar até $25 \%$ dos custos de construção. Em 2011, o presidente do Azerbaijão, Ilam Aliev, e o presidente da Comissão Europeia, José Manuel Barroso, assinaram uma declaração formal em que o país se comprometeu a fornecer a quantidade de gás necessária para a viabilidade do projeto (CRANDALL, 2011; ROBERTS, 2011).

O território turco representa uma peça fundamental para a consecução desse projeto. Sua posição geográfica e suas relações próximas com as potências ocidentais, bem como com os países do Cáspio e da Ásia Central, faz da Turquia um intermediário ideal para a distribuição desses recursos até a Europa. O projeto, contudo, está paralisado em razão da dificuldade de se negociar com todos os países envolvidos e da possibilidade de que os países fornecedores não disponham de recursos suficientes para tornar o projeto economicamente viável, uma vez que Rússia e Irã estão excluídos, restando apenas dois outros produtores significativos: Azerbaijão e Turcomenistão.

A figura a seguir mostra uma das prováveis rotas do projeto Nabucco: 


\section{Figura 8 - Mapa do Gasoduto Blues Stream e Provável Rota do Gasoduto Nabucco}

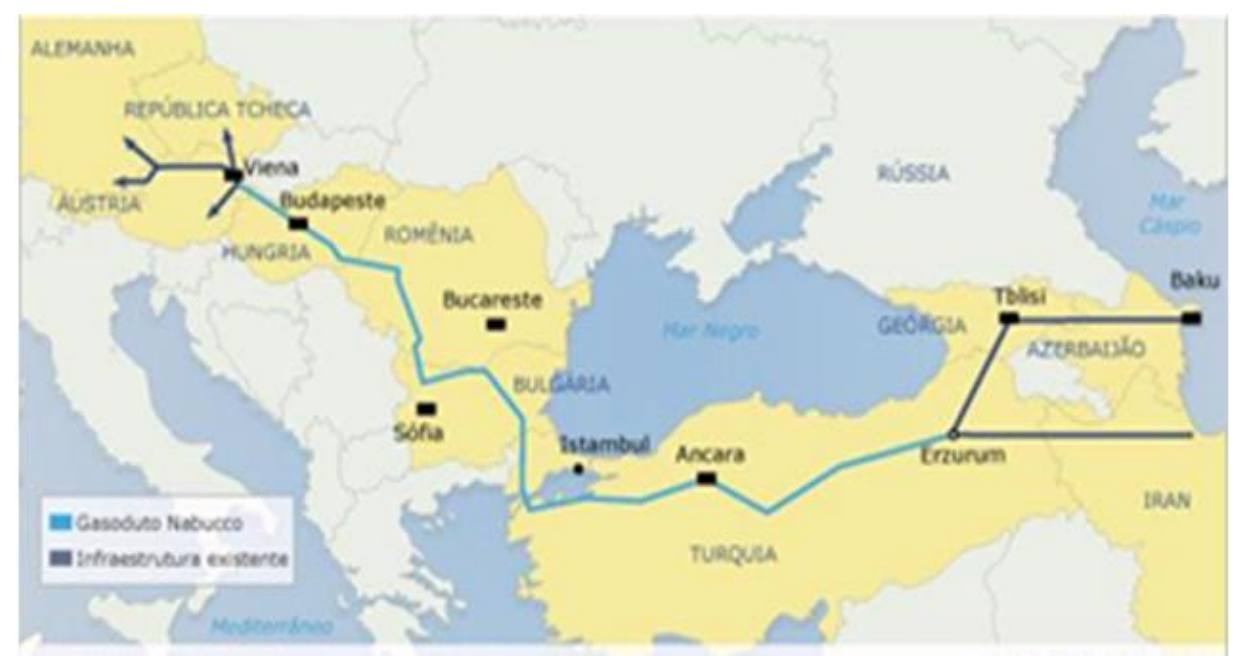

Fonte: Deutsche Welle

Para Goldman (2008), o Kremlin põe em prática uma ativa política de obstrução de construção do gasoduto Nabucco, inclusive por meio da desestabilização política de países que poderiam servir de rota para o projeto, a exemplo da Guerra na Geórgia em 2008. A Gazprom também passou a investir em projetos paralelos, a fim de mitigar a viabilidade econômica do projeto Nabucco.

Desde 2003, Rússia e Turquia dispõem de um gasoduto ligando diretamente os dois países, o Blue Stream (ver Figura 4). Este gasoduto foi construído pela Gazprom em parceria com a italiana ENI. No entanto, um mês após o início dos fornecimentos, Ancara parou de receber o gás, insistindo em alterações nos termos do contrato (reduções de preços e volume). Sem alternativas para a capacidade já instalada, Moscou concordou com as alterações - o fornecimento foi normalizado em 2005 -, o que resultou em um desastre comercial para a Rússia, mas em um sucesso geopolítico, conforme observou Poussenkova (2010), uma vez que prejudicou os planos de construção do Nabucco, pois a viabilidade econômica de um segundo gasoduto passando por uma rota semelhante ficou comprometida.

Em 2005, inaugurou-se o oleoduto Baku-Tbilisi-Ceyhan (BTC), em um consórcio liderado pela BP, viabilizando o transporte do petróleo de Baku, no Azerbaijão, até Ceyhan, na Turquia, passando pelo Cáucaso e evitando o território russo. Em 2006, foi a vez do gasoduto Baku-Tbilisi-Erzerum (BTE) - também chamado de "South Caspian pipeline", que seguiu uma rota paralela ao BTC. O BTC possibilitou ao Azerbaijão, país rico em petróleo e gás, desviar-se da infraestrutura da Gazprom para escoar seus recursos. 
Outros países da Ásia Central, como o Cazaquistão, também utilizam o BTC para exportar sua produção até o Cáucaso.

Atualmente, em razão da paralização do projeto Nabucco, apareceram outras alternativas para o transporte de gás dos países do Cáspio sem passar por território russo. Planeja-se, por exemplo, a construção do Trans Anatolian Pipeline (TANAP), que atravessaria a Turquia, e o Trans Adriático Pipeline (TAP), que atravessaria Grécia e Itália (WEISS, 2014). Um consórcio de empresas, liderado pela BP, já trabalha no projeto Shah Deniz 2, no Azerbaijão, que deverá enviar gás para a Europa através desses dois novos gasodutos. ${ }^{84}$ Mais uma vez, entretanto, especula-se que o volume produzido não seja suficiente para o abastecimento da Europa.

A Gazprom, por sua vez, planejava a construção de um segundo gasoduto (South Stream) ligando o Cáucaso russo até a Europa por uma rota que atravessa o Mar Negro, chegando até a Bulgária. A Rússia buscou atrair a participação dos países europeus para o seu projeto, o que inviabilizaria economicamente a construção de outros gasodutos. Em muitos casos, houve disputas entre os possíveis países de trânsito, todos querendo garantir que seu território se tornasse um " $h u b$ " de distribuição.

Entre 2008 e 2010, o Kremlin concluiu acordos intergovernamentais com vários Estados para a passagem do novo gasoduto. Em dezembro de 2013, porém, a Comissão Europeia declarou que tais acordos infringiam a legislação da UE e exigiu que seus Estados-membros renegociassem os acordos ou interrompessem a construção dos segmentos do South Stream em seus territórios. Em junho de 2014, a Comissão abriu dois processos de infracção contra a Bulgária sobre a violação do Terceiro Pacote de Energia, como resultado, o governo búlgaro ordenou a suspensão das obras relacionadas ao projeto (FRANZA, 2015; STERN; PIRANI; YAFIMAVA, 2015).

As exigências do TEP, além do processo antitruste que a Gazprom vem sofrendo do bloco europeu, fez a empresa desistir do projeto South Stream em dezembro de 2014. Em seguida, a empresa anunciou que planejava substituí-lo pelo Turkish Stream. Assim, em vez de um novo gasoduto até a Europa, construiria um novo gasoduto até a Turquia, paralelo ao Blue Stream, ficando os países europeus responsáveis pelo transporte do gás da Turquia até a Europa. As empresas parceiras da Gazprom no South Stream - a italiana ENI, a francesa EDF e a alemã Wintershall - se retiraram do projeto (RT, 2014).

\footnotetext{
${ }^{84}$ O Shah Deniz já abastece a Geórgia e a Turquia.
} 
A derrubada de um jato russo envolvido no conflito da Síria pelas forças armadas turcas, em novembro de 2015, gerou um rápido estranhamento do relacionamento entre Ancara e Moscou e pôs em cheque os planos de construção do Turkish Stream. Após o incidente, a Rússia impôs sanções econômicas à Turquia, embora o fornecimento de gás pelo gasoduto Blue Stream tivesses sido mantido. Em junho de 2016, após o pedido de desculpas feito por Recep Tayyip Erdogan, as relações foram retomadas. Analistas avaliam que Putin é um aliado mais cômodo a Erdogan do que os tradicionais parceiros ocidentais, os quais criticam a crescente repressão política na Turquia. Atualmente, há planos para uma ampliação do Blue Stream, aumentando sua capacidade de 16 para 19 bilhões de metros cúbicos (FRANZA, 2015).

Para além da importância de seu território como rota de trânsito, existe a possibilidade de a Turquia também se tornar um importante produtor de gás. Perfurações no Mediterrâneo, perto das costas de Chipre, Egito, Israel, Líbano, Síria e Turquia comprovaram a existência de vastas reservas de gás natural. A concorrência pelos direitos de exploração desses recursos deve agravar ainda mais as tensões existentes sobre a soberania e as fronteiras marítimas na região (ZHUKOV, 2013). Daí a importância da manutenção da base de Tardus, na Síria, pelos russos. A Gazprom, por sua vez, já vem atuando conjuntamente com outras empresas multinacionais (principalmente norteamericanas) no desenvolvimento do gigante campo de gás de Leviatã, na costa de Israel, o qual se estima conter cerca 17 trilhões de metros cúbicos de gás.

Ainda sobre os interesses estratégicos russos no território sírio, vale destacar que em julho de 2011, Irã, Iraque e Síria haviam concordado em construir um gasoduto ligando o campo de gás de South Pars, no Irã, ao Líbano e, de lá, para a Europa, atravessando o Mediterrâneo. O gasoduto seria construído pela Gazprom e teria a capacidade de transportar 110 milhões de metros cúbicos de gás. Cerca de um quarto do gás seria consumido pelos países de trânsito, deixando 70 milhões de metros cúbicos para serem vendidos para a Europa. No entanto, a eclosão da guerra na Síria frustrou a execução desse projeto (IMONTI, 2013). Atualmente, as reservas de South Pars têm sido desenvolvidas pela chinesa CNPC e pela francesa Total em conjunto com a estatal iraniana.

Verifica-se que, assim como ocorre na Ucrânia, a forte dependência turca dos recursos energéticos de Moscou tem sido mitigada em razão da localidade estratégica de seu território e do fato deste país ter sido historicamente um bastião da Otan na fronteira com a Rússia, o que possibilitou a Ancara barganhar entre os projetos de escoamento de 
hidrocarbonetos encabeçados pela Rússia e aqueles liderados pelas potências ocidentais. Diferentemente do governo ucraniano, entretanto, o governo turco tem sido igualmente cuidadoso no seu relacionamento com Moscou, Bruxelas e Washington, de modo a não antagonizar nenhuma das partes, buscando garantir que o país se torne o principal corredor de transporte de hdirocarbonetos entre Ásia e Europa. Todavia, a interdependência econômica entre Turquia e Rússia, em que o setor de energia se destaca, tem gerado benefícios para Moscou. Após a anexação da Crimeia, por exemplo, a Turquia foi o único país-membro da Otan a não impor sanções à Rússia. 


\section{CONCLUSÃO}

A disputa por hidrocarbonetos e a necessidade de se obter segurança energética são temas vitais para as relações internacionais. A disponibilidade de energia acessível a um Estado é de fundamental importância para o seu crescimento econômico, sua segurança nacional e mesmo para o bem-estar de sua população. Para países que são importantes exportadores de petróleo e gás, sua política energética pode constituir mais uma ferramenta de política externa.

Desse modo, a administração feita pelas NOCs dos recursos energéticos de seu país de origem também responde a interesses políticos. Essas empresas foram criadas para fazer mais do que simplesmente gerar lucros econômicos. A partir da década de 2000, a evolução dos preços dos hidrocarbonetos no mercado mundial ensejou o restabelecimento ou o fortalecimento das antigas NOCs, que voltaram a exercer um papel fundamental na política externa de seus países.

Nesse contexto, a tese defendida por este trabalho é a de que a Gazprom, a principal NOC russa, reflete em suas operações os interesses do Estado russo. Observase, ainda, que a utilização que tem sido feita desta empresa desde o começo deste século - início do primeiro governo de Putin - se difere fundamentalmente do que ocorreu no governo anterior, quando a administração de Yeltsin pôs em prática medidas liberalizantes.

A recuperação dos preços dos hidrocarbonetos no mercado internacional impulsionou a retomada dos ativos de energia pelo governo, possibilitando a Moscou fazer uso dessas novas estatais como instrumentos de política externa. Essa estratégia, de modo geral, mostrou-se eficaz, tendo contribuindo para fazer da Rússia, novamente, um ator fundamental nas relações internacionais em razão dos benefícios políticos e econômicos gerados por essas estatais revigoradas.

Tal fato foi constatado ao se analisar as relações da Rússia com três países: Alemanha, China e Turquia. Na Alemanha, principalmente, o acesso facilitado aos hidrocarbonetos russos mostrou-se um ponto de fundamental importância para sua política externa. Desde a década de 1970, todas as administrações à frente Estado alemão têm buscado limitar as restrições ao comércio com a Rússia. Ao mesmo tempo, empresas ligadas ao setor de energia engajam-se em iniciativas conjuntas com a Gazprom, aprofundando a interdependência econômica entre os dois países. Tal fato acaba conferindo a Moscou uma certa influência sobre as decisões políticas de Berlim, 
compelindo o governo alemão a se opor a punições mais duras à Rússia em instâncias multilaterais dominadas pelos países ocidentais.

Na China, a interdependência energética com a Rússia também representa um aspecto fundamental do relacionamento, embora outros fatores - como a apreensão em relação às ações militares das potências ocidentais e o ceticismo quanto as intervenções humanitárias realizadas em Estados soberanos - contribuam para o recorrente alinhamento político em âmbito internacional. O crescimento da influência chinesa no antigo espaço soviético, especialmente na Ásia Central, pode acabar por diminuir o poder da "arma energética" russa, uma vez que Pequim tem patrocinado a construção de rotas alternativas de escoamento de gás e petróleo. Por outro lado, as mudanças pelas quais passam o mercado de energia, com os Estados Unidos gradualmente se retirando do Oriente Médio, podem tornar uma maior interligação com a Rússia a alternativa mais economicamente viável para a China, reequilibrando o relacionamento em favor de Moscou.

Em relação à Turquia, observa-se, igualmente, que a dependência energética da Rússia representa um ativo importante em favor de Moscou na relação bilateral. Há expectativas em Ancara - ainda mais após a imposição de sanções à Rússia e de medidas antitruste à Gazprom - que o território turco se torne um importante centro de distribuição de energia para a Europa. Tal fato aumentaria a força política da Turquia, porquanto os europeus estariam mais dependentes do seu território como rota de trânsito dos hidrocarbonetos. Para isso, boas relações com Moscou são essenciais. Ressalte-se, contudo, que a localização estratégica do território turco permite a Ancara barganhar entre projetos de infraestrutura energética encabeçados pelas potências ocidentais e pela Rússia, gerando uma certa compensação no relacionamento com Moscou, impedindo, assim, que haja uma excessiva influência russa sobre a Turquia.

Na Ucrânia, em contraposição aos três casos anteriores, o gerenciamento feito por Moscou de seus recursos energéticos não tem sido eficaz. Este país, mesmo sendo fortemente dependente dos hidrocarbonetos russos, vem adotando uma postura claramente contrária aos interesses de Moscou. O interesse das grandes potências mundiais, notadamente dos Estados Unidos, em criar canais de fornecimento alternativos ao russo confere a Kiev margem de manobra em relação a Moscou, fazendo com que a Ucrânia consiga, por vezes, escapar da força econômica e militar russa. 
A conclusão é a de que a operacionalização da Gazprom por Moscou tem gerado resultados positivos para o país, embora tais resultados não abranjam todos os casos. Ressalte-se, ainda, que as especificidades do mercado do gás - menos flexível que o de petróleo e ainda fortemente dependente do transporte por meio de gasodutos - contribuem para a efetividade dessa política.

Observa-se, porém, que essa política, no caso da Rússia especificamente, possui fundamentos frágeis. A forte dependência deste país das receitas gerados pelo setor de petróleo e gás pode obrigá-lo a retroceder em sua atuação internacional em um cenário de preços baixos, uma vez que problemas de ordem econômica obrigatoriamente pesarão na realização de seus objetivos no cenário internacional. O contexto recente de queda de preços no mercado mundial oferece oportunidade de se verificar se a assertividade da política externa de Putin será mantida. É possível que, em razão da diminuição de receitas oriundas da venda de hidrocarbonetos, as ambições internacionais de Moscou se tornem menos destacadas. 


\section{BIBLIOGRAFIA}

AALTO, P. Modernisation of the Russian Energy Sector: Constraints on Utilising Arctic Offshore Oil Resources. Europe-Asia Studies 68 (1), 2016. p. 38-63

AALTO, P.; WESTPHAL, K. Introduction. In: AALTO, P. (Ed.) The EU-Russian Energy Dialogue: Europe's Future Energy Security. Hampshire: Ashgate, 2008. p. 1-21.

ABELLÁN, L.; FARIZA, I. El apoyo europeo a Ucrania permite zanjar la guerra del gas con Rusia. El País, 31 Oct. 2014. Disponível em: < http://internacional.elpais.com/internacional/2014/10/31/actualidad/1414793573 64409 4.html>. Acesso em: 15 jan. 2017.

ADAM, G. A Rússia e os Países da Comunidade dos Estados Independentes no Início do Século XXI. In: ALVES, A. G. (Ed.). Uma longa transição: vinte anos de transformações na Rússia. Brasília: Ipea, 2011. p. 39-79.

A Rússia como Grande Potência e a Parceria Estratégica com a China. In: ALVES, A. G. (Ed.). O Renascimento de uma Potência: A Rússia no Século XXI.

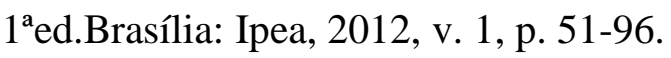

AIZHU, C.; MENG, M. Russia beats Saudi Arabia as China's top crude oil supplier in 2016. Reuters, 23 Jan. 2017. Disponível em: $<$ http://www.reuters.com/article/us-chinaeconomy-trade-crude-idUSKBN1570VJ > . Acesso em: 3 mai. 2017.

AL-FATTAH, S. National Oil Companies: Business Models, Challenges, and Emerging Trends. Saudi Aramco, January, 2013.

ALVES, A. A Rússia Sofre de Doença Holandesa? In: $O$ renascimento de uma potência: a Rússia no Século XXI. Brasília: Ipea, 2012. p. 129-163.

Internacionalização de Empresas Russas. In: Uma longa transição:

vinte anos de transformações na Rússia. Brasília: Ipea, 2011. p. 183-240.

O Sistema Bancário da Rússia entre Duas Crises. In: Uma longa transição: Vinte Anos de Transformações na Rússia. $1^{\mathrm{a}}$ ed. Brasília: Ipea, 2011. p. 241288.

APPLEYARD, D.; FIELD JR., A.; COBB, S. Economia Internacional. $6^{\text {a }}$ ed. Porto Alegre: AMGH Editora, 2010.

ARANTES JR., A. A Passagem do Neoestalinismo ao Capitalismo Liberal na União Soviética e na Europa Oriental. Brasília: Funag, 2015.

BAEV, P. Diversification, Russian-style: Searching for Security of Demand and Transit. In: GODZIMIRSKI, J. (Ed.), Russian Energy in a Changing World: What is the Outlook for the Hydrocarbons Superpower. London: Ashgate, 2013. p 111-130. 
. Russian Energy Policy and Military Power: Putin's Quest for Greatness. Abingdon-New York: Routledge, 2008.

BAHGAT, G. Energy Security: An Interdisciplinary Approach. Hoboken, NJ: Wiley, 2011.

BALMACEDA, M. Politics of Energy Dependence: Ukraine, Belarus, and Lithuania between Domestic Oligarchs and Russian Pressure, 1992-2012. Toronto: University of Toronto Press, 2013.

BARYSCH, K. The EU and Russia: Strategic partners or squabbling neighbours? CER pamphlet, May 2004.

BELYI, A. "Trends of Russia's Gas Sector Regulation", Fourth Annual Conference on Competition and Regulation of Network Industries, Brussels, 25 November 2011.

BILGIN. Mert. Energy security and Russia's gas strategy: The Symbiotic Relationship Between the State and Firms. Communist and Post-Communist Studies, 44, 2011. p. 119-127.

BP. 2016 Energy Outlook, London, London, United Kingdom, 2016.

BP Statistical Review of World Energy, London, United Kingdom, June 2015.

BREUNING, M. Foreign Policy Analysis: A Comparative Introduction. New York: Macmillan, 2007.

BROAD, W. In Taking Crimea, Putin Gains a Sea of Fuel Reserves. The New York Times, New York, 1 May 2014. Disponível em: < https://www.nytimes.com/2014/05/18/world/europe/in-taking-crimea-putin-gains-a-seaof-fuel-reserves.html?_r=0 >. Acesso em: 27 jul. 2014.

BROS, A.; RICHARD, Y. Relação Energética Rússia-União Europeia. Mercator: Fortaleza, v. 10, n. 21, p. 7-31, jan./abr. 2011.

CÂMARA, M. A Política Externa Alemã na República de Berlim: de Gerhard Schröder a Angela Merkel. Brasília: Funag, 2013.

CANTONI, R. Breach of Faith? Italian-Soviet Cold War Trading and ENI's International Oil Scandal. Quaestio Rossica, 2015, p. 180-198.

CARAFANO, J. et al. U.S. Comprehensive Strategy Toward Russia. Special Report \#173 on Russia and Eurasia. The Heritage Foundation. December 9, 2015

CORRELJÉ, A; VAN DER LINDE, C. Energy supply security and geopolitics: A European perspective. Energy Policy, v. 34, n. 5, 2006. p. 532-543

CARTER, J. "Speech at the State of the Union Address 1980". In: Jimmy Carter Library, 23 January, $1980 . \quad$ Disponível em: < 
https://www.jimmycarterlibrary.gov/documents/speeches/su80jec.phtml >. Acesso em 5 mar. 2017.

CASTRONOVO, V. Gianni Agnelli and Enrico Mattei. In: JONES, E.; PASQUINO, G. (Ed.) The Oxford Handbook of Italian Politics. Oxford University Press, 2015,

CIRCULAÇÃO de gás na Europa cai $30 \%$ após corte da Rússia. Folha de S. Paulo, São Paulo, 2 jan. 2006.2 Disponível em: $<$ http://www1.folha.uol.com.br/folha/mundo/ult94u91116.shtml $>$. Acesso em: 29 mar. 2015.

CLAES, D. Cooperation and Conflict in Oil and Gas Markets. In: The Handbook of Global Energy Policy. First Edition. Edited by Andreas Goldthau. John Wiley \& Sons, 2013.

CLOSSON, S. Russia's Key Costumer: Europe. In: PEROVIC, J.; ORTTUNG, R.W.; WENGER, A. (Ed.) Russian Energy Power and Foreign Relations: Implications for conflict and cooperation. London: Routledge, 2009. p. 89-100

COLLIER, D. Understanding Process Tracing. Political Science and Politics 44, 2011. p. $823-830$

CONRADI, P. Who Lost Russia? How the World Entered a New Cold War. London: Oneworld Publications, 2017

COOLEY, A. Great Games, Local Rules: The New Great Power Contest in Central Asia. Oxford University Press, 2012.

Principles in the Pipeline: Managing Transatlantic Values and Interests in Central Asia. International Affairs. v. 84, n. 6. 2008.

COOPER, A. S. The Oil Kings: How the U.S., Iran, and Saudi Arabia Changed the Balance of Power in the Middle East. Oxford: One World, 2011.

CRANDALL, M. The role of Central Asian gas: is it possible to bypass Russia? In: DELLECKER, A.; GOMART, T. (Ed.). Russian Energy Security and Foreign Policy. Abingdon-New York: Routledge, 2011. p. 74-85.

CRUZ, S. Ser ou não ser? Ucrânia, Rússia e os dilemas da Política Externa Alemã. Carta Internacional (USP), v. 8, p. 1, 2013. p. 58-80.

DAEHNHARDT, P.; FREIRE, M. R. Introdução. In: A Política Externa Russa no Espaço Euro-Atlântico: dinâmicas de cooperação e competição num espaço alargado. Coimbra: Imprensa da Universidade de Coimbra: 2014. p. 11-28

DONALDSON, R.; NOGEE, J. The Foreign Policy of Russia: changing systems, enduring interests. New York: M. E. Sharp, 2005. 
DUTKIEVWICZ, P. Missing in Translation: Re-conceptualizing Russia's Development State. In: DUTKIEVWICZ, P.; TRENIN, D. (Ed.) The Challenges of Transformation. New York: New York University Press, 2011. p. 9-40.

EHRSTEDT, S.; VAHTRA, P. Russian Energy Investments in Europe. Turku, Finland: Eletronic Publicatinos of Pan-European Institute, 2008. Disponível em: < https://www.utu.fi/fi/yksikot/tse/yksikot/PEI/raportit-jatietopaketit/Documents/Ehrstedt_Vahtra_42008.pdf >. Acesso em: 27 jul. 2014.

ENERGY CHARTER. Putting a Price on Energy: International Pricing Mechanisms for Oil and Gas, Brussels: Energy Charter Secretariat, 2007.

ENERGY CHARTER TREATY (ECT), 1994. Disponível em: < http://www.energycharter.org/process/energy-charter-treaty-1994/energy-chartertreaty/>. Acesso em: 25 jul. 2015.

ENTENDA a crise do gás entre Ucrânia e Rússia. BBC Brasil, Brasília, 2 jan. 2006. Disponível em: $<$ http://www.bbc.com/portuguese/reporterbbc/story/2006/01/060102 ucraniagasqa.shtm 1 >. Acesso em: 23 mar. 2015.

ESMAP (ENERGY SECTOR MANAGEMENT ASSISTANCE PROGRAMME). 'Investing in Oil in the Middle East and North Africa: Institutions, Incentives and National Oil Companies.' ESMAP Report No. 40405-MNA. World Bank, Washington, DC, 2007.

EUROPEAN COMMIISSION. A European Strategy for Sustainable, Competitive and Secure Energy, Green Paper, Brussels, 2006.

Communication to the European Parliament, the Council, the European Economic and Social Committee and the Committee of the Regions, European Commission, COM (2010) 639 final, Brussels, 2010.

FATTOUH, B. OPEC Pricing Power: The Need for a New Perspective. Oxford: Institute for Energy Studies, 2007.

FERNANDES, E; SILVEIRA, J. A Reforma do Setor Petrolífero na América Latina: Argentina, México e Venezuela. Nota Técnica. Brasília, ANP, 1999.

FERNANDES, S. Rússia e União Europeia: dois gigantes em um continente. In: FREIRE, M. R.; DAEHNHARDT, P. (Ed.). A Política Externa Russa no Espaço EuroAtlântico: dinâmicas de cooperação e competição num espaço alargado. Coimbra: Imprensa da Universidade de Coimbra: 2014. p. 199-223.

FERRARO Jr., V. O GUAM, a Rússia e o Ocidente. In: SEGRILLO, A.; PENNAFORTE, C. (Ed.) A Ásia no Século XXI: olhares brasileiros. Rio de Janeiro: Cenegri, 2011. p. 2596.

FINON, D.; LOCATELLI, C. Russian and European Gas Interdependence: Could Contractual Trade Channel Geopolitics? Energy Policy, 36, 2008. p. 423-442. 
FRANZA, L. From South Stream to Turk Stream: Prospects for Rerouting Options and Flows of Russian Gas to Parts of Europe and Turkey'. Clingendael International Energy Program (CIEP). The Hague: 2015.

FREIRE, M. R. A Evolução da Política Externa da Rússia. In: FREIRE, M. R.; DAEHNHARDT, P. (Ed.). A Política Externa Russa no Espaço Euro-Atlântico: dinâmicas de cooperação e competição num espaço alargado. Coimbra: Imprensa da Universidade de Coimbra: 2014. p. 29-56

FREIRE, M. R.; DAEHNHARDT, P. As relações entre a Alemanha e a Rússia: duas políticas externas em transição. Relações Internacionais, n. 32, 2011. p. 171-196.

FREITAS, W; JABBOUR, C. Utilizando estudo de caso(s) como estratégia de pesquisa qualitativa: boas práticas e sugestões. Estudo \& Debate, Lajeado, v. 18, n. 2, p. 7-22, 2011.

FRIEDMAN, T. The First Law of Petropolitics. Foreign Policy, 16 Oct. 2009. Disponível em: $<$ http://foreignpolicy.com/2009/10/16/the-first-law-of-petropolitics/ > . Acesso em: 9 nov. 2015.

FROMKIN, D. A Peace To End All Peace: The Fall Of The Ottoman Empire And The Creation Of The Modern Middle East. New York: Henry Holt \& Co, 1989.

FUSER, I. O petróleo e o envolvimento militar dos Estados Unidos no Golfo Pérsico (1945-2003). 2005. 330f. Dissertação (Mestrado em Relações Internacionais). San Tiago Dantas (PUC-SP/Unesp/Unicamp), São Paulo, 2009.

Os recursos energéticos e as teorias das relações internacionais. In: HAGE, J. A. (Ed.). A energia, a política internacional e o Brasil. São Paulo: Instituto Memória, 2008.

GABUEV, A. A "Soft Alliance"? Russia-China Relations After The Ukraine Crisis. European Council on Foreign Relations Policy Brief, CFR/126, February 2015.

. Friends With Benefits? Russian-Chinese Relations After the Ukraine Crisis.

Carnegie Moscow Center, 29 Jun. 2016. Disponível: < http://carnegie.ru/2016/06/29/friends-with-benefits-russian-chinese-relations-afterukraine-crisis-pub-63953 >. Acesso em: 15 jun. 2016.

GAIDAR, Y. Collapse of an empire: lessons for modern Russia. Washington: Brookings Institution Press, 2007.

GAZPROM. 40 Years in the German Market. Disponível em: < http://www.gazprom.com/about/history/events/germany40/>. Acesso em: 10 jun. 2016.

About Gazprom. Disponível em: < http://www.gazprom.com/about/>. Acesso em: 30 mai. 2016. 
Delivery statistics. Disponível em:

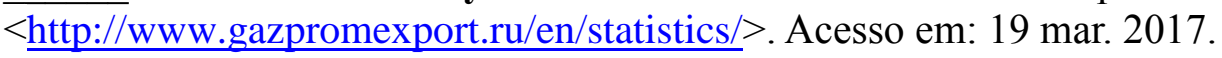

Questions and answers. Disponível em:

$\overline{<\mathrm{http}: / /}$ www.gazpromquestions.ru/en/about/>. Acesso em: 30 mai. 2016.

GAZPROM becomes $100 \%$ owner of abandoned South Stream gas pipeline. Russia Today (RT), 30 Dec. 2014. Disponível em: <https://www.rt.com/business/218635gazprom-owner-south-stream/>. Acesso em: 22 nov. 2015.

GEBAUER, M. et al. Germany Considers Easing of Russia Sanctions. Der Spiegel, 30 May 2016. Disponível em: <http://www.spiegel.de/international/europe/germanyconsidering-an-easing-of-russia-sanctions-a-1094585.html> . Acesso em: 5 set. 2017.

GECF. GECF Overview. Disponível em: https://www.gecf.org/about/overview.aspx. Acesso em: 10 jun. 2016.

GENTÉ, R. Jogos de influência em uma Ásia Central desunida. Le Monde Diplomatique Brasil, 1 dez. 2014. Disponível em: < http://www.diplomatique.org.br/artigo.php?id=1778> Acesso em: 16 fev. 2015.

GERRING, J. What is a case study and what is it good for? American Political Science Review, v. 98, n. 2, 2004. p. 341-354.

GHALEB, A. Natural Gas as an Instrument of Russian State Power. The Letort Papers. Carlisle, PA: Strategic Studies Institute, U.S. Army War College, 2011.

GHOLZ, E.; PRESS, D. Protecting "The Prize": Oil and the U.S. National Interest. Security Studies, 19: 3, 2010. p. 453-485.

GIBNEY, J. Sanction Russia? Reagan Tried It With No Luck. Bloomberg, 17 Mar. 2014. Disponível em: $<\underline{\text { https://www.bloomberg.com/view/articles/2014-03-17/sanction-russia- }}$ we-ve-tried-this-before $>$. Acesso em: 18 mar. 2015.

GIELOW, I. Desabitado, oriente russo impõe desafios para Putin. Folha de S. Paulo, São Paulo, 9 abr. 2017. Disponível em: <http://www1.folha.uol.com.br/mundo/2017/04/1873973-desabitado-oriente-russoimpoe-desafios-para-putin.shtml>. Acesso em: 10 abr. 2017.

GIL, A. C. Métodos e Técnicas de Pesquisa Social. 6 ed. São Paulo: Atlas, 2008.

GINSBERG, J. Reassessing the Jackson-Vanik Amendment. Council on Foreign Relations. 2 July 2009. Disponível em: 〈http://www.cfr.org/trade/reassessing-jacksonvanik-amendment/p19734 > Acesso em: 8 fev. 2017.

GLASER, C.; KELANIC, R. Introduction. In: Crude Strategy: Rethinking the US Military Commitment to Defend Persian Gulf Oil. Washington: Georgetown University Press, 2016. 
GOLDMAN, M. Putin, power and the new Russia: Petrostate. New York: Oxford University Press, 2008.

GOLDSTEIN, A. New Multinationals from Emerging Asia: The Case of National Oil Companies. Asian Development Review, v. 26, n. 2, 2009. p. 25-56.

GOldthaU, A. Resurgent Russia? Rethinking Energy Inc. Policy Review, n. 147, March 2008.

Rhetoric versus reality: Russian threats to European energy supply. Energy Policy, Elsevier 36, 2008. p. 686-692.

GOLDTHAU, A.; SOVACOOL, B. The uniqueness of the energy security, justice, and governance problem. Energy Policy, Elsevier 41, p. 232-240, Nov. 2012.

GOLDTHAU, A.; WITTE, J. M. Back to the future or forward to the past? Strengthening markets and rules for effective global energy governance. International Affairs 85: 2, 2010. p. 373-390.

The Role of Rules and Institutions in Global Energy: An Introduction. In:

Global Energy Governance: the new rules of the game. Brookings Institution Press and Global Public Policy Institute, Berlin: 2010. p. 1-25.

GÖKAY, B. History of Oil Development in the Caspian Basin. In: ARAS, B.; CROISSANT, M. (Ed.). Oil and Geopolitics in the Caspian Sea Region. Westport: Praeger, 1999. p. 3-19

GROMADZKI, G.; KONONCZUK; W. Energy Game: Ukraine, Moldova and Belarus between the EU and Russia, Warsaw: Stefan Batory Foundation, 2007.

GUSTAFSON, T. Wheel of Fortune: the battle for oil and power in Russia. Cambridge: Belknap Press of Harvard University Press, 2012.

. Putin's Petroleum Problem. Foreign Affairs, 24 Oct. 2012. Disponível em: < http://www.foreignaffairs.com/articles/138363/thane-gustafson/putins-petroleumproblem >. Acesso em: 23 mar. 2015.

HAFEZI, P. Russia, Iran, Qatar agree to form "big gas troika". Reuters, 21 Oct. 2008. Disponível em: $\quad<$ http://www.reuters.com/article/iran-gas-opecidUSDAH12925720081021.> Acesso em: 11 jun. 2016.

HASHIM. M. Power-loss or Power-Transition? Assessing the limits of using the energy sector in reviving Russia's geopolitical stature. Communist and Post-Communist Studies, 43, 2010. p. 263-274.

HARDING, L. The richer they come...The Guardian, 2 Jul. 2007. Disponível em: https://www.theguardian.com/world/2007/jul/02/russia.lukeharding1Acesso em: 20 dez. 2016. 
HEINRICH, A. Introduction: Export Pipelines in Eurasia. In: HEINRICH, A.; PLEINES, H. (Ed.). Export pipelines from the CIS region: Geopolitics, securitization, and political decision-making. Research Centre for East European Studies at the University of Bremen. Stuttgart: 2014. p. 1-73.

HELÉN, H. "The EU`s security dilemma with Russia." University of Leeds POLIS journal (2010): 1-40. Disponível em: http://www.polis.leeds.ac.uk/assets/files/students/student-journal/ma-winter- 10/helene.pdf. Acesso em 30 de dezembro 2015.

HELLFELD, M. 1990: Tratado Dois-Mais-Quatro definiu as condições para a reunificação alemã. Deutsche Welle, 12 set. 2016. Disponível em: < http://www.dw.com/pt-br/1990-tratado-dois-mais-quatro-definiu-ascondi\%C3\%A7\%C3\%B5es-para-a-reunifica\%C3\%A7\%C3\%A3o-alem\%C3\%A3/a5998104 >. Acesso em: 16 ago. 2017.

HENDRICKSON, G. B. The Future of NATO-Russian Relations: Or, How to Dance with a Bear and Not Get Mauled, Washington, D.C.: The Atlantic Council of the United States, 2005

HILL, F. Energy Empire: Oil, Gas and Russia’s Revival. London: The Foreign Policy Centre, set. 2004.

HILL, F.; LO, B. Putin's pivot. Foreign Affairs, 31 Jul. 2013. $<$ https://www.foreignaffairs.com/articles/russian-federation/2013-07-31/putins-pivot $>$.

Acesso em: 16 fev. 2015.

HÖGSELIUS, P. Red Gas: Russia and the Origins of European Energy Dependence. New York: Palgrave Macmillan, 2013.

HOYOS, C. The new Seven Sisters: oil and gas giants dwarf western rivals. The Financial Times, 12 Mar. 2007. Disponível em: $<\underline{\text { http: } / / w w w . f t . c o m / c m s / s / 2 / 471 a e 1 b 8-~}$ d001-11db-94cb-000b5df10621.html\#axzz3UlkAnTp9>. Acesso em: 18 mar. 2015.

HULTS, D. Petróleos de Venezuela, S.A. (PDVSA): From Independence To Subservience. In: VICTOR, D. G., HULTS, D., THURBER, M. C. (Ed.), Oil and Governance: State-owned Enterprises and the World Energy Supply. Cambridge University Press, Cambridge, 2012. p. 418-478.

HUDSON, V. Foreign Policy Analysis: Actor - Specific Theory and the Ground of International Relations, Foreign Policy Analysis, vol. 1, issue 1, 2005. p. 1-30.

IKENBERRY, J. Market Solutions for State Problems: the international and domestic politics of American oil decontrol. In: IKENBERRY, J.; LAKE, D.; MASTANDUNO, M. (Ed.). The State and American Foreign Policy, Ithaca: Cornell University Press.

IMONTI, F. How Vladimir Putin and Russia Hope to Win Big-In Syria. CNBC, 26 Feb. 2013. < http://www.cnbc.com/id/100496808>. Acesso em: 19 mar. 2015. 
INTERNATIONAL ENERGY AGENCY (IEA). Key World Energy Statistics. Paris: International Energy Agency, 2014.

Key World Energy Statistics. Paris: International Energy Agency, 2015.

Member Countries. Disponível em:

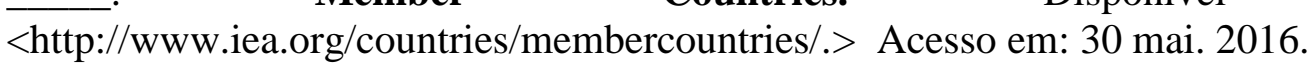

INTERNATIONAL MONETARY FUND (IMF). World Economic Outlook: Too Slow for Too Long. Washington: International Monetary Fund, April 2016.

JAFFE, A. M.; SOLIGO, R. Militarization of Energy: Geopolitical Threats to the Global Energy System. James A. Baker Institute for Public Policy, Rice University, Houston, TX. May, 2008.

JAFFE, A. M.; WILSON, W.; SOLIGO, R. The International Oil Companies. James A. Baker Institute for Public Policy, Rice University, Houston, TX: 2007.

JODI. Gas Exporting Countries Forum (GECF). Disponível em: https://www.jodidata.org/about-jodi/partners/gecf.aspx. Acesso em: 10 jun. 2016.

KELANIC, R. Oil Security and Conventional War: Lessons From a China-Taiwan Air Scenario. Council on Foreign Relations, October 2013.

The Petroleum Paradox: Oil, Coercive Vulnerability, and Great Power Behavior. Security Studies 25:2. Council on Foreign Relations, 2016. p. 181-213.

KEOHANE, R. After Hegenomy: Cooperation and Discord in the World Political Economy. Princenton: Princenton University Press, 1984.

KEOHANE, R.; NYE, J. Power and Interdependence: World politics in transition. 4th ed. Longman Classics in Political Science, 2012

KHANNA, P. The Second World: Empires and Influence in the New Global Order. New York: Random House, 2008.

KLARE, M. Blood and Oil: The Dangers and Consequences of America's Growing Dependency on Imported Petroleum, New York: Henry Holt, 2005. $\overline{\text { Holt, } 2002 .}$

Resource Wars: The New Landscape Of Global Conflict, New York: Henry

KONOPLYANIK, A. Energy Security and the Development of International Energy Markets. In: BARTON, B., REDGWELL, C., RONNE, A., ZILLMAN, D. N. (Ed.), Energy security: Managing Risk in a Dynamic Legal and Regulatory Environment. International Bar Association/Oxford University Press, 2004. p. 47-84.

KOTKIN, S. Armageddon Averted: The Soviet Collapse, 1970-2000. Oxford: Oxford University Press, 2008. 
KRASNER, S. Defending the National Interest: Raw Materials Investments and U.S. Foreign Policy. Princeton: Princeton University Press, 1978.

KROPATCHEVA, E. EC's Anti-Trust Inquiry into Gazprom's Practices: Its Significance and Meaning for Gazprom's Role in the EU Market. Russian Analytical Digest, n. 174, October 2015.

KUHRT, N. Russian Foreign Policy. In: GILL, G.; YOUNG, J. (Ed.) Routledge Handbook of Russian Politics and Society. London-New York: Routledge, 2015. p. 421-431.

LEIS, J.; MCCREEY, J.; GAY, J. C. National Oil Companies Reshape The Playing Field. Bain Brief. October, 2012.

LESAGE, D.; VAN DE GRAAF, T.; WESTPHAL, K. Global Energy Governance in a Multipolar World, Farhham: Ashgate: 2010.

LIGHT, M. Russian Foreign Policy. In: WHITE, S.; SAKWA, R. Developments in Russian Politics. Durham: Duke University Press, 2010. p. 226-243.

LO, B. Axis of Convenience: Moscow, Beijing, and the new geopolitics. London: Brookings Institution Press and Chatham House, 2008.

LUKYANOV, F. Future Isn't Bright for EU-Russian Relationship. The Moscow Times. 11 Dec. 2014. Disponível em: $<\underline{\mathrm{http}}$ ://www.themoscowtimes.com/opinion/article/futureisn-t-bright-for-eu-russian-relationship/513145.html> Acesso em 13 mar. 2015.

LUONG, P.; SIERRA, J. The Domestic Political Conditions for International Economic Expansion: Lessons From Latin American National Oil Companies. Comparative Political Studies. v. 48, n. 14, p. 2010-2043. 2015.

MANKOFF, J. Eurasian Energy Security. Council on Foreign Relations Special Report, New York, n. 43, February 2009.

Russia's Latest Land Grab. Foreign Affairs, 17 Apr. 2014. Disponível em: < $\overline{\mathrm{https}: / / \mathrm{www} . f o r e i g n a f f a i r s . c o m / a r t i c l e s / r u s s i a n-f e d e r a t i o n / 2014-04-17 / r u s s i a s-l a t e s t-~}$ $\underline{\text { land-grab }}>$ Acesso em 15 out. 2016.

Russian Foreign Policy: The Return of Great Power Politics. $2^{\text {nd }}$ ed. Lanham, MD: Rowman \& Littlefield, 2011.

The Calculations of Russia's Neighbors. Center for Strategic and International Studies. Global Forecast, 2015.

Why Russia and Turkey Fight. Foreign Affairs, 15 Jun. 2016. Disponível em: $<$ https://www.foreignaffairs.com/articles/turkey/2016-02-24/why-russia-and-turkeyfight $>$ Acesso em 15 out. 2016.

MARCEL, V. Oil Titans: National Oil Companies in the Middle East. London: Royal Institute of International Affairs, 2006. 
MARKOV, S. Rússia na mais importante etapa política das eleições parlamentares de 2007 e presidenciais de 2008. In: Rússia. Brasília: Fundação Alexandre de Gusmão, 2007.

MAZAT, N. A Rússia dos anos 90: crônica de um desastre anunciado: vulnerabilidade, cooperação e conflito. 26 fev. 2008. Crítica Econômica. Disponível em: <https://criticaeconomica.wordpress.com/2008/02/26/a-russia-dos-anos-90-cronica-deum-desastre-anunciado/>. Acesso em: 25 set. 2014

MAZAT, N.; SERRANO, F. A geopolítica da Federação Russa em relação aos Estados Unidos e à Europa: vulnerabilidade, cooperação e conflito. In: ALVES, A. G. (Ed.). O renascimento de uma potência: a Rússia no Século XXI. Brasília: Ipea, 2012. p. 9-50.

MCPHERSON, C. National Oil Companies: Ensuring Benefits and Avoiding Systemic Risks. In: GOLDTHAU, A. (Ed.) The Handbook of Global Energy Policy. John Wiley \& Sons, Ltd., 2013.

MEARSHEIMER. J. Why the Ukraine crisis is the West's fault. Foreign Affairs, 18 Oct. 2014. Disponível em: <http://www.foreignaffairs.com/articles/141769/john-j.mearsheimer/why-the-ukraine-crisis-is-the-wests-fault > Acesso em: 12 mar 2015.

MEDEIROS, C. A Economia Política da Transição na Rússia. In: ALVES, A. G. (Ed.). Uma Longa Transição: vinte anos de transformações na Rússia. Brasília: Ipea, 2011. p. 13-39.

Recursos Naturais, Nacionalismo e Estratégias de Desenvolvimento. Revista Oikos, Rio de Janeiro, v. 12, n. 2, 2013. p. 143-167.

METAIS, R. Ensuring Energy Security in Europe: The EU between a Market-based and a Geopolitical Approach. College of Europe: EU Diplomacy Paper 03 / 2013.

MITCHELL, J.; MARCEL, V.; MITCHELL, B. What Next for the Oil and Gas Industry? London: Chatham House. October 2012.

MOLCHANOV, M. Energy Security and the Revival of Geopolitics: The Russian Case. In: HENSEL, K. (Ed.) New Security Frontiers: Critical Energy and the Resource Challenge. Farhham: Ashgate, 2013. p. 9-30.

Eurasian Regionalism and Russian Foreign Policy. London: Ashgate, 2015.

MONALDI, F. Is Resource Nationalism Fading in Latin America? The Case of the Oil Industry. Issue Brief no. 09.03.14. Rice University's Baker Institute for Public Policy, Houston, Texas.

MOVCHAN, A. Boomerang Sanctions: Russia Punishes Turkey. Carnegie Moscow Center, 9 Dec. 2015.2 Disponível: $<$ http://carnegie.ru/commentary/2015/12/09/boomerang-sanctions-russia-punishesturkey/imwk>. Acesso em: 15 jun. 2016. 
MOTTA M.; RUTA M. Do We Need National or European Champions?: Mergers and National Champions. CESifo Conference (Munich, Germany) November 2007, PP1617.

NAKANO, J.; CHOW, E. The West Siberia gas supply deal on the horizon for Russia and China: is a friend in need a friend indeed? Center for Strategic \& International Studies. 24 nov. 2014. Disponível em: < https://www.csis.org/analysis/west-siberia-gas-supplydeal-horizon-russia-and-china-friend-need-friend-indeed > . Acesso em: 16 fev. 2015.

NASCIMENTO, F. A Limitação à Cooperação Securitária Sino-Russa na Ásia Central Devido ao não Gerenciamento Conjunto do Fluxo Local de Hidrocarbonetos por Moscou e Pequim. 2015, 183f. Tese de Doutorado. IRI/USP, 2015.

Federação Russa e Otan: uma análise das políticas de Moscou em relação à aliança ocidental. 2008, 141 f. Dissertação (Mestrado em Relações Internacionais). San Tiago Dantas (PUC-SP/Unesp/Unicamp), São Paulo, 2008.

NICHOL, J. Russian political, economic, and security issues and U.S. interests. Congressional Research Service. 7-5700, 31 March 2014.

NIXON, R. "Address to the Nation About Policies to Deal With the Energy Shortages". In: The American Presidency Project, 7 November, 1973. Disponível em: < http://www.presidency.ucsb.edu/ws/?pid=4034> . Acesso em 9 mar. 2017.

NOCEDA, M. A Oportunidade do Gás. El País, 5 abr. 2014. Disponível em: $<$ http://brasil.elpais.com/brasil/2014/04/04/economia/1396639403 001089.html >.

Acesso em: 28 abr. 2014.

OFFICIAL JOURNAL OF THE EUROPEAN UNION. Directive 2003/55/EC of the European Parliament and of the Council, 15 July 2003.

OPDHAL, I. Gazprom in the Post-Soviet Region: Shrinking Markets, Politicised Relations. Russian Analytical Digest n. 174, 26 October 2015

ORTEGA, F. Cores da Mudança? As Revoluções Coloridas e seus reflexos em política externa. 2009. 139f. Dissertação (Mestrado em Relações Internacionais). San Tiago Dantas (PUC-SP/Unesp/Unicamp), São Paulo, 2009.

ORTTUNG, R. Energy and state-society relations: socio-political aspects of Russia's energy wealth. In: PEROVIC, J.; ORTTUNG, R.; WENGER, A. (Ed.) Russian Energy Power and Foreign Relations: Implications for conflict and cooperation. London: Routledge, 2009. p. 51-70.

ORTTUNG, R.; TISSOT, R. Can Brazil be a Model of Development for Russia? PONARS Eurasia Policy Memo n. 126, 2010.

PAILLARD, C. A. Gazprom, the Fastest Way to Energy Suicide. Russie Nei Visions. No. 17 IFRI Russia/NIS Center, Paris: Março, 2007. 
PANIBRATOV, A. Russian Multinationals: From Regional Supremacy to Global Lead. New York: Routledge, 2012.

PAYING the piper. The Economist, 4 Jan. 2014. Disponível em: <http://www.economist.com/news/business/21592639-european-efforts-reduce-russianstate-owned-companys-sway-over-gas-prices-have-been. > Acesso em: 16 jun. 2016.

PEREIRA, T. L. Federação Russa: A Diarquia Vladimir Putin (2000-2008) \& Dmitry Medvedev (2008-2012). 2015. 177f. Dissertação (Mestrado em Estudos Estratégicos da Defesa e Segurança) Instituto de Estudos Estratégicos, Universidade Federal Fluminense, Niterói, 2015.

PEROVIC, J. The Soviet Union's Rise as an International Energy Power: A Short History. In: PEROVIC, J (Ed.) Cold War Energy: A Transnational History of Soviet Oil and Gas. New York: Palgrave Macmillan, 2016, p. 371-389.

PICK, L. EU-Russia Energy Relations: A Critical Analysis. University of Leeds: POLIS Journal, v. 7, 2012.

PIMENTEL, F. O Fim da Era do Petróleo e a Mudança do Paradigma Energético Mundial: perspectivas e desafios para a atuação brasileira. Brasília: Funag, 2011.

POLETTO, R. Geórgia: Os Sintomas do Cáucaso entre a Rússia e o Ocidente. Meridiano 47, ago. 2007. p. 10-13.

POMERANZ, L. Rússia: economia e sociedade. In: Rússia. Brasília: Fundação Alexandre de Gusmão, 2007. p. 101-116.

POMERANZ, W. Russian Protectionism and the Strategic Sectors Law. American University International Law Review, n. 25, 2010. p. 214-217.

POPOV, V. Redux Russia. New Left Review, n. 44, 2007.

POUSSENKOVA, N. The Global Expansion of Russia's Energy Giants. Journal of International Affairs, Spring/Summer, v. 63, n. 2, 2010.

PRIMAKOV, Y. Russian Crossroads: Towards The New Millennium. Yale University Press. New Haven/London: 2004.

PROEDROU, F. EU Energy Security in the Gas Sector: Evolving Dynamics, Policy Dilemmas and Prospects. Farnham: Ashgate, 2012.

PUTIN, V. "Speech at the $43^{\text {rd }}$ Munich Conference on Security". In: Munich Conference On Security Policy, 10 Feb. 2007. Disponível em: < http://en.kremlin.ru/events/president/transcripts/24034> . Acesso em 1 mar. 2017.

QUINTELLA, T. M. Prefácio. In: (Ed.) Brasil - Rússia: fortalecimento de uma parceria. Brasília: Fundação Alexandre de Gusmão, 2005 p. 9-17. 
REIS FILHO, D. A. Rússia - Política e Estratégia. In: Rússia. Brasília: Fundação Alexandre de Gusmão, 2007, p. 51-77.

RENZ, B. The Russian Power Ministries and Security Services. In: GILL, G.; YOUNG, J. (Ed.) Routledge Handbook of Russian Politics and Society. London-New York: Routledge, 2015, p. 209-219.

ROBERTS, J. After the War. In: DELLECKER, A.; GOMART, T. (Ed.). Russian Energy Security and Foreign Policy. Abingdon-New York: Routledge, 2011, p. 170-187.

ROCCO, A. O mercado energético da União Europeia e as "campeãs nacionais": uma ameaça para segurança energética? I Seminário Internacional de Ciência Política, UFRGS, Porto Alegre, Setembro de 2015.

RUTLAND, P. Can Russia Escape the Oil Curse? In: The National Bureau of Asian Research (NBR): Russia's Political Economy: Trends and Implications. Washington: April 2008.

Introduction: The Tragedy of Crimea. In: Transitions Online (Ed.). Crimea: The Anatomy of Crisis. Prague: Transitions Online, Jan., 2015.

SAKWA, R. “Can Putinism Solve Its Contradictions?” Open Democracy, 27 dec. 2013. Disponível em: $<$ https://www.opendemocracy.net/od-russia/richard-sakwa/can-putinismsolve-its-contradictions $>$ Acesso em 23 jun. 2016.

. Frontline Ukraine: Crisis in the Borderlands. London: I.B. Tauris, 2015

. Putin, Russia's Choice. 2. Ed. London \& New York: Rutledge, 2008.

2014.

Putin and the Oligarch: The Khodorkovsky-Yukos Affair. London: I.B. Tauris,

SCHUTTE, G. Economia Política de petróleo e gás: a experiência russa. In: ALVES, A. G. (Ed.). Uma longa transição: vinte anos de transformações na Rússia. Brasília: Ipea, 2011, p. 82-136.

SEGRILLO, A. A diarquia Putin-Mevedev: dimensões da política interna e da política externa. In: ALVES, A. G. (Ed.). Uma longa transição: vinte anos de transformações na Rússia. Brasília: Ipea, 2011, p. 137-153.

A questão da democracia na Rússia pós-soviética. In: ALVES, A. G. (Ed.). O renascimento de uma potência: a Rússia no Século XXI. Brasília: Ipea, 2012, p. 97128.

As Transformações URSS-Rússia: reforma ou revolução? In: QUINTELLA, M. T. (Ed.) Brasil - Rússia: fortalecimento de uma parceria. Brasília: Funag, 2005, p. 313332. 
SHLEIFER, A.; TREISMAN, D. Why Moscow Says No. Foreign Affairs, 1 Jan. 2011. Disponível em: <http://www.foreignaffairs.com/articles/67044/andrei-shleifer-anddaniel-treisman/why-moscow-says-no>. Acesso em: 2 mar. 2015.

SHUVALOV, I. Apresentação do assessor do presidente da federação da Rússia. In: QUINTELLA, M. T. (Ed.). Brasil - Rússia: fortalecimento de uma parceria. Brasília: Funag, 2005. p. 29-55.

SKALAMERA, M. "China can't solve Russia's energy technology trap". The Diplomat. 13 fev. 2015. Disponível em: <http://thediplomat.com/2015/02/china-cannot-solverussias-energy-technology-trap/>. Acesso em 18 fev. 2015.

SMIL, V. Natural Gas: Fuel for the 21st Century. John Wiley \& Sons, United Kingdom, 2015.

STARODUBROVSKAIA, I. Reformas da economia russa no pós-comunismo: os resultados e as perspectivas. In: QUINTELLA, M. T. (Ed.) Brasil - Rússia: fortalecimento de uma parceria. Brasília: Fundação Alexandre de Gusmão, 2005. p. 193238.

STENGEN, K. Deconstructing the “energy weapon'”: Russia's threat to Europe as case study. Energy Policy, 39, 2011, p. 6505-6513.

STENT, A. From Embargo to Ostpolitik: The Political Economy of West GermanSoviet Relations, 1955-1980. Cambridge University Press, 2013.

Russia and Germany Reborn: Unification, The Soviet Collapse, And The New Europe. Princeton: Princeton University Press, 1999.

The U.S. Sanctions Bill Is a Win for Russia. The National Interest, 28 Jul. 2017. Disponível em: $<$ http://nationalinterest.org/feature/the-us-sanctions-bill-win-russia21718? page $=$ show $>$ Acesso em 19 ago. 2017.

STEPANOVA, K. Russia. In: BELLAMY, A.; DUNNE, T. (Ed.) The Oxford Handbook of the Responsibility to Protect. Oxford University Press, 2016, p. 409-428

STERN, J. The Future of Russian Gas and Gazprom. Oxford: Oxford University Press, 2005 .

The Russian-Ukrainian Gas Crisis of January 2006. London: Oxford Institute for Energy Studies (OIES), 2006.

STERN, J.; PIRANI, S.; YAFIMAVA, K. Does the cancellation of South Stream signal a fundamental reorientation of Russian gas export policy? Oxford Institute for Energy Studies (OIES), Janeiro, 2015.

STEVEnS, P. A Methodology for Assessing the Performance of National Oil Companies. Background Paper, The International Bank for Reconstruction and Development, World Bank, Washington, D.C. 2008. 
International Oil Companies: The Death of the Old Business Model. London: Chatham House, 2016.

National Oil Companies: Good or Bad? A Literature Survey. World Bank Workshop. Washington, DC, 2003.

The History of Oil. Polinares (Working Paper 5). September 2010.

STIGLITZ, J. Globalization and its discontents. New York: W. W. Norton \& Company: New York \& London, 2003.

TASS. Infographics: Russia's natural gas export to Europe in 2013. Disponível em: < http://tass.ru/en/infographics/7269 >. Acesso em: 15 fev. 2015.

- Infographics: Gas Pipelines to Europe by 2018. Disponível em: < http://tass.ru/en/infographics/7275 >. Acesso em: 15 fev. 2015.

THE WORLD BANK. GDP growth (annual \%). Disponível em: < http://data.worldbank.org/indicator/NY.GDP.MKTP.KD.ZG?end=2015\&locations=RU

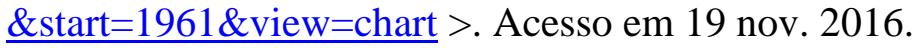

TORDO, S.; TRACY, B. S.; ARFAA, N. National Oil Companies and Value Creation. World Bank Working Paper 218. Washington, DC: The World Bank, 2014.

TREISMAN, D. "Loans for Shares" Revisited. Post-Soviet Affairs, 26, 3, JulySeptember, 2010. p 207-27 Press, 2011.

The Return: Russia's journey from Gorbachev to Medvedev. New York: Free

Watching Putin in Moscow. Foreign Affairs, 5 Mar. 2014. Disponível em: < https://www.foreignaffairs.com/articles/russian-federation/2014-03-05/watching-putinmoscow>. Acesso em: 20 fev. 2015.

TRENIN, D. From a Greater Europe to a Greater Asia? Carnegie Moscow Center. 26 Feb. 2015. Disponível em: <http://carnegie.ru/2015/02/26/from-greater-europe-togreater-asia/i327> Acesso em: 17 mar. 2015

TSYGANKOV, A. If not by tanks, then by banks? The role of soft power in Putin's foreign policy. Europe-Asia Studies, v. 58, n. 7. Nov. 2006.

Russia's Foreign Policy. In: HERSPRING, D. R.; WEGREN, S. K. After Putin's Russia: Past Imperfect, Future Uncertain. New York: Rowman \& Littlefield Publishers, 2009.

Russia's Foreign Policy: Change and Continuity in National Identity. Plymouth: Rowman \& Littlefield Publishers, 2016.

$\begin{array}{cccr}\text { Times. } & \text { Why Western Sanctions Won't Make Putin Change His Strategy The Moscow } \\ 27 & \text { abr. } & 2014 . & \text { Disponível }\end{array}$ 
$<\underline{\text { http://www.themoscowtimes.com/opinion/article/ukraine-is-putin-s-last- }}$

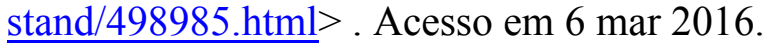

TURQUIA confirma ter parado de receber gás que passa por Ucrânia. Folha de S. Paulo, São Paulo, 6 jan. 2009. Disponível em: < http://www1.folha.uol.com.br/mercado/2009/01/486578-turquia-confirma-ter-paradode-receber-gas-que-passa-por-ucrania.shtml > . Acesso em: 14 jan. 2017.

U.S. ENERGY INFORMATION ADMINISTRATION (EIA). 16\% of natural gas consumed in Europe flows through Ukraine. Today in Energy. 14 Mar. 2014. Disponível $\mathrm{em}:<$ https://www.eia.gov/todayinenergy/detail.php?id=15411>. Acesso em $13 \mathrm{fev}$. 2015.

China is now the world's largest net importer of petroleum and other liquid fuels. $\overline{\text { Today }}$ in Energy. 24 Mar. 2014. Disponível em: < https://www.eia.gov/todayinenergy/detail.php?id=15531>. Acesso em 13 fev. 2015.

Country Analysis Note: Ukraine. Disponível em: < https://www.eia.gov/beta/international/analysis.cfm?iso=UKR $>$. Acesso em: $13 \mathrm{fev}$. 2015.

. Country Analysis Note: Turkmenistan. Disponível em: < https://www.eia.gov/beta/international/country.cfm?iso=TKM $>$. Acesso em: 13 fev. 2015.

Cushing, OK WTI Spot Price FOB (Dollars per Barrel). Disponível em: <

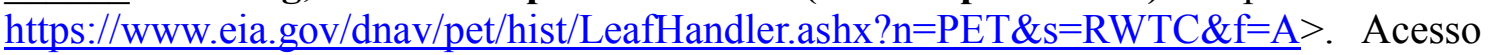
em: 19 nov. 2016.

International energy data and analysis: Russia. Washington, 28 jul. 2015.

Europe Brent Spot Price FOB (Dollars per Barrel). Disponível em: < https://www.eia.gov/dnav/pet/hist/LeafHandler.ashx?n=PET\&s=RBRTE\&f=A>. Acesso em: 19 nov. 2016.

. Oil and natural gas sales accounted for $68 \%$ of Russia's total export revenues in 2013. Today in Energy. 23 Jul. 2014. Disponível em: < https://www.eia.gov/todayinenergy/detail.php?id=17231>. Acesso em: 12 abr. 2017.

. Russia looks beyond West Siberia for future oil and natural gas growth. Today in Energy. 19 Sept. 2014. Disponível em: < https://www.eia.gov/todayinenergy/detail.php?id=18051\#>. Acesso em: 10 abr. 2017.

. U.S. FOB Costs of Crude Oil (Dollars per Barrel). Disponível em: < https://www.eia.gov/dnav/pet/hist/LeafHandler.ashx?n=PET\&s $=I 000000004 \& \mathrm{f}=\mathrm{A}>$. Acesso em: 19 nov. 2016.

UKRAINE and Russia reach gas deal. BBC, 4 Jan. 2006. Disponível em:

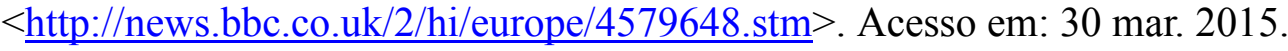


UKRAINE crisis: Transcript of leaked Nuland-Pyatt call. BBC, 7 Feb. 2014. Disponível em: < http://www.bbc.com/news/world-europe-26079957> . Acesso em: 16 mar. 2017.

UKRAINE rivals seek end to crisis. BBC, 27 Nov. 2004. Disponível em: < http://news.bbc.co.uk/2/hi/europe/4045449.stm>. Acesso em: 16 mar. 2017.

VAVILOV, A.; TROFIMOV, G. A Struggle for Pipelines: Gazprom's Attempts at Strategic Expansion in the "Near Abroad". In: Gazprom: An Energy Giant and its Challenges in Europe. Palgrave Macmillan, 2014, p. 105-139.

VERNON, R. Sovereignty at Bay: the Multinational Spread of U.S. Enterprises. New York: Basic Books, Inc. 1971.

VICTOR, D.; HULTS, D.; THURBER, M. Oil and Governance: State-Owned Enterprises and the World Energy Supply, 1st ed., Cambridge University Press, Cambridge, 2012.

VICTOR, D. National Oil Companies and the Future of the Oil Industry. Annual Review of Resource Economics, v. 5, p. 445-462, 2013.

VICTOR, N.; SAYFER, I. Gazprom: the struggle for power. In: VICTOR, D. G.; HULTS, D.; THURBER, M. C. (Ed.). Oil and Governance: State-owned Enterprises and the World Energy Supply. Cambridge University Press, Cambridge, 2012, p. 655700 .

WAGSTYL, S. Merkel sharpens attack on US sanctions against Russia. The Financial Times, 16 Jun. 2017. Disponível em: < https://www.ft.com/content/6fbafa0c-528e-11e7-bfb8997009366969 >. Acesso em: 16 ago. 2017.

WALTZ, K. Theory of International Politics. Berkeley: Addison-Wesley Publishing Company, 1979.

WASSERRAB, J.; DAMASCENO, M. Estatal russa Gazprom inicia construção de gasoduto estratégico no Báltico. Deutsche Welle, 9 abr. 2010. Disponível em:< http://dw.de/p/Mrj4>. Acesso em: 27 jul. 2014.

WEGREN, S.; HERSPRING, D. After Putin's Russia: Past Imperfect, Future Uncertain. New York: Rowman \& Littlefield Publishers, 2009

WEISS, M. The Corleones of the Caspian. Foreign Policy, 10 Jun. 2014. Disponível em: $<$ http://foreignpolicy.com/2014/06/10/the-corleones-of-the-caspian/ > . Acesso em: 13 jun. 2016.

WHY Putin pulled the plug on South Stream project. Russia Today (RT), 3 Dec. 2014. Disponível em: <https://www.rt.com/business/211023-eu-south-stream-putin/>. Acesso em: 22 nov. 2015.

WILCZEWSKI, W. The Big Gas Troika: A Lot of Hot Air. Journal of Energy Security, 14 Dec. 2008.2 Disponível em:

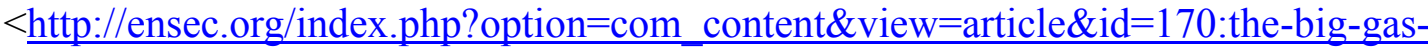


troika-a-lot-of-hot-air\&catid=90:energysecuritydecember08\&Itemid=334>. Acesso em: 11 jun. 2016.

WOLF, C. Drivers of Performance Change during Privatization. Cambridge: University of Cambridge, Judge Business School, 2008.

YERGIN, D. The Quest: Energy, Security, and the Remaking of the Modern World. New York: Penguin Books, 2012. 1991.

The Prize: The Epic Quest for Oil, Money \& Power. New York: The Free Press,

YIN, R. Estudo de Caso: Planejamento e Métodos. 3 ed. Porto Alegre: Bookman, 2005.

YOUNGS, R. Foreign Policy and Energy Security: Market, Pipelines and Politics. In: BIRCHFIELD, V.; DUFFIELD, J. (Ed.). Toward a Common European Union Energy Policy. New York: Palgrave Macmillan, 2011, p. 41-60.

ZHEBIT, A. A Rússia na ordem mundial: com o Ocidente, com o Oriente ou um pólo autônomo em um mundo multipolar? Revista Brasileira Política Internacional 46 (1), 2003, p. 153-181.

ZHUKOV, Y. Trouble in the Eastern Mediterranean Sea. Foreign Affairs, 20 Mar. 2013. Disponível em: <https://www.foreignaffairs.com/articles/cyprus/2013-03-20/troubleeastern-mediterranean-sea $>$. Acesso em: 19 mar. 2017.

ZUBOK, V. A Failed Empire: The Soviet Union in the Cold War from Stalin to Gorbachev. Chapel Hill, NC: University of North Carolina Press, 2007. 